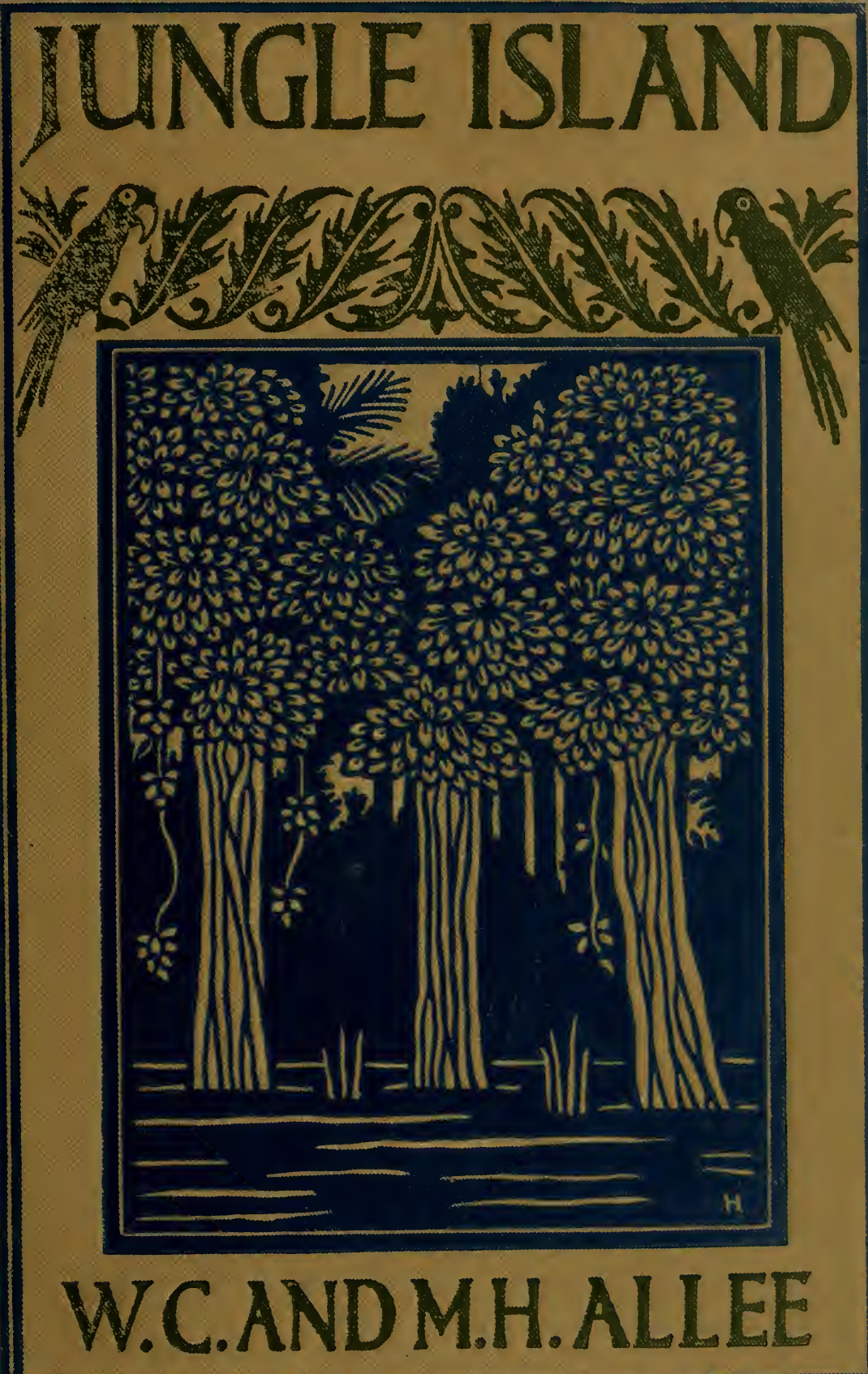





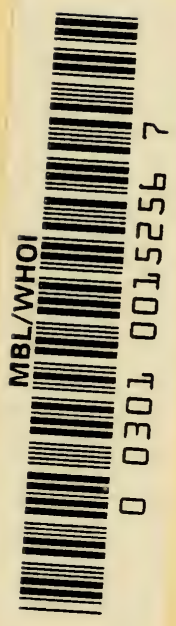




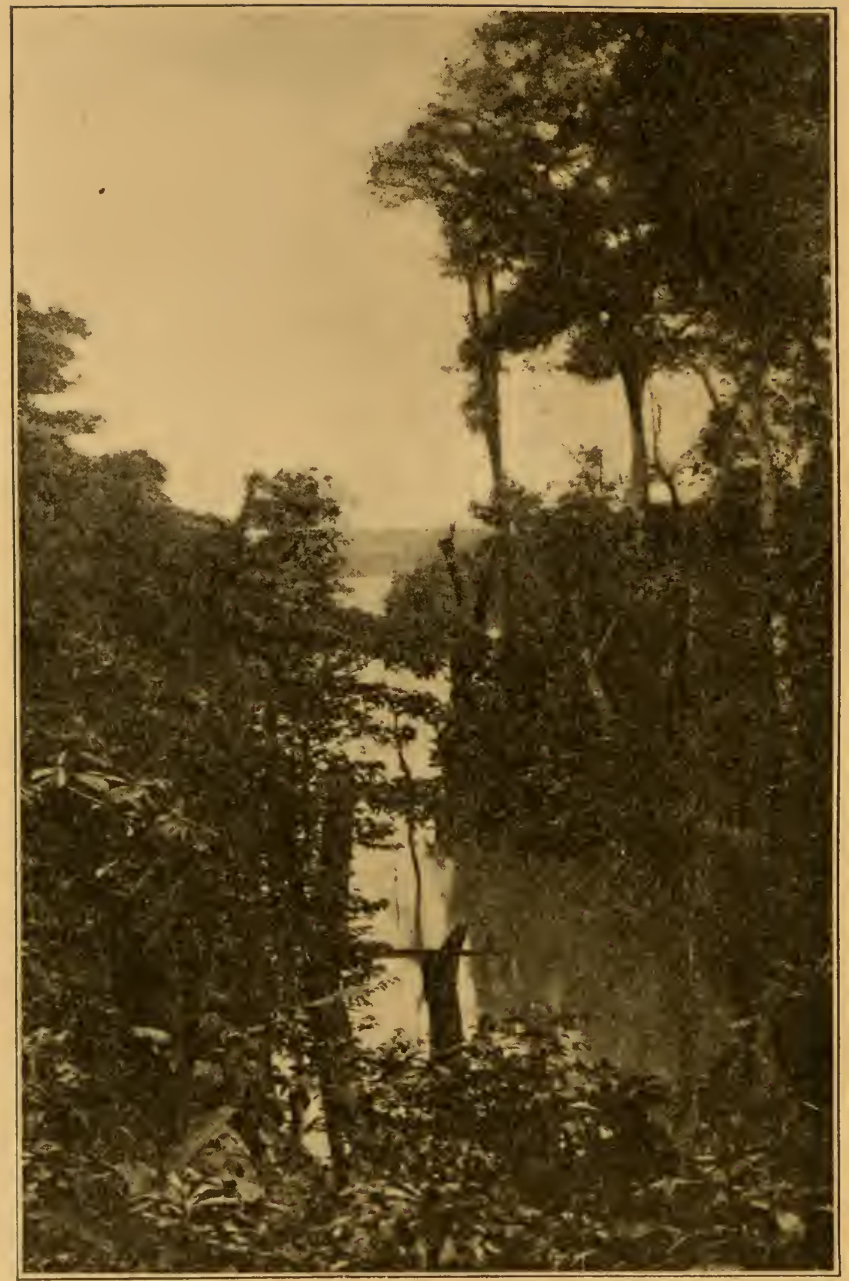

Photograph by Lutz

The inlet from the island shore 


\section{JUNGLE ISLAND}

By

WARDER C. ALLEE

Associate Professor of Zoölogy, University of Chicago

and

MARTORIE HILL ALLEE

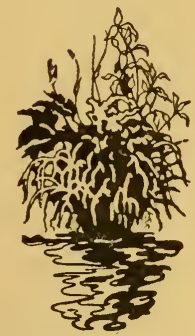

RAND MCNALLY \& COMPANY 
Copyright, 1925, by RAND MONALLY \& COMPANY

All rights reserved

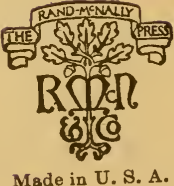


To

IUaxdex Alllex,

A good field companion,

$$
\text { I9I3-I923 }
$$





\section{THE CONTENTS}

The Preface . . . . . . . . . . . Pax

Old Roads to a New Island . . . . . . I

From Ancon to the Island . . . . . . 20

My Tree . . . . . . . . . . . 38

The Clever Family of Ants . . . . . . 54

Termites, the Destroyers . . . . . . . 68

Spiders and Their Relatives . . . . . . 89

Peripatus, the Most Interesting Animal . IO3

Snakes and Crocodiles . . . . . . . . 107

The Ancient Family of Lizards . . . . . I 23

Strange Birds . . . . . . . . . . . . . $\mathrm{I} 37$

Furry Animals . . . . . . . . . . . I59

The Conquest of the Mosquitoes . . ‘ . $\quad$ I79

MORE BOOKS . . . . . . . . . . . 195

Glossary . . . . . . . . . . . . . 197

Suggestions to Teachers . . . . . . . . . 205

The Index . . . . . . . . . . . . $2 \mathrm{II}$

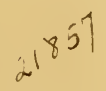




\section{A LIST OF MAPS}

Early trade routes to South America . . . . . 4 The Canal Zone . . . . . . . . . 11

The Panama Canal: Pacific entrance and profile view . 15

\section{A LIST OF FULL-PAGE HALF-TONE ILLUSTRATIONS}

The inlet from the island shore . . . . Frontispiece

A ship passing through Gatun Lake . . . . . 18

The island from the inlet . . . . . . . . 35

Spanish bayonet palm with termite nest . 36

The spike ladder . . . . . . . . . . 41

A stilt palm with termite nest . . . . . . . 69

Termite runways on tree trunk . . . . . . . . 72

Anteater feeding on termites . . . . . . . 82

Termite mound nest . . . . . . . . . 84

The home of the crocodile . . . . . . . . 119

Where the long-toed jacana walks on the lily pads . 140

The machete-cut trail . . . . . . . . 151

Where soldiers and mosquitoes lived together in old Fort

San Lorenzo . . . . . . . . . 180

Clean pared street in Panama . . . . . . . . 187

Drain-making by the American Sanitary Service 189 


\section{THE PREFACE}

Most of the books written for children about the tropics are purely romantic, and that has seemed a great pity to the writers of this little book. Every year, as disease is pushed back and as men understand better the conditions under which they can safely work near the equator, more and more rich territory is open to the overcrowded colder regions. Transportation and communication have at the same time become rapidly easier and cheaper. Many of the children who read this book will come to know the tropics from their own experience, and they will be happier if they have not too many ignorant prejudices or romantic dreams to set aside.

Further, even to the stay-at-home, there is great interest in the lives of plants and animals that have the whole year round in which to develop; in the substitution of a dry season for a northern winter; and in a country whose forests, streams, and hills are as yet largely unchanged by civilization.

And let us admit gladly that from the most scientific point of view there is still the glamor of romance in the tropics. The beauty of the golden-flowering tecoma tree, the absurdity of the great bill of the toucan, the drama of the long struggle between white men and yellow fever - these are as keenly fascinating when seen with wide-open critical eyes as ever they were in any legendary tale.

Our own experiences were made possible by grants from the University of Chicago and the Bache Fund 
of the National Academy of Science. The account set down here has been checked and often supplemented from the observations of more specialized writers, to all of whom we are most grateful.

We are indebted to Mr. Kenji Toda for making the drawings; to Mr. James Zetek, United States entomologist in the Canal Zone, Dr. F. E. Lutz of the American Museum of Natural History, Dr. Curt P. Richter of Johns Hopkins University, the United States Army Air Service, and the Field Museum for permission to use photographs taken by them. The manuscript was read and helpfully criticized by Miss Bertha Morris Parker, of the University of Chicago Elementary School.

Several authors and publishers have kindly allowed us to copy drawings from their books. We are indebted to the following: Cambridge Natural History, Organic Evolution by R. S. Lull, Vertebrate Zoölogy by H. H. Newman, Medical Zoölogy by W. B. Herms, all published by the Macmillan Company; Ants by William M. Wheeler, published by the Columbia University Press, and Social Life among the Insects, also by Dr. Wheeler, and published by Harcourt, Brace \& Company. 


\section{JUNGLE ISLAND \\ OLD ROADS TO A NEW ISLAND}

A narrow mountainous strip of land running nearly east and west joins North America to South America. It is called the Isthmus of Panama. Almost ever since the time when Columbus landed there, it has.been one of the great highways of the world.

Balboa, who struggled across the Isthmus through mountains, swamps, and jungles, not only found the Pacific Ocean. He brought back pearls and gold, and every Spanish explorer returned with news of the golden ornaments the Indians wore. The Spaniards wanted the gold for themselves. They took it away from the Indians, who could not protect themselves against the Spanish guns, and made the Indians bring more gold from the mines and treasure houses. Peru, on the western coast of South America, furnished most of the gold, but there were also pearls from the little islands off the coast, and furs from the animals that ranged the great forests.

But not even the most determined gold hunter could live on the yellow metal. It had to be sent back to Spain regularly to pay for the cargoes 
of European food and cloth, wine and weapons brought to Panama by the Spanish fleet. Roads must be made and guarded so that both gold and supplies would travel safely. The shortest way from Spanish ports to the west coast of South America lay, as you see on the map (page 4), over the Atlantic Ocean, across the narrow Isthmus of Panama, and south again by ship.

One road was a land- and water-way. Ships sailed up the Chagres River as far as they could go from the Atlantic side, and then loaded their cargo on pack trains to be driven by trail to the city of Panama on the Pacific Ocean. The Chagres River has been a most important river of travel for the last four hundred years, but probably it looked much the same to the Spaniards as the photograph (Fig. I) shows it today. The thick rain forest on its banks has been little disturbed.

Another road went all the way overland from one ocean coast to the other. The Spanish-built trails were called the "king's highways." They were about four feet wide and paved with stones picked up by the way, and they rambled in and out among the hills and streams wherever the going seemed easiest. Today parts of them still may be seen, but great trees have grown up through the rough pavement since the time when they were in constant use.

It was hard work to keep them clear even when they were being used all the time. The Isthmus 
is close to the equator, and in that part of the world, which is shown as the rainy tropics on the map, it is always warm and usually moist. Day after day the vines and bushes of the jungle stretched their fast-growing branches across the

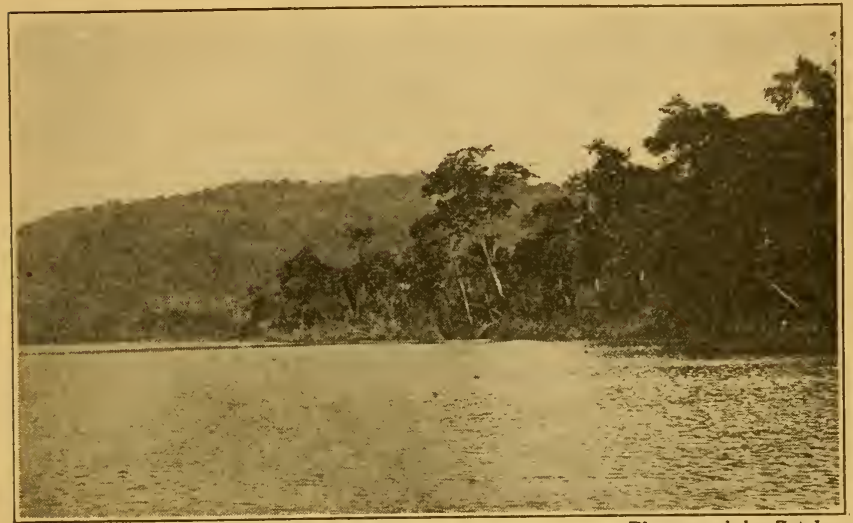

FIG. I. Bank of the Chagres River

trail, and some one was continually busy cutting the tangle back so that the loaded pack trains could pass.

When the narrow trails were kept open, still the men and mules suffered. Runaway negroes, brought over from Africa to take the place of the unwilling Indian slaves, hid in the thick bush and robbed the pack trains. And the Spaniards were afraid of the few Indians left in the forest, as they had reason to be. To this day the Indians of the Isthmus distrust white men so. heartily 


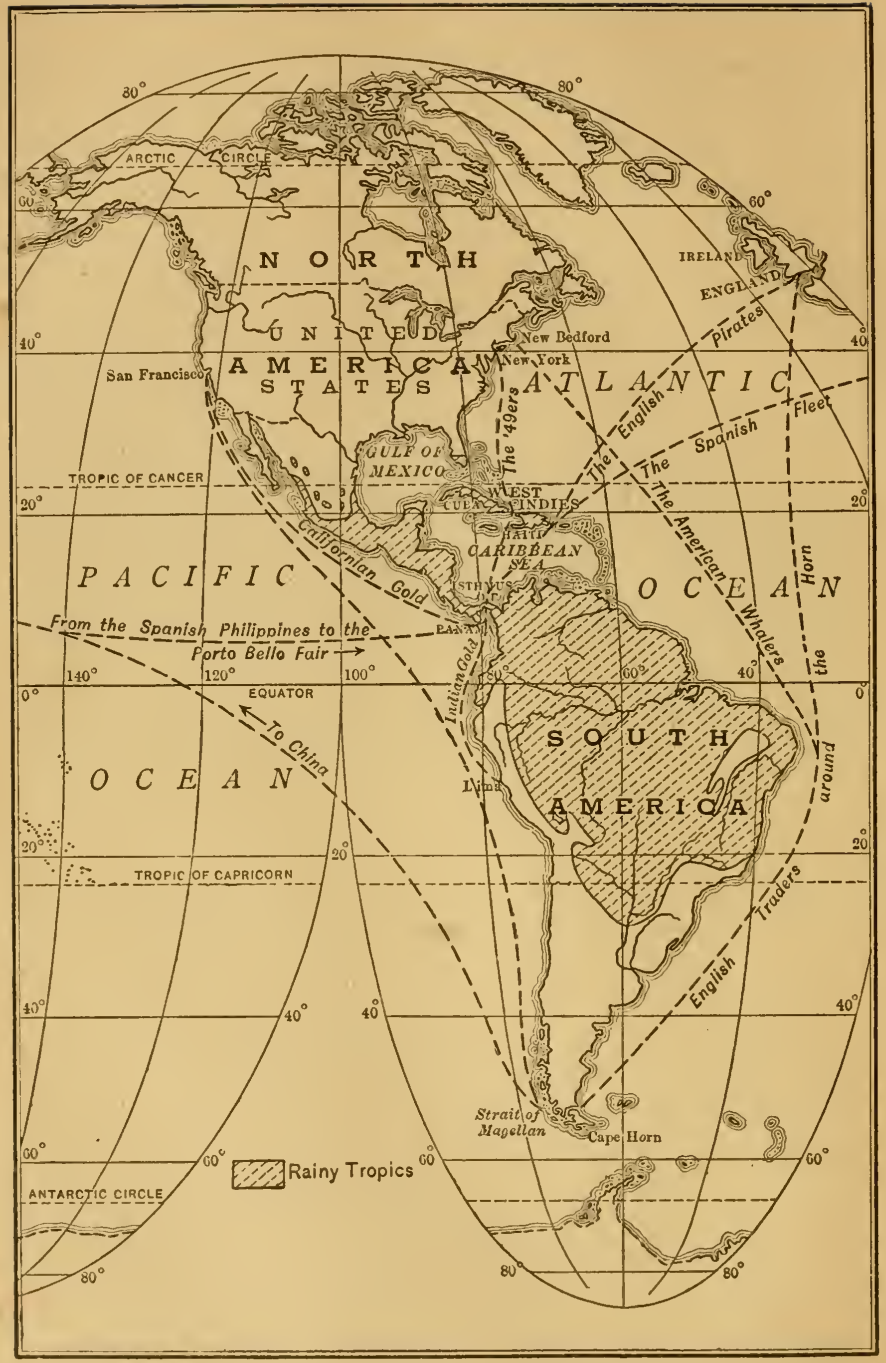

FIG. 2. Early trade routes to South America 
that they will hardly let one stay in their villages overnight.

Even on the most peaceful trips the men were terribly bitten by small jungle pests. Little brown ticks waited on every leaf for a chance to fasten themselves on man or beast and suck his blood. Clouds of hungry mosquitoes rose from the wayside pools. The men sickened and died of malaria and yellow fever. Yellow fever was a disease no European had ever heard of before America was discovered.

Big boa constrictors rustled through the leaves, and painted, poisonous little coral snakes lay under rotten logs. The natives frightened the Spaniards with stories of other jungle animals which were seldom seen. Sometimes, however, they did catch sight of the green eyes of a "tiger cat" shining in the camp-fire light, or heard in the distance the deep howling of an animal the natives said was a monkey, but which sounded more like the roaring of a great bull.

It is no wonder that the Spaniards, even while they were building their first roads four hundred years ago, tried to work out some easier and safer method of travel. They puzzled over some way of making a canal that would join a river on the Atlantic side to a river that ran into the Pacific Ocean, but their plans were too expensive to carry out. They were obliged to stick to the king's highways and the Chagres River. Away 
from these they were afraid to venture, and tales of the remarkable plants and animals to be found in the depths of the jungle grew bigger every year.

Their cities were built along the coast, and many of them were very rich. At Porto Bello, a beautiful harbor on the Atlantic side, there was a fair like a great market twice a year. The streets of the town were piled with wedges of silver waiting for the Spanish fleets to come with goods for exchange. Merchants came to this fair across the sea from the Philippines and up and down the Pacific coast of the Americas. They exchanged their precious wares and hurried away as fast as they could, for the air of lovely Porto Bello was said to be unhealthful, and many caught malaria and yellow fever there.

This was in the days when Spain had at sea in her fleet many high galleons bearing her flag, her gold, and her goods. But England was growing strong at sea, too, and trying her strength against Spain. She built up her navy and she encouraged English pirates so long as they brought home Spanish treasure.

Stories of Porto Bello in fair time were enough to make the mouth of an English pirate water. One successful raid on a city like that and he and his crew would be rich for life. Henry Morgan left his ships and struck out across land to old Panama, an even richer prize than the 
cities on the Atlantic side and not so well guarded. His men nearly starved to death on the way, although there were animals on every side that would have made good eating, had the Englishmen known it. But they did reach Panama, took the city, and carried off much gold. For this and other raids Henry Morgan was made an English knight.

Other pirates were encouraged by Morgan's success. They attacked at sea, so that Spanish ships never sailed alone. They made the Chagres River unsafe for valuable goods, and the king's road from Panama to Porto Bello was finally ordered to be used only at fair times, when the merchants and mule trains traveled with an escort of Spanish soldiers.

When after two hundred years peace came between the two countries, Spanish trade and Spanish power were broken. At that time the Isthmus was no longer important to Spain or to any other country. All the stored-up gold of the Indians had been seized and sent back to Europe. The gold left in the old mines and the sand of the stream beds was so thinly scattered that white men would not bother with it. No one on the Isthmus was rich enough to buy cloth and wine from Spain. English traders and American whalers bound for the Pacific sailed south around Cape Horn by the route shown on the map (page 4). The long trip by sea was 
easier and cost less than packing shiploads across the Panama hills. Except where the natives kept a path worn, the king's highways went back to jungle.

It was gold that opened the roads again. In I849, another hundred years later, gold was discovered in California, and eastern Americans who heard the news were in wild haste to reach it. They might go in three ways: in sailing ships around the Horn as the whalers had done, or across the untraveled plains and mountains of western United States, or by the Forty-niners' route shown on the map, south to Panama, across by river and boat, and up the Pacific coast by ship to California. This last way usually took less time for passengers than either of the others, and it became once more the road of the gold hunters.

Just as in the time of the first Spaniards, men began to plan for a canal that would make an easy water highway across the Isthmus. Many attempts were made up and down the coast in different places, but all failed. The plan that seemed for a time most likely to succeed was that of a French company which began digging in I88I. They decided to cut through the hills from Colon to Panama along the line where the Canal goes today, and work has never stopped entirely from that day to this, though the French themselves were not able to finish it. 
It was not only that they had too little money for such a tremendous task. Their trouble was worse than that. They could not keep men well enough to do the work. The workmen whom they brought over from France and Spain and down from the United States fell sick and died from malaria and yellow fever just as newcomers had always done on the Isthmus. No one had learned what caused these diseases or how to prevent them.

In 1904 the United States bought the rights and the supplies of the French company, and ten years later the old dream of an ocean-to-ocean waterway had come true. The canal that "divided the land, united the world," was finished.

The Americans were good engineers, and they were fortunate enough to know how to treat malaria and yellow fever. For two or three years some American physicians had known that both diseases are carried by certain kinds of mosquitoes. Working as quickly as they could, the Americans killed off the mosquitoes near the Canal, destroyed the places where they could lay their eggs, and screened the houses where the workmen slept at night. Within a few months the Canal Zone, once called the unhealthiest spot in America, became known as the healthiest place in the world.

The French had at first intended to make a sea-level canal. They expected to cut down 
through the hills until the salt water of the two oceans met in a deep channel through which ocean ships could sail without stopping. This plan took so much expensive digging that they decided instead to build a canal with locks to lift ships up to a higher channel. This is the plan now used by the Americans in the Canal.

From Colon on the Atlantic side a sea-level canal was shoveled out through the low country seven miles to Gatun Locks. You can see this on the map of the Canal Zone, as well as another seven-mile sea-level canal on the Pacific side below Miraflores Locks. Joining the two is a great man-made fresh-water lake, whose surface is about eighty-five feet above sea level.

Part of the bed of this lake is the valley of the Chagres River. Where the river turns sharply away into the hills at Gamboa, as the map (page I I) shows, so that its valley can no longer be used, the engineers have cut straight through to Miraflores Locks a long, narrow passageway.

Along this nine-mile stretch the engineers had much trouble. The rock and clay of the hillsides were soft, and when they were disturbed by digging they had an unexpected way of slipping down overnight into the cuts that were being made, burying the tools and leaving all the digging to be done over again.

The hills were covered, not only with a tangle of plants, but also with many feet of fine red 


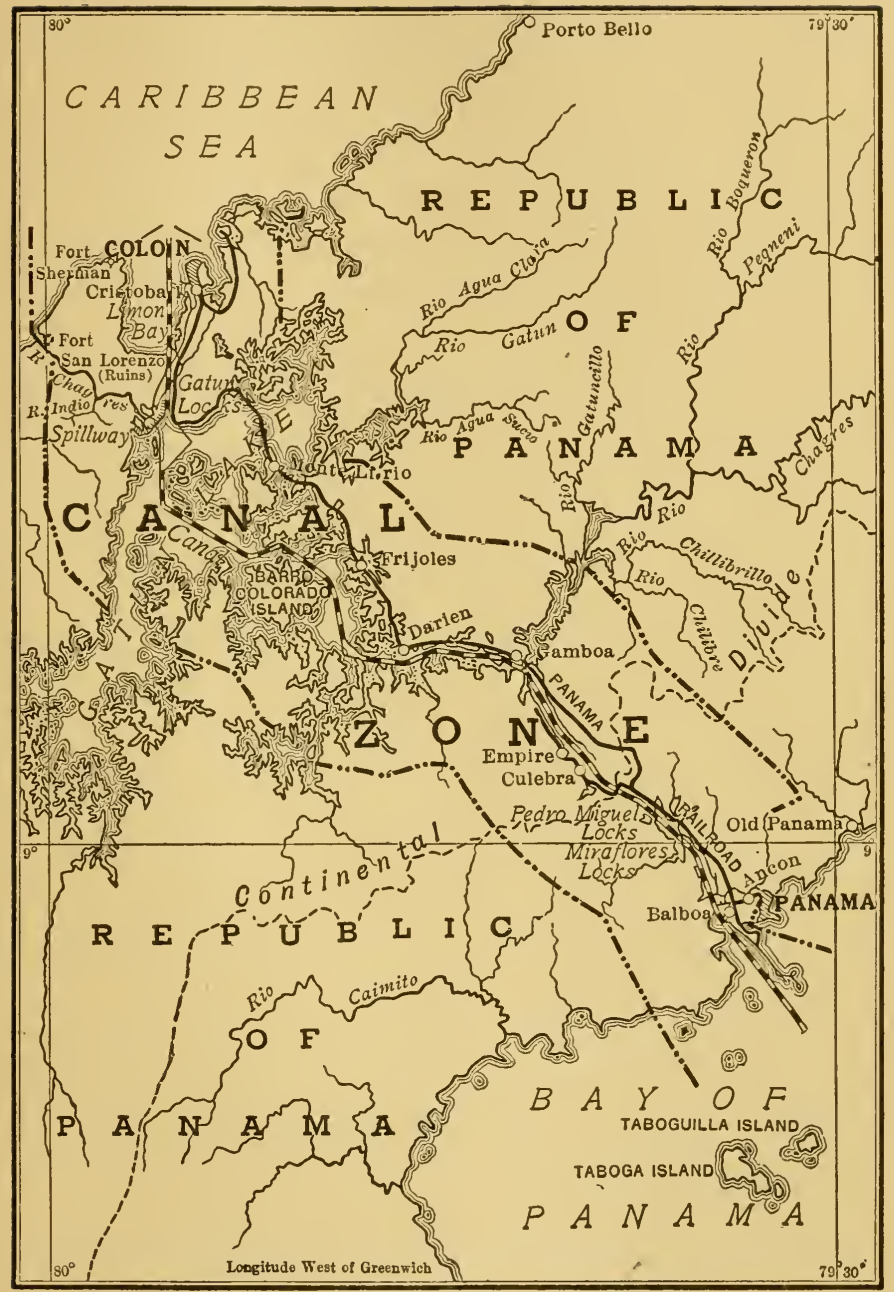

Fig. 3. Canal Zone 
earth that hid the rocks underneath, so that it was impossible to tell how long to expect them to keep sliding down into the Canal. The engineers sent for a geologist, a man who had studied rocks and knew their history, to come down from the United States and help them decide which were solid enough to make safe canal banks and which could not be trusted.

The geologist studied the cut hillsides and bored down to rock in other parts of the Isthmus. He was able to give advice to the canal builders, so that the Canal could be safely made. He found, too, stories of the Isthmus long before the Spaniards or the Indians came.

The rocks showed that some of them had first been poured out from volcanoes, red-hot and soft as molasses. After they had cooled, the wind and rain had weathered them into smaller pieces, the sea water had poured over them and left the skeletons of little sea animals strewn among them, and the rivers had washed valleys through them again and again.

The rocks showed plainly that the Isthmus has not always been solid land as it is today. Often it has sunk under the sea until its mountain tops were only a chain of islands between North and South America.

This is one reason why the South American animals are so different from those in North America. For many thousands of years at a 
time they could not cross from one land to another, and in those years when they could not mix together they grew to be less and less alike. In North America the old camel family died out, while in South America the same family grew into the llama and the guanaco. In South America the rodent family flourished in many sizes and shapes. In North America we think of a rat as a large rodent, but on the other side of Panama some rodents grew four and five feet long. There came to be very few kinds of deer in South America. The catfishes are much more important among the water animals than they are farther north. Running birds, somewhat like ostriches, live wild in South America, and opossumlike animals, that carry their young in pouches, are more common there than with us.

It seems quite certain from the story of the rocks that the Isthmus of Panama was under water the last time many thousands of years ago. If Columbus had lived so long ago he might have found his waterway to India then; but, so far as we know, there were at that time no men on the earth yet. The land has not stayed at the same height since the last ocean connection was broken. Sometimes it rises, sometimes it sinks, and again it stands quiet long enough for the ocean to build up great beaches. Judging from these old beaches, the land has been slowly rising for the last thousand years at the rate of three feet in a 
century. No one can guess how long it will keep on rising. It is just as likely that some day it will begin to sink once more.

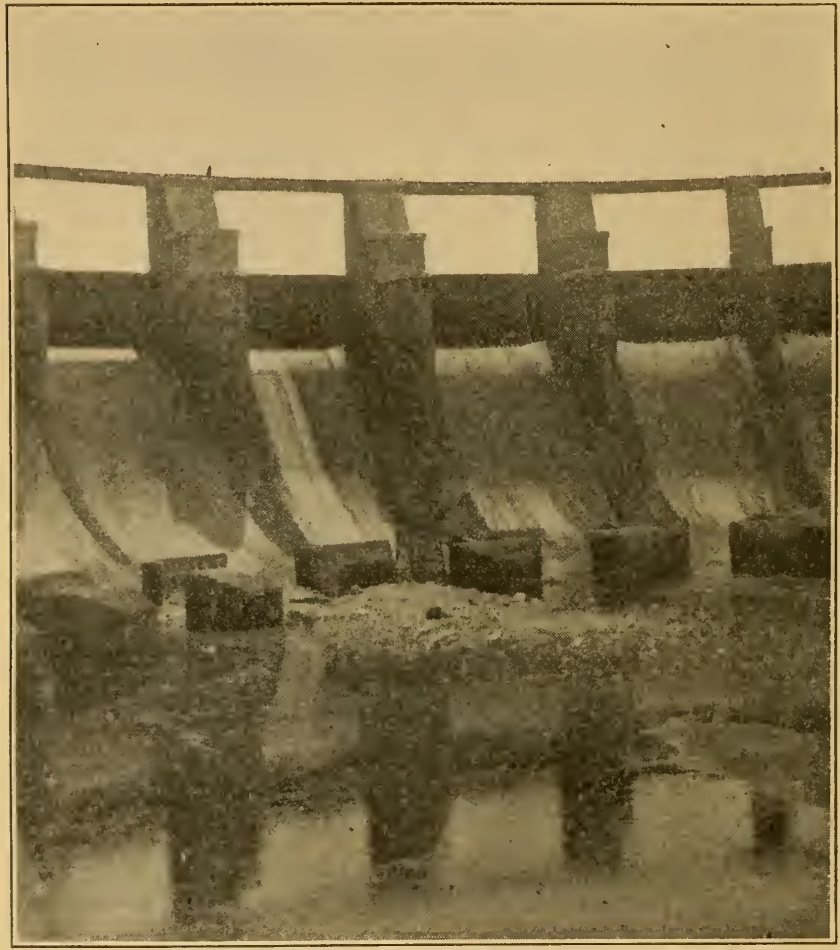

FIG. 4. The spillway of the Gatun Dam

The engineers who had made the Canal worked much faster than the earth forces which had for millions of years lifted and lowered the land in their own way. The men had dams and a swift 

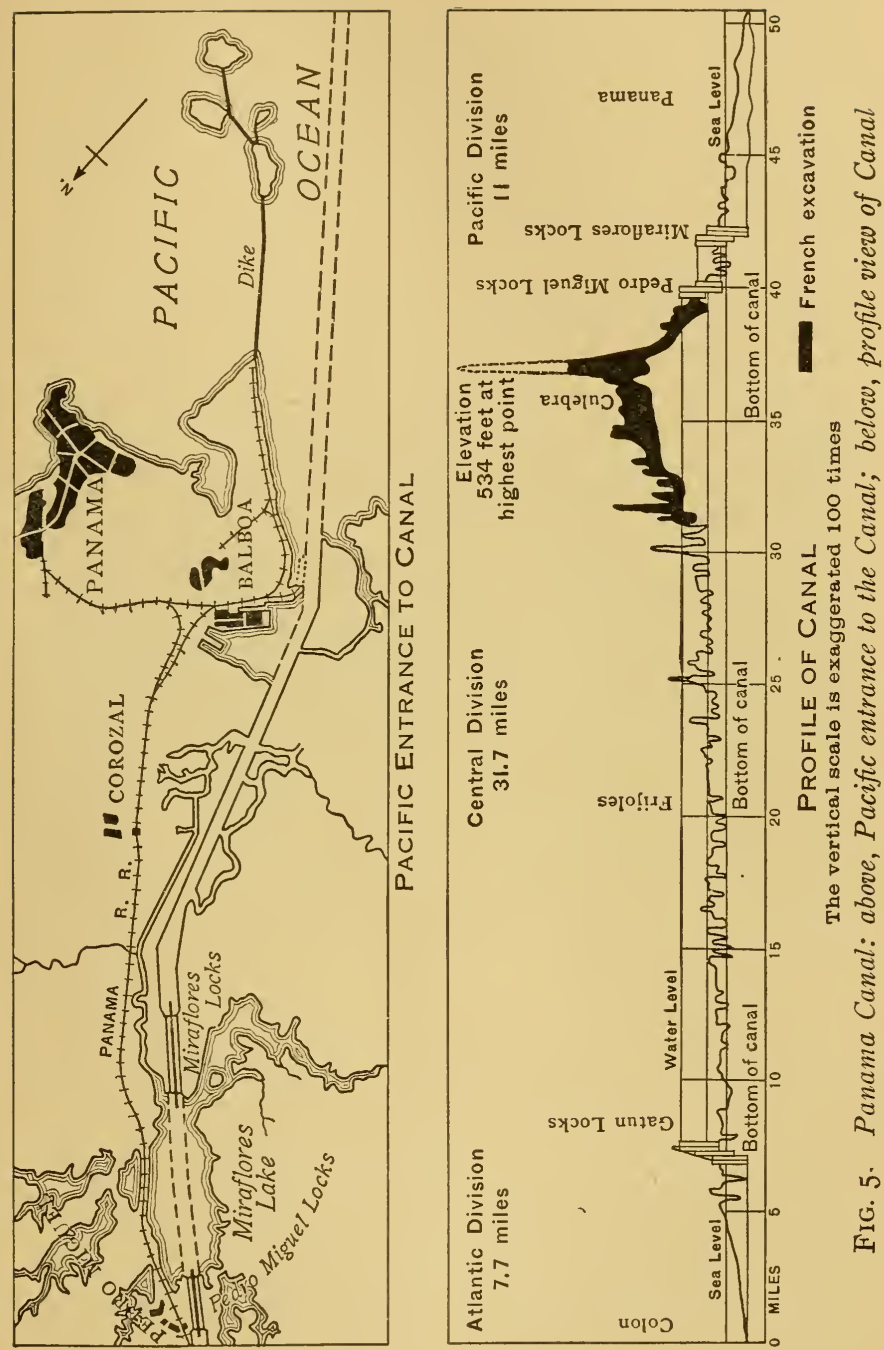
tropical river to help them flood the Chagres valley and make Gatun Lake. At Gatun they built a wide, gently rolling hill that is so broad and grassy that it does not look like a dam at all. This stands.straight across the path of the Chagres River. When it was finished, it caught and held back the river waters. The water rose higher and higher as the heavy summer rains fell, until it reached at last the top of the locks and the spillway (Fig. 4). When it stood eighty-five feet above sea level, the extra water was allowed to run over the spillway and off down the old river bed to the Atlantic.

While the waters of the new lake were rising, there was a long time of moving among the mysterious animals that lived in the great forests of the drowned Chagres valley. The people of the few native villages the lake would cover had been warned in plenty of time and given new land high and dry. Nobody warned the animals. Every day as the water rose they moved back a little higher, and often in the morning they found they had been cut off in the night from old hunting grounds and play places. Most animals can swim, but not many of them like to, especially when there are crocodiles in the water. They preferred to go higher in the hills. Even the sloth, which hates to move at all, had to sling himself from one branch to another as the water rose. 
When the lake was full, many animals found themselves stranded on hilltops that now were islands in the lake, and there they were obliged to stay, as securely penned in as the bears in zoölogical gardens.

The largest of these islands (Fig. 6) that once was a hill is almost in the middle of Gatun Lake,

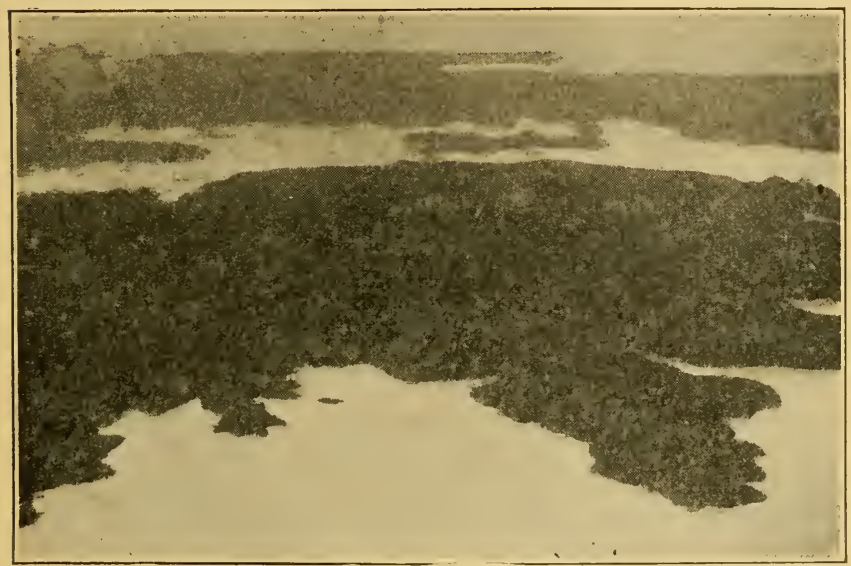

Courtesy of U. S. Air Service

Fig. 6. Barro Colorado Island from an airplane

easily seen on the map of the Canal and passed by every ship that steams through (Fig. 7). There are about six square miles of it, covered with heavy forest and as well stocked with animals fleeing from the water as a tropical Noah's Ark.

In 1923 the governor of the Canal Zone decided that this island should be set aside for a forest preserve. It is known as Barro Colorado, which 


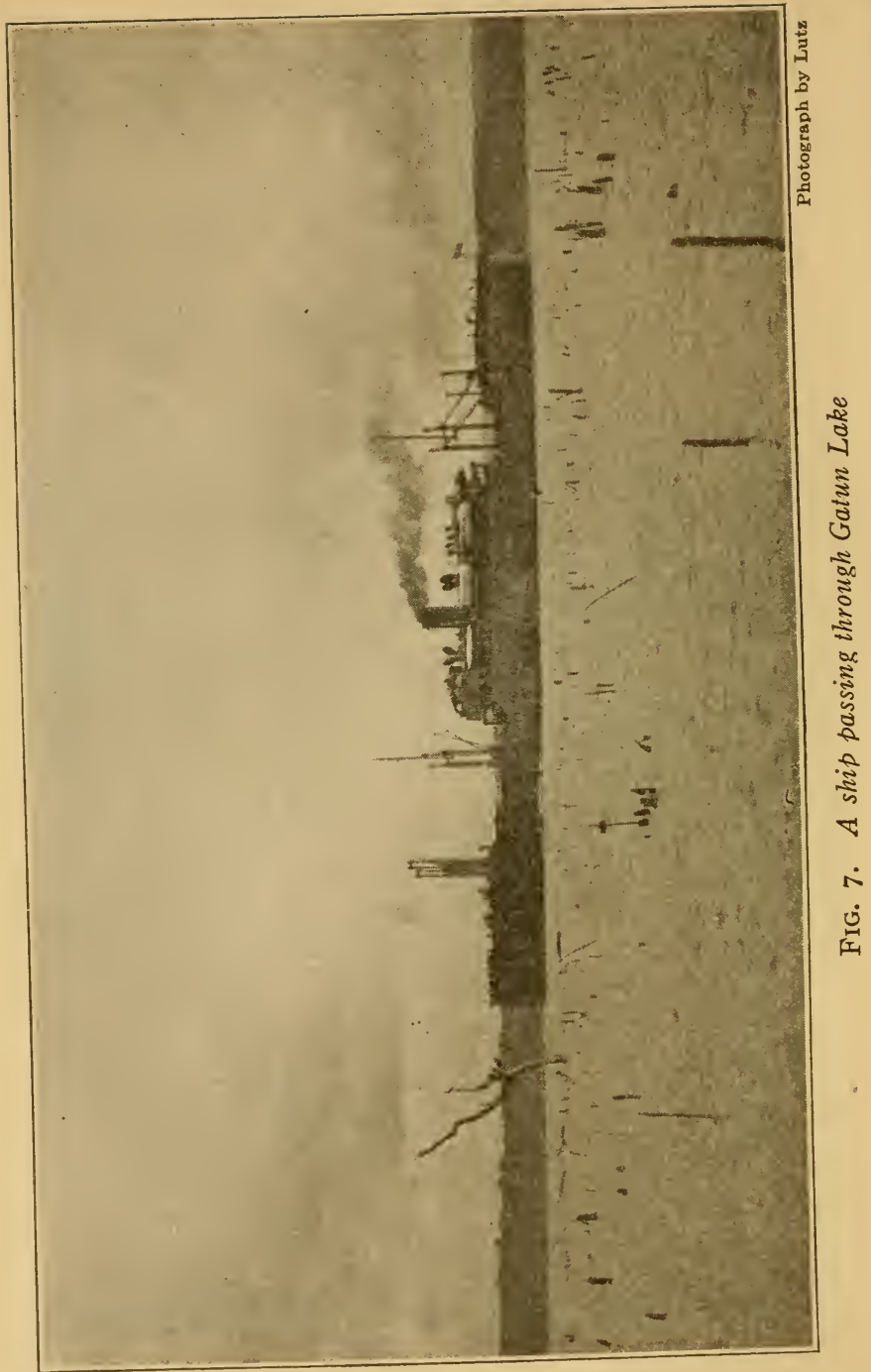


means in English "red clay," from the color of the soil. We have called it Jungle Island. No animals are to be hunted there, nor any trees cut, and people are invited to come and find how animals really grow and behave in a tropical forest.

The Indians who mined the gold, the Spanish explorers who came hunting it, and the English pirates who followed them, the Forty-niners who opened the old roads again, the French who tried to build the Canal, and the Americans who succeeded - these were the people who had made the paths that led me to Barro Colorado in the winter of 1924 .

This little book tells about Jungle Island and some of the animals I found there. The brave old explorers would be surprised and amused at such a strange winter's work; but then they never knew how interesting tropical animals can be. 


\section{FROM ANCON TO THE ISLAND}

B-r-r-r! B-r-r-r! The alarm clock was saying over and over that it was half-past five of a cool, dark January morning in Panama. Although it is only a few hundred miles north of the equator, we never found a night when we were not grateful for our blankets. Ancon, built high on the shoulder of a hill overlooking the city of Panama, sometimes has a temperature of sixty-five degrees at night, and that, in the tropics, makes one shiver. Ancon, with its screened houses (Fig. 8), its American supplies, and its American hospital, was my headquarters. Already, in the few days I had spent on the Isthmus, I had worked out a schedule that took me from Ancon to Barro Colorado in the shortest time.

First came a cold shower bath in the big bathroom that the United States government provides in all the airy houses where Canal Zone workers live. My toes touched something round and smooth on the floor, and I found a crocodile egg lying on the grating of the shower-bath drain. Santiago had given me that egg the day before, and at night when I turned out the electric light it was lying on the table by my bed. Some animal, perhaps a rat, but more likely a harmless snake, had tried to carry it off down the drain in 
the night, and found it too large to pull through the iron grating.

I carried the egg back to my room and hurriedly dressed in the same heavy cotton clothes I wear comfortably while tramping through the Indiana

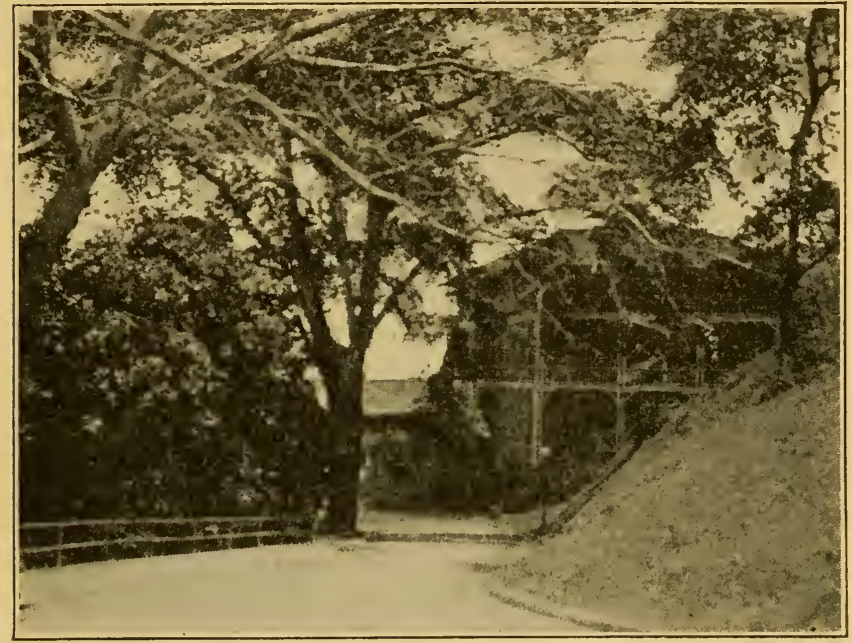

FIG. 8. Bachelors' quarters in Ancon

dunes in the springtime. With my khaki trousers I put on leather puttees and heavy boots, which help to keep off ticks, znd might have saved me a snake bite in case I met a poisonous snake. I may add that $I$ never did meet a poisonous snake in the jungle. I put on a tie and a coat because white men are expected to wear them in that part of the world, and when I was thus dressed up I completed my costume with a limp cloth 
hat much more useful than beautiful. I found no need of the cork helmets often thought necessary. Across the Bay of Panama the east was growing faintly lighter. It was always a temptation to stand and watch the spectacle of the sun rising over the Pacific Ocean, which gives one a very odd feeling unless he studies carefully the map of the Isthmus. But there was not much time for that. I slung over my shoulder the knapsack holding my collecting outfit and my lunch, and

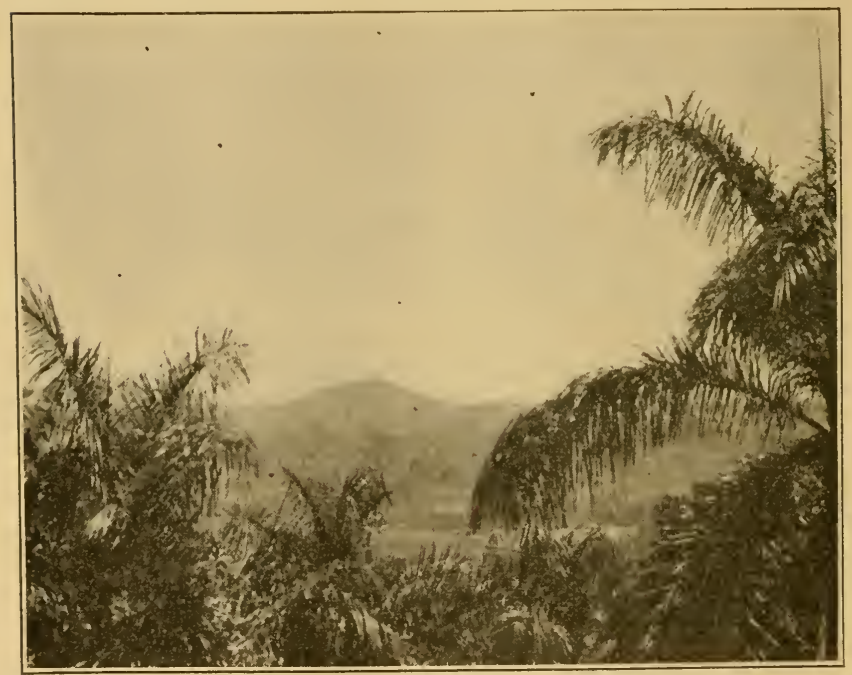

FIG. 9. Royal palms overlooking the plains of Panama

was away down Ancon Hill to the restaurant, under an avenue of rubber trees and palms, past two solidly built blocks of hospital. 
The American restaurant (Fig. Io) is big and clean, and little breezes blow through it pleasantly, sending the white paper napkins scurrying across

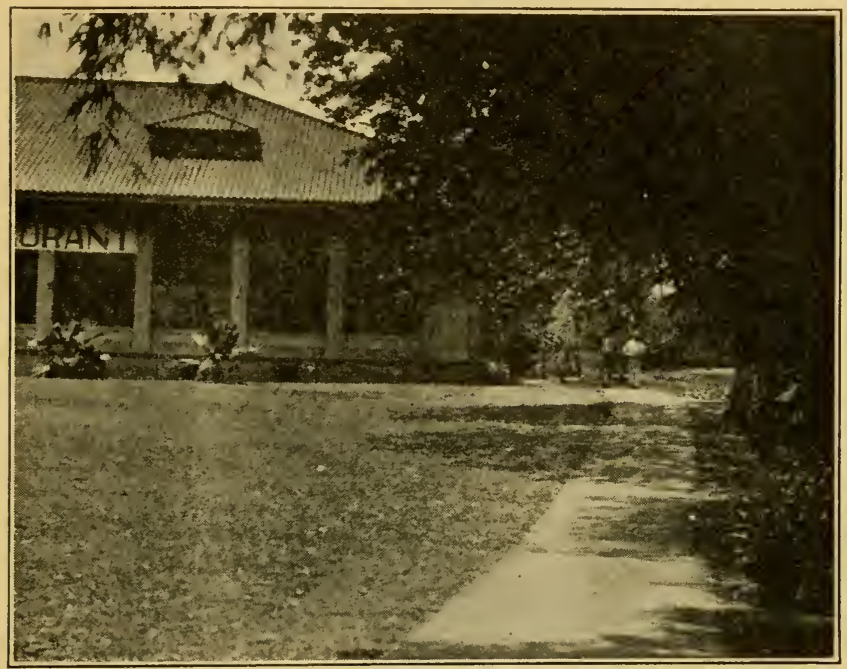

FIG. Io. The American restaurant in Ancon

the cement floor. The breakfast is much the same that any American cafeteria would serve in midsummer. The oranges are peeled like apples, with only a button of rind left at one end to hold while the rest is eaten. The melon that looks and tastes much like a cantelope is really a papaya, which grows on a tree instead of a vine. In the photograph (Fig. II, page 24) the porcupine is posing on the crown of one of these papaya trees. 
At the restaurant I found Molino, a tall, handsome Panamanian who was assisting the Canal Zone entomologist in his study of insects. Molino

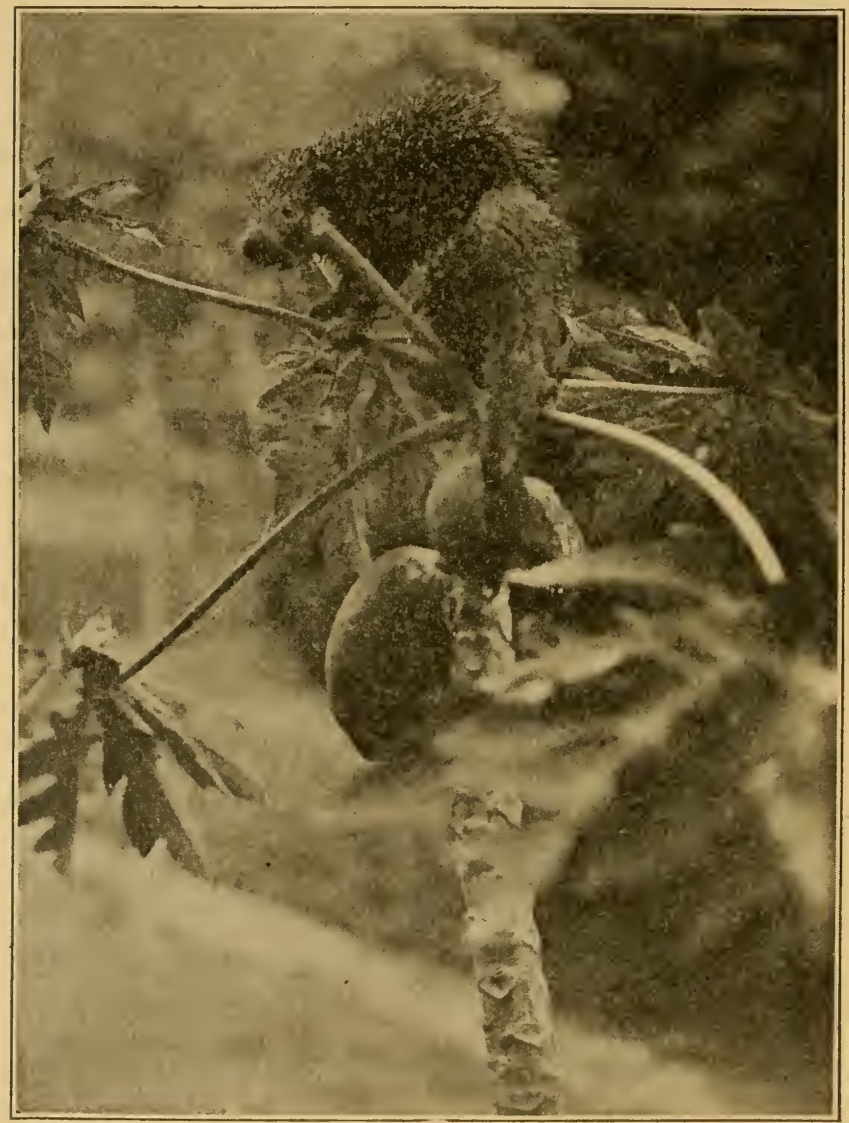

Photograph by Zetek

FIG. II. Porcupine in a papaya tree 
did not worry about the dignity of his clothes on these trips. He went hatless and coatless and carried his lunch in a brightly colored twine bag over his shoulder, in the comfortable fashion of the humblest workers. He was educated at the University of Panama to be a lawyer, but he knew a great deal about plants and animals, too, and I was always glad to have his company.

After breakfast we made our way in the full light of a new day past the cool and beautiful American school building, and along a little walk that runs up steps and down between houses to the more thickly built-up streets of Panama and the modern railway station. The morning Star and Herald, printed both in Spanish and in English, cost us a nickel from a little brown newsboy. We showed our passes to the friendly conductor, who already knew my face, and climbed aboard the waiting train.

The Panama railway is short but important since it is the only road open all the way across the Isthmus. The Canal does very well for ocean liners and battleships, but it is far too slow and expensive for commuters. All kinds of people take this early morning train. Chattering tourists run over for a day's sight-seeing in Colon. Plantation owners go out to oversee work in the bananas. Sometimes there are sleepy actors from the vaudeville theaters. Children ride to school. The quietest passengers are the Canal 
Zone workers. Negroes usually take another car on which they do not pay so much for their tickets.

We pulled out of the station promptly on time, swinging round a half-circle that brings the train to the Balboa station near the Pacific end of the Canal. After that the railway line keeps fairly close to the Canal as it runs north to the Atlantic Ocean. Already the ships were moving through Miraflores Locks. Beyond the locks we looked anxiously down at Miraflores Lake to see if the wind was up yet. If the wind were blowing strongly, we knew we should get well drenched going across the much bigger Gatun Lake to our island.

Soon came Pedro Miguel Locks-Americans call them Peter M'Gill - then Culebra Cut, which still shows the red and yellow clay and the rocks that told their stories to the geologist. Empire was next. Once it was the Canal headquarters and the busiest town on the Canal Zone, but now that the Canal is finished and the engineers have moved away it is sleepy and weatherbeaten. Farther along at Gamboa we crossed the pretty Chagres River where it joins the lake it helped make. In the dry season it is a quiet-looking stream, but at its times of high flood it brings down whole tree trunks, which must not be allowed to drift out into the Canal in the way of the big ships. 
Nearly all the way from Panama we had come through high hills. Along the railroad they have been cleared of the heavy jungle bush, and herds of cattle graze over them just as they do in the dairy country of the United States. Corozo palms and the great leaves of banana plants have sometimes reminded me that I was still in the tropics.

Halfway across the Zone you will find, if you have been following us on the map, our station, Frijoles, which we reached after an hour's travel. Frijoles, if you are interested, means just "beans." But it is not beans for which the tiny negro village is noted, but its bananas, which are the finest in the country. The gold of bananas is now the gold of Panama, for which fortune hunters toil.

A huge dugout canoe, piled high with green bunches of bananas, now lay at the rickety wharf, waiting to be unloaded into one of the empty freight cars standing on the railway siding. We looked at the load with interest, knowing from past experience that if a bunch among them had begun to turn yellow we might have it for the asking. Bananas ripen so fast that only the green ones will not spoil in the ten days between Frijoles and New York.

On the cinder platform waited John English (Fig. I2), the friendly and intelligent negro who helped me to find workmen when he was not busy 
overseeing his cattle, his alligator-pear orchard, or some other venture. He spoke very good English, Spanish, and a little "African," whatever that

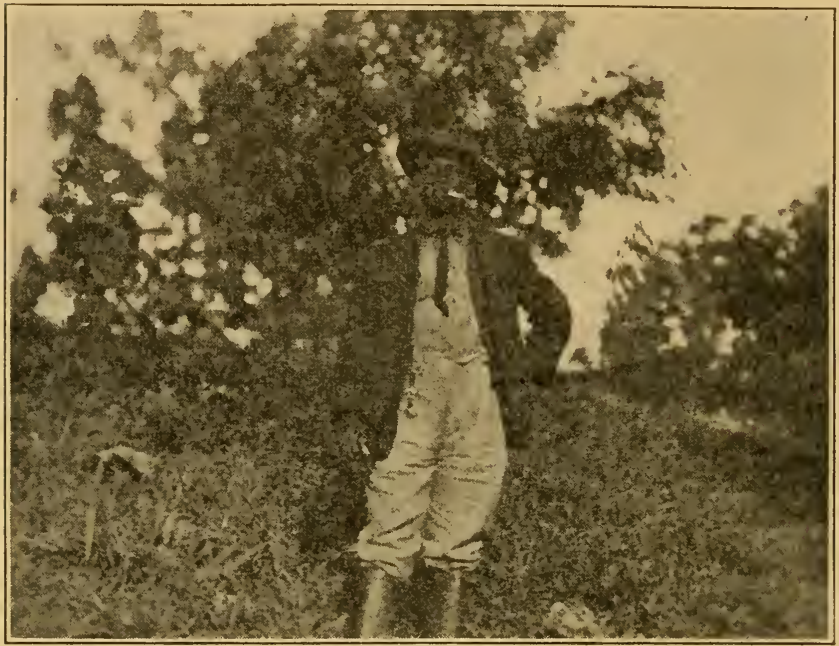

FIG. I2. John English

may be. With him were Santiago, the workman I had had the day before, who spoke English, Spanish, and a French patois, and Necto, who spoke only Spanish, but who was extremely polite and pleasant in that language. Before he took my pack he was always particular to shake my hand and ask after my health.

Santiago was clever in many ways, and I found him especially useful because he was a good camp-fire cook, and could be trusted to boil the 
drinking water. The clear water of the little brooks looks good enough to the ordinary negro to drink as it is. It is hard to make him realize that unboiled drinking water is one of the greatest dangers of the tropics to a white man, now that yellow fever has gone. The tiny, invisible animals with which it may swarm can cause the most difficult and wearing diseases.

Our own small dugout canoe, called a "cayuca" (Fig. I3) and chopped out by a Frijoles negro, was brought along the wharf and we loaded carefully, for it never balanced quite so well as less home-

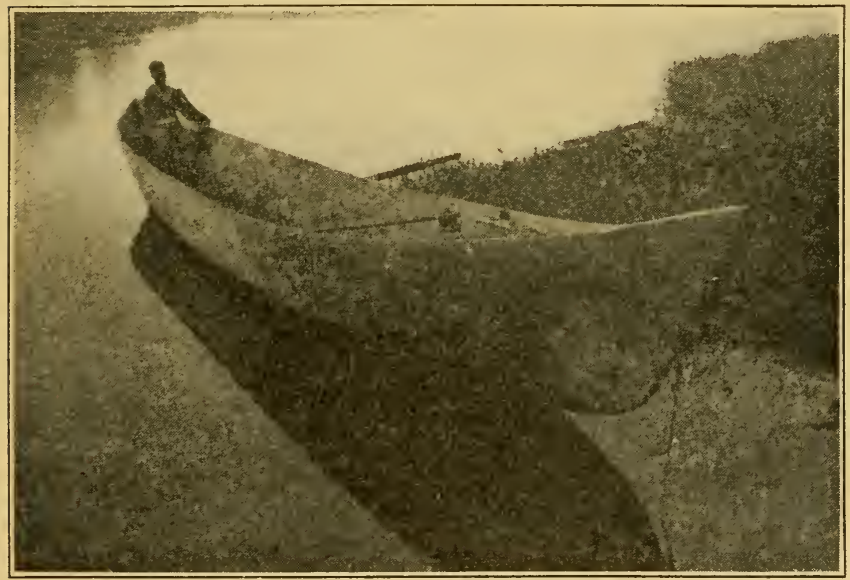

FIG. 13. The big cayuca

made boats do. Across the Frijoles inlet two negro girls swung out from the shore standing in another cayuca; but we sat down cautiously and were 
content to keep still while Necto at bow and Santiago at stern paddled us out between the stumps of dead trees.

All this was once a valley forest drowned when Gatun Lake rose. Some of the trees are very hard and solid and will stay in the water a long time unless they are dynamited to pieces. Through the dry season the water of the lake creeps a little lower every time the locks are emptied to let a ship out to sea. The dead snags of trees that were well under water in the rainy summer are close enough to the lowered surface to scrape the bottom of a cayuca whose boatsmen are not watching with sharp eyes.

The few houses of Frijoles village are built of lumber and screened. Farther out the roofs are of thatch, made of palm leaves, with walls of sheet iron or odd bits of board. Presently the walls disappear completely. The picture (Fig. I4) shows one of these, which Molino explained was a real palace, a casa grande. A whole negro family lived there, and they had room besides to take our Necto as a boarder.

I asked Santiago once how long it took to build such a house.

"Not too long," said Santiago. "Maybe three weeks if the moon is right."

Perhaps I should explain that he did not mean that the builder worked by moonlight, but that he thought the palm leaves would not dry into 
proper thatch if they were not cut at the right time of the moon.

Out past the point where the casa grande stood, we came into one of the wide bays of Gatun

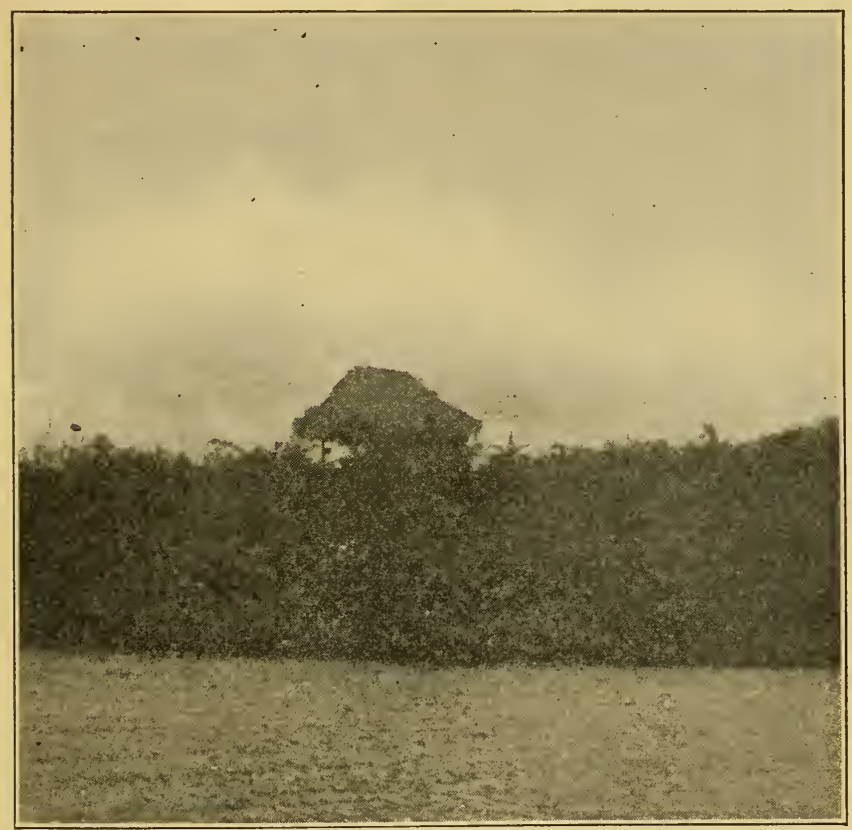

FIG. I4. The "casa grande" - a native hut

Lake, where we could sight across the Canal to Barro Colorado, whose nearest point was a mile away. But the wind was up and we knew that we might have to paddle over a three-mile route to reach a landing place, for the cayuca may capsize if the waves strike flat against its side or 
splash into it too heavily. Coming back from the island is easier, even though it is rougher. The wind increases through the day, but it is at our

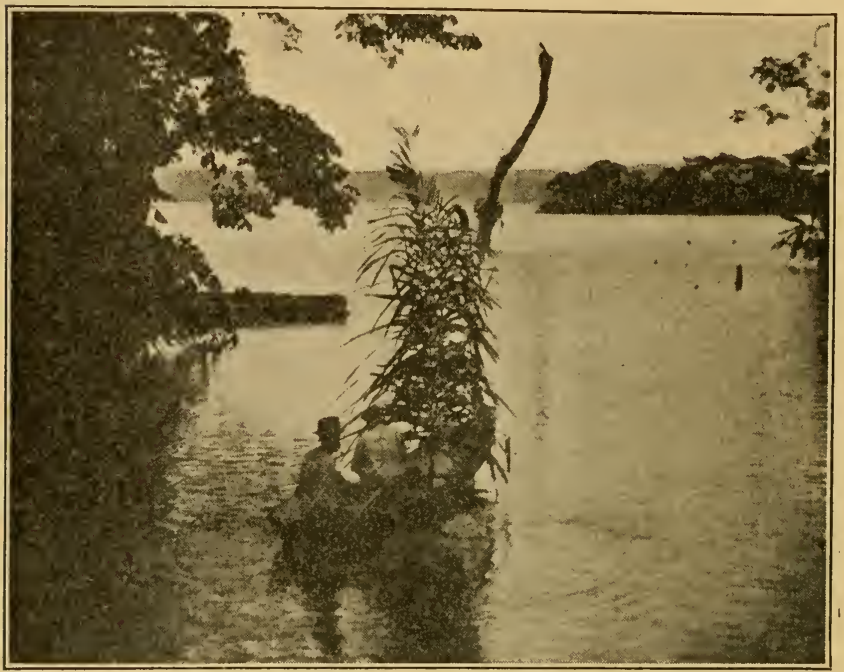

FIG. 15. The palm sail

backs, and the men make a sail of broad palm leaves tied together with tough jungle vine and run before the wind (Fig. I 5 ).

We always looked up and down the channel of the Canal, marked through the lake by red and black buoys, but ocean freighters seldom get so far from the locks this early in the morning, and we found it safe to cross. If we had heard the warning whistle of an approaching ship, we should have hurried out of its way, watching for 
the waves that spread on either side as it steams slowly down the channel.

At this distance the island looked like a mass of closely fitting green plants. Here and there were blocks of color like big bouquets. The red was of new leaves. Many smaller trees and spreading vines bloomed in pink and lavender. In February huge solitary trees blossomed in brilliant yellow. We looked at them from the water as long as we could, knowing that once we

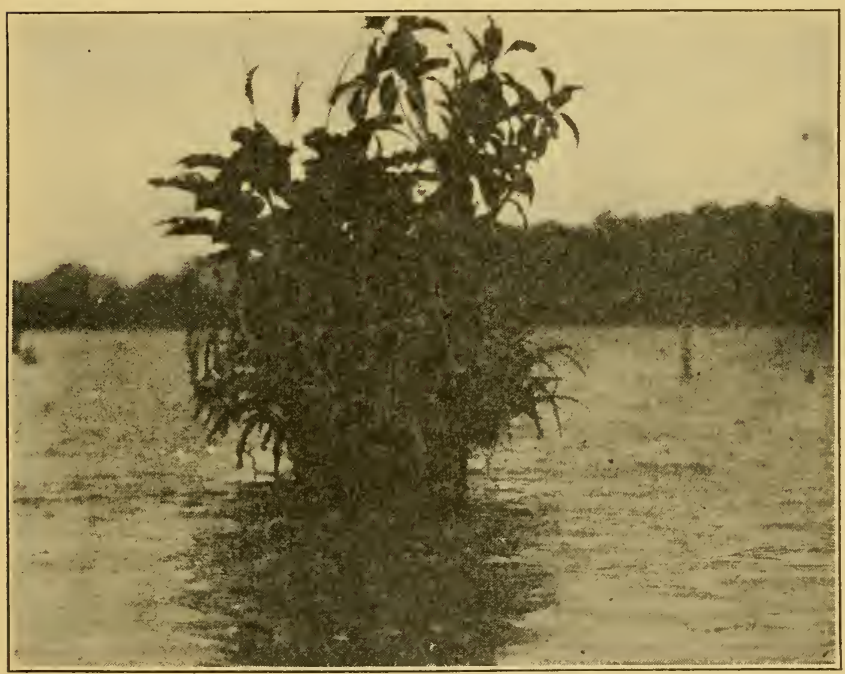

FIG. 16. The "flowerpot"

were under the forest roof the blossoms would be so high above our heads that we could not see them. 
Halfway across we were above the old village of Frijoles, for ten years now under the lake. Santiago liked to tell of living there when he was a boy. It was his joke that he was born under water. If he felt talkative he pointed out the old valley of the Chagres River below us and the place where the Frijolita River used to join it, "right there, Boss Doctor." But all that we could see was the dead tops of trees that used to grow on the banks of the rivers.

From the south came cayucas bound for Frijoles Landing, with bananas, oranges, handground corn for tamales, live chickens, or even pigs with their tied legs sticking stiffly into the air. The Canal is a highway, not only for ocean freighters and passenger ships, but for the negroes living in the small jungle clearings along the shore of the lake and the streams that empty into it.

On the far side of the Canal channel we entered Barro Colorado Inlet and made for the landing at the very end of it. The paddlers guided themselves by keeping a water-killed tree shaped like a harp in line with a tall tree on the shore (Fig. I 7). This channel was not cleared, and we had to be even more careful not to run the cayuca on any of the dead trees hidden under water. Most of the trees were gray and bare, but here and there an orchid clung to the side of one, and closer toward shore in the shade the lower stumps were topped with a heavy growth of ferns and flowers (Fig. I6). 


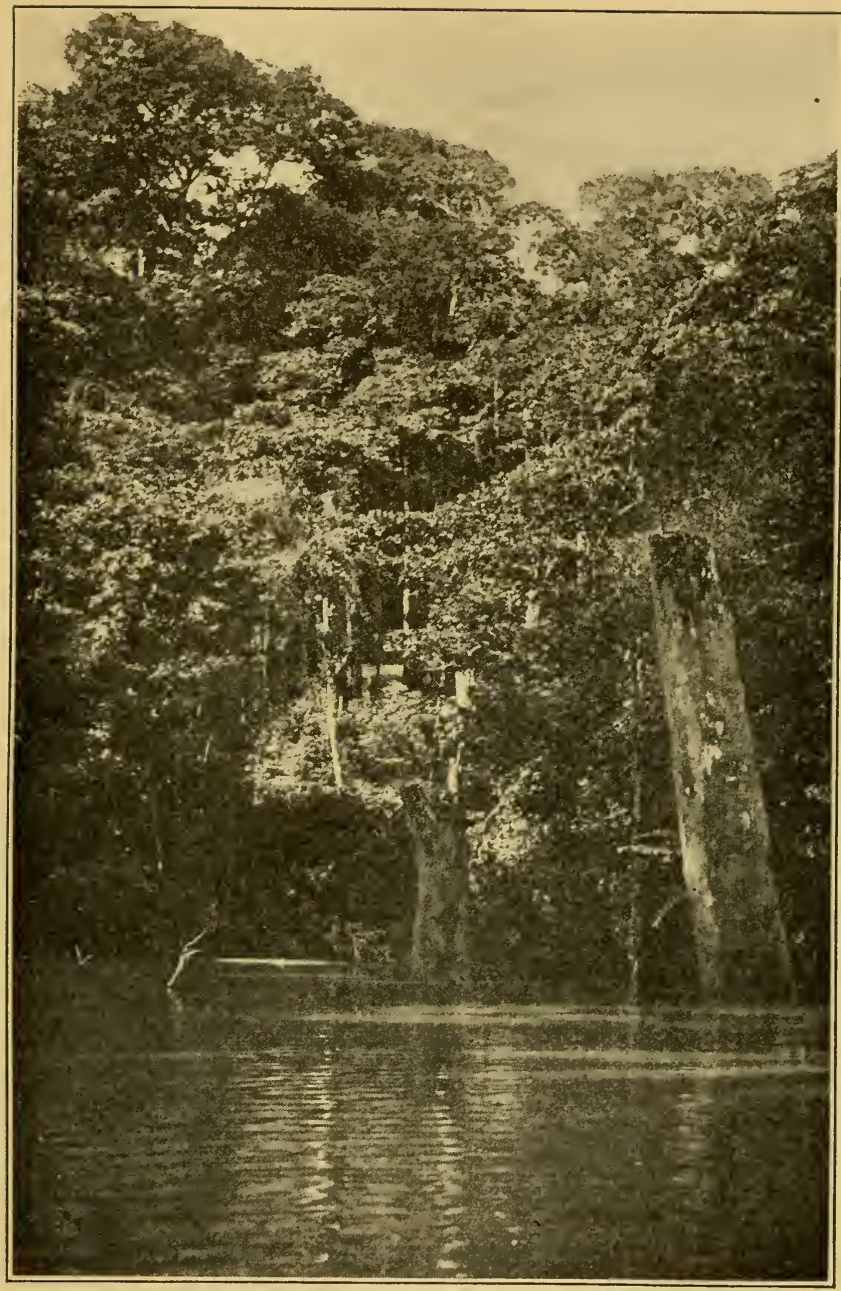

Photograph by Lutz

FIG. I7. The island from the inlet 


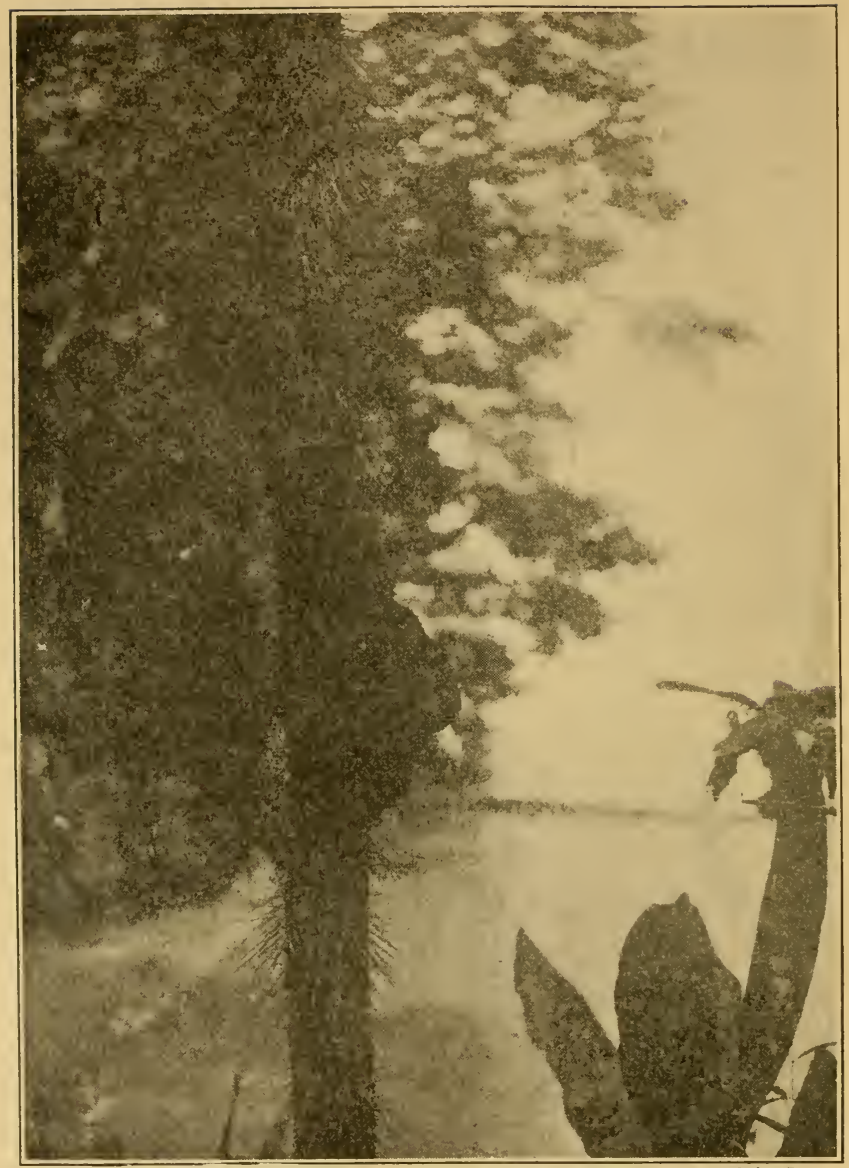

Photograph by Lutz

FIG. I8. Spanish bayonet palm with termite nest 
Plant growth on the shore runs thick and green even out into the water. It is so dense that a startled animal that has come down for a drink can plunge back through the brush with nothing but the noise of his passing to tell what it was.

Where a little stream joins the inlet a long dark log lazily moved off and disappeared in the shadowy water. This wàs a crocodile. It was on his account that we did not swim in the inlet.

Up the hillside in front of us the island brush had been cut away to make a red clay trail. We alighted at the foot of it and tied the cayuca to a Spanish-bayonet palm (Fig. 18). When I first came over to the island its thorns were as cruel as the weapon they were named after, but they were trimmed away without hurting the tree.

Fifty feet up the slippery hillside I liked to pause and turn to look back over Gatun Lake. Down the inlet was a lovely view (see frontispiece) which would have been hidden from this spot if it were not for the trail clearing. It was the only place on this part of the island where the green jungle roof did not shut away the lake.

An hour by train and an hour by boat it has taken to make the trip from American Ancon to our jungle island. 


\section{MY TREE}

I wanted very much to climb a big tree in the jungle. Most of the trees on Barro Colorado grow about ninety feet high and spread out into a thick green roof, but every so often there is a much larger tree that reaches above the smaller ones, twice as high. I wanted to climb up one of these tall trees above the jungle roof and see what was happening there, what plants and animals lived so high, and what they did.

Naturally there was no hundred-foot ladder lying around waiting for me on the island. If I got up a tree, I had to make some kind of ladder for myself. My first idea was to get some extra long railroad spikes to drive into a tree trunk for steps, but there were no railroad spikes to be had.

The manager of the Canal scrap department helped me out. He looked over his great piles of rusty machinery and found some bolts from the old machines that the French had used in digging at the Canal, and from these he had some stout spikes made for me. They were fourteen inches long, not quite an inch thick, and sharpened like a wedge at one end to make them easy to drive.

I took these over to the island one Wednesday morning, with Linder, a tall, lazy negro from the 
British West Indies, to help me. There was a funny little shack on the island, a good deal like the playhouse a boy might build for himself, and there I meant to stay of nights until my ladder was finished. We had rice and canned meat, fruit and crackers and tea enough to feed us for a few days.

It was not so easy to find the right tree as you might think. We climbed to the top of the slope and looked around. One tree was a good height and standing in a convenient place, but when I drove a spike into it the spike went in about an inch and shot out again. The wood was too hard and close-grained to make room for the spike.

I knew better than to try that kind of tree again. We walked farther and found a big thorny tree, called a sand-box tree. It stood well up on a ridge and towered over the jungle roof. The trunk was about five feet through at the ground. From the top of the tree hung large vines, called lianas, an inch to three inches thick. Most jungle trees are hung with these vines, which grow from the ground up and from the branches down. These lianas were as useful to me as ropes would have been.

The first thing we had to do was to shave the thorns off one side of the tree with our long knives, called "machetes." The native uses his machete for everything from a weapon to a hoe, 
and nothing could have been better for removing these woody thorns. It did not take long to clear them off as high as we could reach, although they had a milky juice that spattered unpleasantly into our faces as we worked.

We started driving the spikes early the next morning. Linder could drive the first one standing on the ground, and he easily sunk it half its length into the soft wood, leaving a good seveninch step. Then his troubles began. He did not want to climb, he did not want to work. He wanted a ladder to stand on, or an auger to bore holes for the spikes, or anything he could think of that we didn't have. The job "humbugged" him, he said, and I knew what he meant, even if I had never heard the word used that way before. Finally he decided that he could go on if he had a long pole for a sort of ladder.

While he was away looking for his pole, I drove the next spike two feet above the first. Then I tied myself to the second spike and stood on the lower one while I drove the third, two feet higher.

Linder's pole turned out to be convenient to use for one foot while the other was on a spike. We went on up the tree, driving spikes turn and turn about until we had reached the top of the pole. The work went slowly. My muscles were soft, and Linder was badly frightened when he was off the ground. It was still harder when we had to stand with both feet on one spike. We 


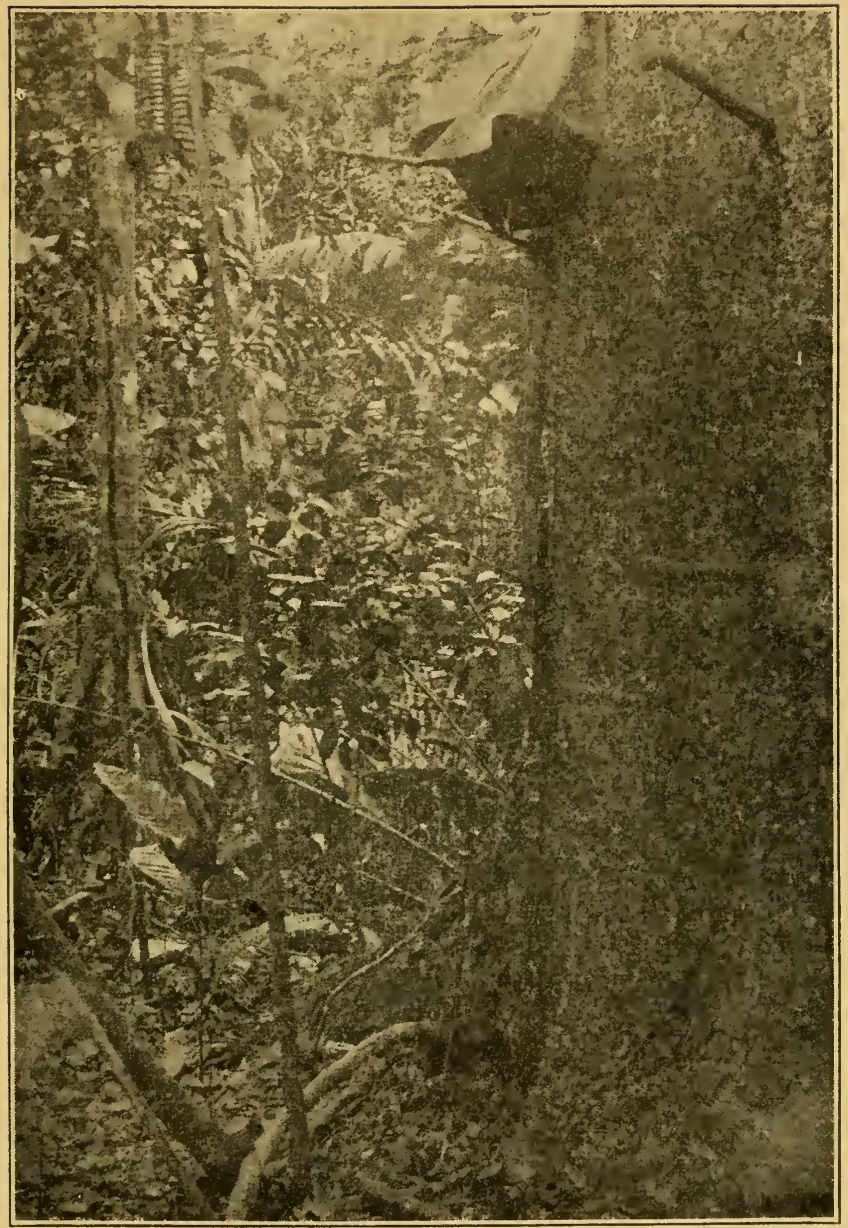

FIG. I9. The spike ladder 
tied ourselves to the tree again and used the hanging lianas to lean back against while we worked. Figure I9 shows the base of the spike ladder.

It was now Saturday morning, and Linder decided that he wanted to get away from the island, that the work was too hard, and that his shoulder hurt him very badly, and so we went back to Frijoles.

I never knew from one day to the next which of the Frijoles men would help me on the island. Sometimes those who had come with me most regularly would go off for a few days' work in the bananas, leaving a new man for me. Sometimes I found only one man waiting for me on the station platform and sometimes there were half a dozen to choose from. When I reached the island again late Monday morning, I found that Linder had brought over Santiago, and Santiago had already run the spike ladder twice as high as I had left it on Saturday.

Santiago had done much tree climbing in the days when he collected rubber. He climbed in bare feet, with a rope over his shoulder tied to the highest spike. When he reached the branches, he could stand on them or pass his rope around the body of the tree where it became smaller. By night he had driven spikes to the second big limb. This made a convenient saddle ninety feet above ground. 
The branches were fifteen inches thick and very strong. We could sit comfortably on them and look about us and down on the plants below. Not many white people get to see the jungle from above (Fig. 20).

I myself had seen it before only from a narrow trail, or working my way through the vines, ferns,

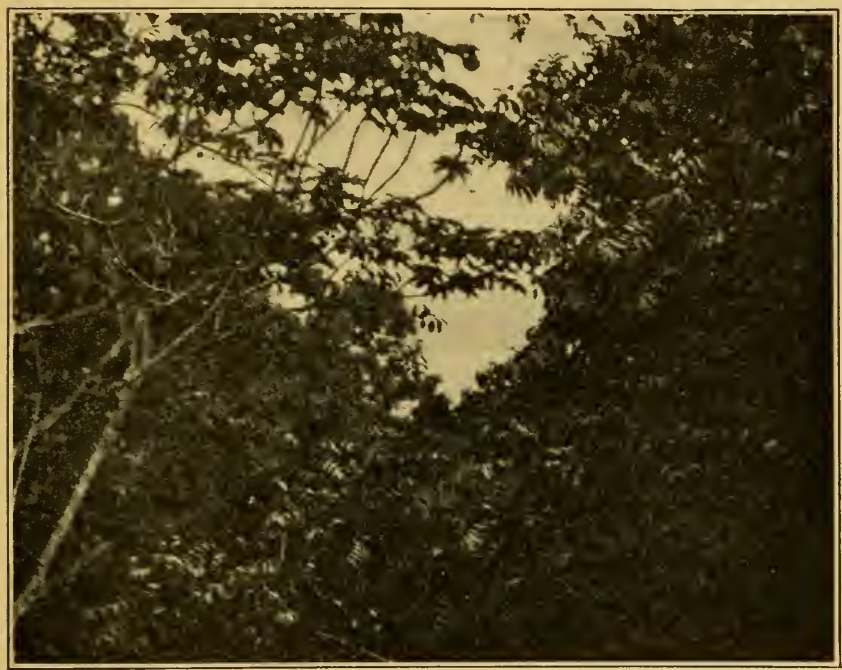

FIG. 20. Looking down on the jungle roof

and palms, where, if I was content to travel slowly, I seldom needed to use my machete to cut a path, though sometimes $\mathrm{I}$ was obliged to get down on my hands and knees to crawl under a tangle of bamboo vines or look for the next clear spot. A well-sharpened knife made a path 
faster, but I found only one place on the island where I had to use it all the time. This was in a patch of wild pineapple, higher than a man's head, where it took four or five strokes of the machete to cut one step through the stiff leaves.

My tree stood in a part of the jungle that was like most of the rest of the island. The plants did not grow so thickly as they did down at the shore, because the big trees shut off most of the sunlight. The red clay forest floor was loosely covered with dead leaves, and over it flecks of sunlight moved through the middle of the day, seldom staying in one spot more than a few minutes, but touching everything below at some time. All the lowgrowing bushes and ferns had a short time of sun for their broad green leaves, but not so much as to dry them out. A few flowers grew among the ferns in January. I saw a familiar milkweed whose flower makes a good insect trap, and the brilliant red blossom of the passion vine, which grows also in the southern United States. There were ferns like those we grow in our houses, as well as fern bushes six feet high and graceful fern vines (Fig. 2 $\mathrm{I}$ ).

The greatest difference between this jungle wood and the forest of a cooler country was the great number of palms. Some were only shrubs that could be cut as easily as a cornstalk. Some grew sixty feet tall, as straight as a rod, and were 
so hard that they turned the cutting blade of an axe. Near my spiked tree was a stilt palm (Fig. 30, page 69), so called from its manner of bracing

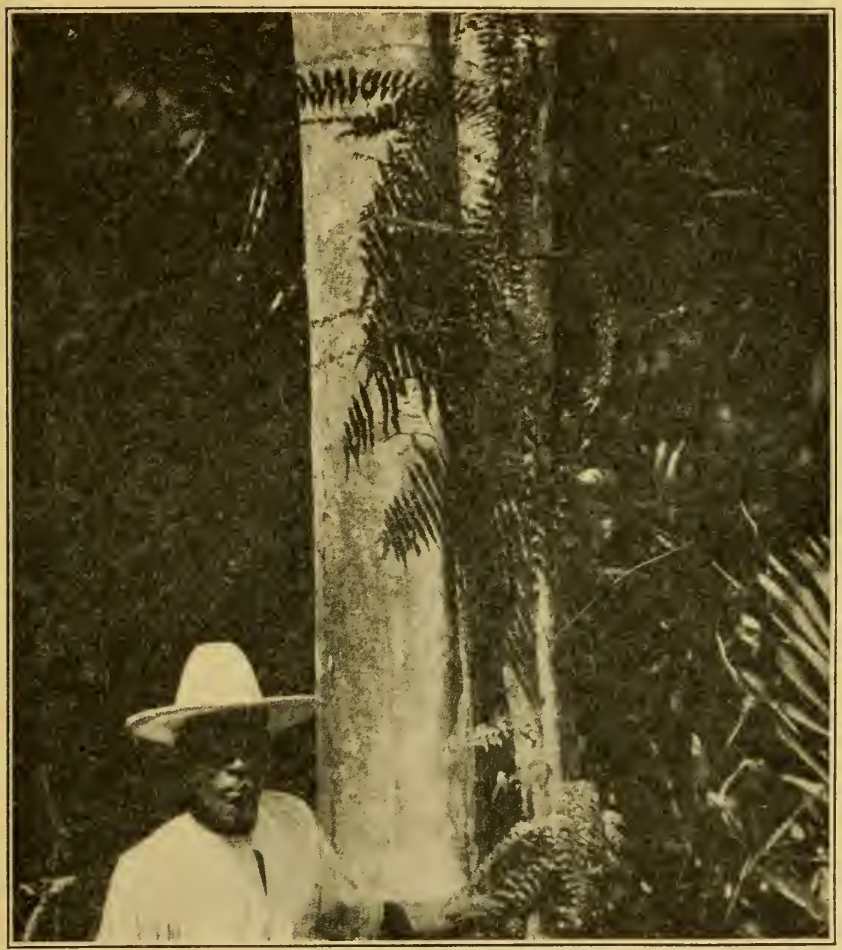

FIG. 21. A fern vine

its trunk with roots branching out five feet above the ground. You probably do not remember as well as I do the thorny Spanish-bayonet palm to which we tied our cayuca at the landing. 
When I had climbed only ten feet up the tree, I could look out over the tops of the lower shrubs. Another ten feet brought me above the smaller trees.

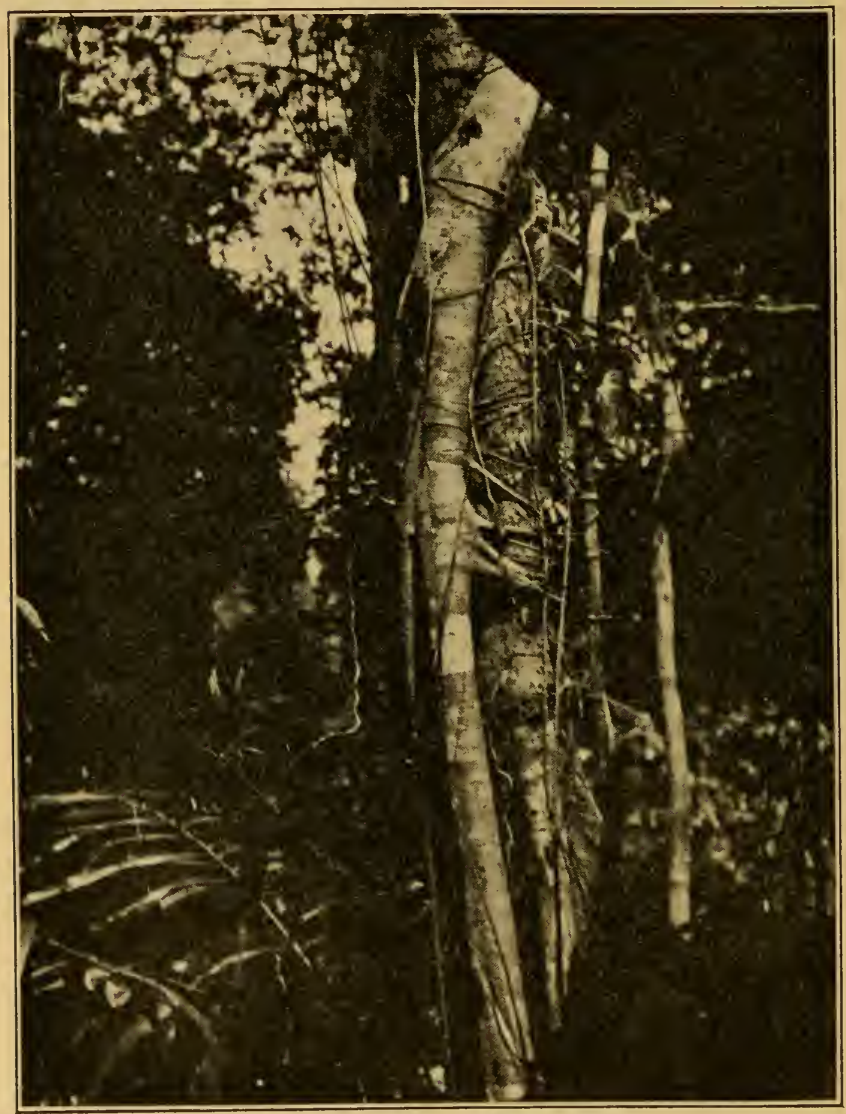

FIG. 22. A young strangler fig 
Now I began to notice especially the lianas. Some of these were the spongy roots of plants perched high on the big trees. Others are like our wild grapevine. They climb to the jungle roof and leaf out there, tying the branches together and helping to make the dense jungle shade.

One of the most interesting vines is the wild fig, which starts from a tiny seed dropped by some

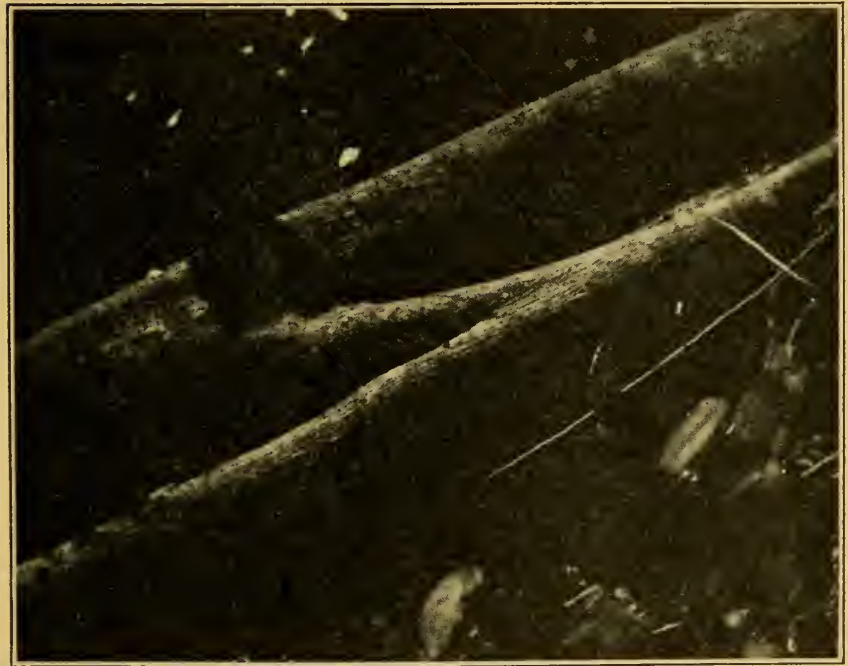

Fig. 23. Wild fig fallen after its inner support has rotted away

bird in the branches of a jùngle tree. This sprouts into a little plant which drops a root as fine as thread down to the ground. The rootlet thickens into a trunk that sends out from its 
sides dozens of other rootlets to hug the tree on which it grows until it is quite surrounded and smothered to death. Sometimes the wild fig stands like a real tree after the first one has rotted away inside it, leaving a hollow down the center. It is helped to stand erect by having its upper branches woven into the vine tangle of the forest roof, but if a heavy windstorm comes along it falls more easily than a real tree. Near my spiked tree I could see several wild figs at different ages. The pictures (Figs. 22, 23) show a young fig just beginning to take possession of a tree, and an older one which has lost its supporting tree and fallen.

Another liana that is most pleasing to find on a hot day is the water vine. One day, coming home from a long tramp across the island, our guide fairly jumped forward, as suddenly as if he had seen a snake. With his machete he attacked a large liana, looking like an immense twisted grapevine, and cut from it a piece nearly a yard long. The sloping ends were three inches across. Necto lifted one end over his mouth and water ran from it so fast that he could not swallow it all. He cut pieces for the rest of us, and we found the water cool and of a very good flavor.

Higher on the sand-box tree grew many plants that are never found except in such airy places as tree trunks and branches. Many of these are 
the plants whose roots make lianas. At a height of ninety feet I could lock down on one like a great rosette three feet across, whose glossy leaves

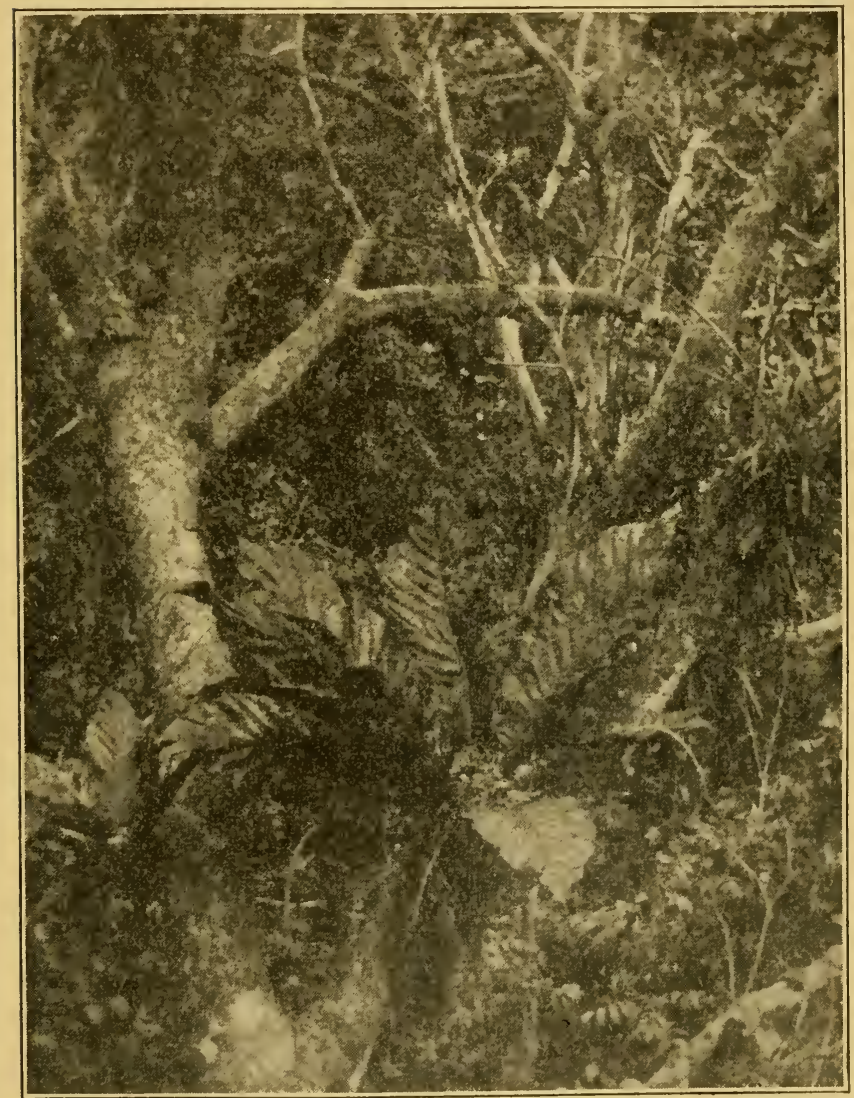

FIG. 24. Aeroid plants that grow as large rosettes near the jungle roof sending down spongy roots which absorb moisture from the air 
made a good photograph (Fig. 24). Perched among the branches are plants that look like the stiff tuft of leaves growing out of a pineapple. Their cupped leaves catch and hold water that helps them through the dry season. Flies, ants, and other insects drown in the water and are absorbed by the plant for food.

Perhaps the most beautiful of the tree plants are the orchids, which send up from their leaf rosettes a slender stalk, crowned with yellow or lavender flowers. If you cut out a large chip of the wood to which they are fastened, so that the plant itself is not disturbed, you can carry it away without harming it. Many verandas in Ancon have these lasting bouquets hung against their walls. In this moist climate they bloom on without attention.

At the top of my spike ladder I could again get a glimpse of Gatun Lake. The rest of the view was jungle roof, much as it appeared from the Canal. Here and there were other trees as high as mine, and in February some of them were gorgeous masses of yellow blossom. These were the guayacan (wy-a-con) trees, very hard-wooded. The wood is so hard that cart wheels are made of it simply by means of cutting off a round of the tree trunk, trimming it, and boring an axle hole through the center. Santiago told me about it. "Can't drive nail in it, Boss Doctor. Must use screw. Oh, hard, hard, hard!" 
Such hard wood is valuable, of course, but often it does not pay to try to get it out of the forest. From my tree I could see that the yellow-flowering trees did not grow close together. They were a quarter of a mile or farther apart. In the north we are used to woods that have nothing but oak or maple or pine trees for miles, but here in the tropics big trees of the same kind do not grow together.

The distances between trees make it impossible to use the machinery with which we haul the big trees of the northern woods. Usually only those trees are cut which stand on hillsides close to water, where the logs can be rolled downhill and floated away. Even this method has its difficulties. The thick undergrowth down to the waterside must be cut away before the log can be sent down the hill. When it reaches the water the $\log$ is often so heavy that it sinks like iron. Then some one must dive under it with ropes to lift it and tie it to a raft of lighter wood that will float and support it.

Mahogany trees grow in Panama, but the natives do not think its wood is nearly so good or beautiful as that from some other trees. They make rough furniture from it to sell to Americans, and sometimes a few logs are shipped to the United States.

Some of the less valuable wood is very light indeed. The "sentinel tree" (Fig. 62), one of the 
few that sheds all its leaves at once in the dry season, is nearly as light as cork. A log of it can be used as a canoe without hollowing out.

Down at the foot of my tree hardly a breath of air stirred all day long. For a whole week a thermometer hung there showed that the temperature did not rise or fall more than three degrees. Almost no water evaporated there.

This was true even when the wind was roaring past me at the top of my spike ladder. Up above the jungle roof the thermometer rose and fell twenty-five degrees in a day, and water evaporated three times as fast as it did below.

Above the jungle roof the wind and the sunlight were more free, since there were not so many branches to catch them and hold them back. On the ground I could not take snapshots even with a fast lens and special films, but up above I could take the pictures of the jungle roof shown here with an ordinary kodak.

Living at the foot of the tree was much like staying in a well-regulated greenhouse, with the same damp warmth day in and day out; but plants and animals up in the tree tops had a much more adventurous and changing life. Sometimes they might be warm and sometimes cold. The sun and wind would dry them out, or a sudden rain drench them. It is almost like living in another country for them. The light was over four hundred times brighter than on the ground. 
Some of them seem to thrive on changes, and are never found except high in the trees. Even these do not have to endure the changes in light and heat and moisture that the plants and animals of northern woods meet in the summer, which is our mildest season. 


\section{THE CLEVER FAMILY OF ANTS}

Ants are everywhere in the jungle and many are very big. They explore a new building quickly and use such parts as suit them quite as if it were their own property. Ants with long, powerful jaws like scythes run over the window screens and catch flies. Tiny ones climb on the table in search of crumbs and sugar. When I picked up an old tent cover or a coat thrown down and left in one corner of the shack for a few days, I was not at all surprised to find half-inch ants carrying away their white, grublike babies into dark crevices.

The life of any ant colony is wonderful to watch, whether it is in your own back yard or on Barro Colorado Island, but many of the most interesting and easily seen activities of the ants never happen outside the warm tropical countries. Ants, like men, are to be found all over the world, but warm climates suit the ants best, though men thrive better in cooler countries. One reason why ants are more active in warm countries is that their bodies are always the same temperature as the place in which they live. In the north they run around easily in the summer, but in the winter they must stay in their nests, cold as the ground itself and so stiff that they cannot move. 
In the tropics they can work in the warmth all the year round.

There have been ants on the earth very much longer than men have been here. Our best guess is that men have lived here half a million years, but we have good reason to think that ants have lived not less than twelve million years. The two families, men and ants, are the most intelligent of all the animals, and it would be conceited of us to say that men were always cleverer than ants, and not true, besides. We can learn more quickly than they can, but we cannot do nearly so many important things as the ants can without having to learn how to do them first. Through the long, long time ants have been on the earth they have come to live together in large colonies, where each one does his share of the work without having to be told what it is by any other ant.

Their accomplishments are more remarkable because most of them are blind. They use their sense of touch, especially in the long antennae or "feelers" at the front of their heads, to examine new things. Their sense of smell is very keen and helps them to keep to their usual trails outside their nests.

When I first walked through the jungle forest, I saw several paths about four inches across, hollowed down with much use until the center was an inch below the level of the forest floor. The leaves had all been removed from them, and the 
bare red clay showed signs of much traveling. Some of these paths were deserted, but along others marched files of leaf-cutting ants, called Attas. They came in a steady stream, about one to every six inches. Each carried in his jaws a rounded bit of leaf half an inch wide and threefourths of an inch long, held up and down like a sail. If the wind blows too strongly the ants are sometimes capsized.

Follow those that are going back for a fresh load and you reach a hillside where plants and bushes are being stripped of their leaves to a height of two feet. The Atta prefers green leaves, but I have seen in the same procession ants carrying bits of green leaves, of brown dead leaves, and of the pink blossoms which were falling from a large tree high above the jungle roof.

Attas are reddish brown and less than half an inch long. I wanted a photograph of them on the trail, and cut away an overhanging branch to let in all the sunlight I could get for a picture of such small creatures. The ants were bothered. They gathered at the edge of the sunlit space, and it was some little time before they ran across again. Neither do they seem to like to get wet. After an early morning rain the runways are littered with untidy leaf fragments which they have dropped to hurry home and which they clear away later when the rain has stopped. In very dry weather they stop work through noontime. 
It is easy enough to decide that they carry leaves home to eat, but it might be well to look in the nest and see. I found the entrance to one nest at the end of an ant trail that led half a mile from the hillside where the ants were cutting leaves. The entrance was a hole four inches across, level with the bare ground, at the top of a ridge. In spite of the fact that it was

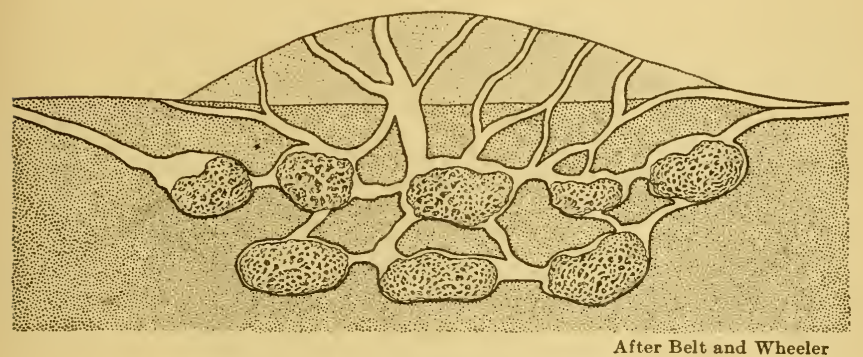

FIG. 25. The Attas' gardens

the dry season and the forest floor was covered with dead leaves, all the leaves had been cleared away for a rod or more around the opening of the nest.

The four-inch hole is the opening of a corridor leading to a large underground room, and from this room tunnels run to other rooms, in the kind of network shown in Figure 25. The ants have cleared the earth from these until each is about as large as your head. That is a large room for ants to make, but their work has only begun when the room is made. Ventilating shafts run up 
from each room to the fresh air. Often from the deeper rooms shafts run down into the ground, perhaps to carry off water in case of a heavy rain. The underground nest must be well drained.

In the nest the Atta returning with his leaf sail finds two other kinds of Attas. The larger one, much bigger than the leaf carrier, is a soldier with a well-helmeted head. His long jaws are strong enough to bring blood from one's finger. He never goes outside the nest unless it is attacked. It is his job to stay at home and protect it.

The other Atta is much smaller. Sometimes he may come out of the nest, and if you look carefully you may see him riding home again on a leaf sail carried by a larger worker.

- When the leaf carrier has brought his load safely down into one of the big rooms, he sets to work cutting it into smaller pieces, often helped by the workers that live in the nest. With their jaws and feet they make the leaf into a soft little ball, which is stacked away at one side with other leaf balls. The rooms are nearly full of these piles. Very few ants are so careless as to drop their leaves around unchewed.

Perhaps you think the ants are making hay to be eaten after it ripens. People used to think so, but they had not looked closely enough. These chewed-up masses of leaves are really garden beds on which the ants plant the kind of mushroom on which they live. 
So far as we know, these ants were the very first gardeners in the world, and very good gardeners they are. They are very particular in the care of their mushrooms. They plant the slips just the right distance apart to give each room to grow. They never let the parasol grow

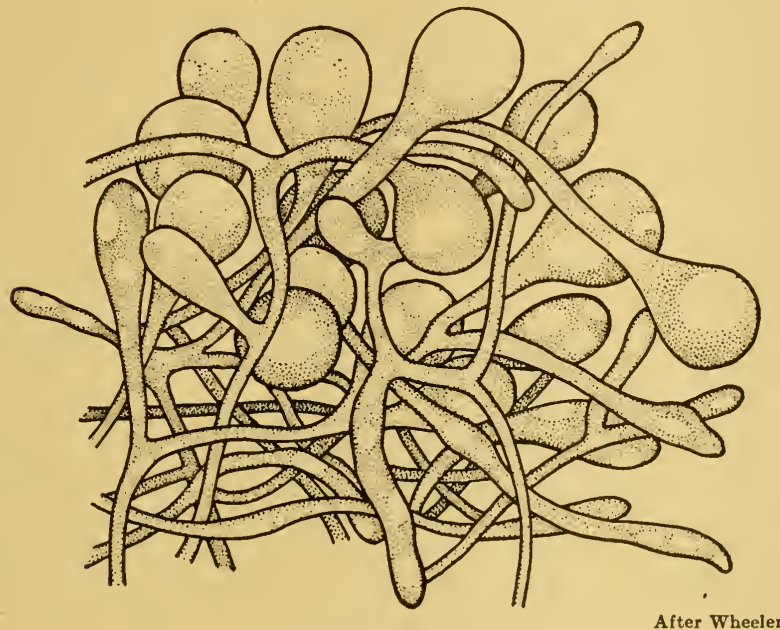

FIG. 26. Food mushrooms from the Atta gardens

out at the top of the mushroom stalk. The stalk is kept cut back nearly to the roots. When it is trimmed like this the mushroom forms little white balls. These little "cabbage-heads" are what the Attas want (Fig. 26). The workers eat them and feed them to their babies.

The special job of the smallest Atta workers is to keep the mushroom garden weeded. If 
other plants or different kinds of mushrooms start to grow in the warm, rich leaf mold, it is the job of the tiny Atta to kill them at once.

Leaves too wet or too dry would spoil the mushroom bed. This is probably the reason why Attas do not bring in leaves when it rains nor in the dry noontimes.

When a queen ant leaves the home nest to start a colony of her own, she carries with her, tucked away in her cheek, a small pill of the food plant which she tends as carefully in her new nest as she tends her eggs. She will even chew up the eggs to fertilize the plant's roots. As soon as the first young ants are large enough they take charge of the garden and begin carrying in leaves to make the garden beds.

All her life the queen ant continues to lay eggs. They hatch out into tiny, white wormlike grubs. These are usually placed near the top of the nursery, and there the smallest workers take care of them when they are not tending garden. They sort the grubs according to size and feed them differently. Watching very closely through a magnifying glass, you may see that when the tiniest grubs are hungry they pout out their lips. Then the first nurse passing by stops and feeds the hungry baby by brushing a bit of the mushroom food across its lips. Nurses are always passing about with food held in their jaws so that a grub does not have to wait very long. 
By the time the baby has grown large enough so that he can be watched without a magnifying glass, he is fed a whole ball of mushroom at one time, and he may have to beg from two or three nurses before he is satisfied. After he is fed, the nurses pay no more attention to him until he pouts again.

It may be from two to four months before the ant baby has changed into a full-grown ant with a dark, hard, leggy body in place of the soft white one he started out with. All this time the workers take care of him. They feed and clean him, carry off food he has not eaten, cocoons he has climbed out of, and all the odds and ends that might make the nest unpleasant to live in.

When he is grown he seems to know without being told that he must get to work helping with the food and the babies, or bringing in leaves, or defending the nest from enemies, according to whether he is a big or little worker or a soldier.

The Attas are one kind of ants, but there are as many kinds as there are nations and tribes of people. When I made the spike ladder up the sand-box tree I remembered that there were ants that bit and stung. One of my friends who climbed a tree in the South American forest met a colony of stinging ants seventy feet up the tree and was glad to get down from his ladder as fast as he could, and not attempt to climb back again. 
I myself met the big black ants Figure 27 shows, called by the natives "Congos," living at the root of a tree in a well-cleared forest trail. If some

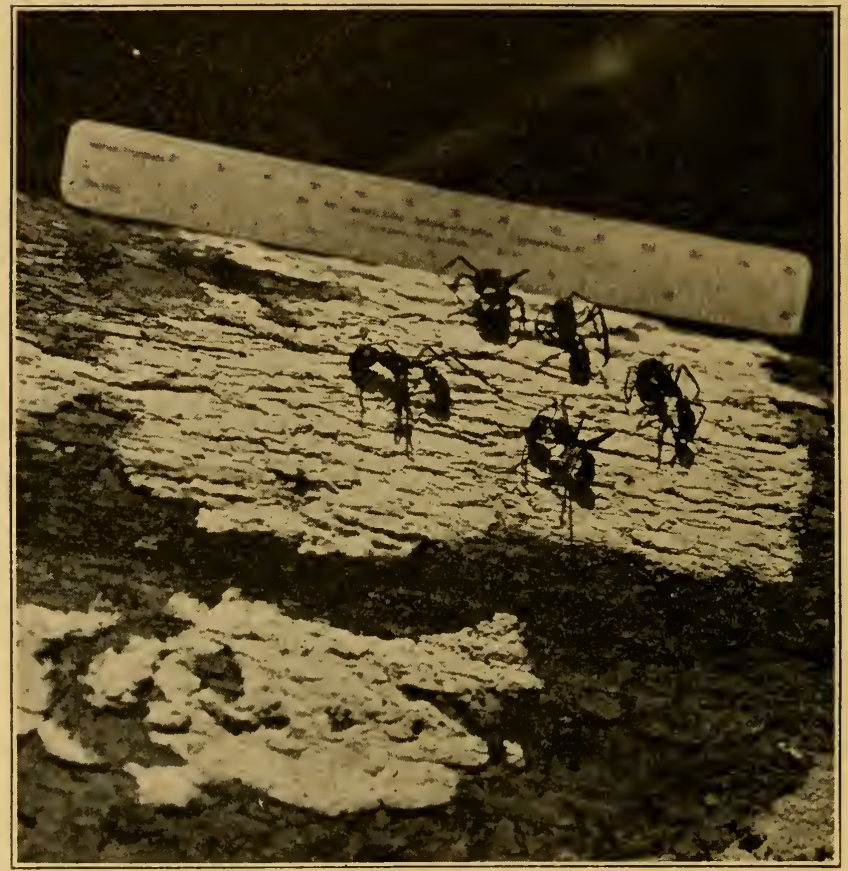

FIG. 27. Big "Congo' ants

one knocked on the tree, the ants rushed up from the ground in fighting humor, and the sting of one of these inch-long warriors was as lasting as a hornet's. They came into my shack searching for food. At night they could be seen hunting up and down their tree trunk, always on the same 
side of the tree, seeming, like most ants, to follow a trail they could smell. I knew that a nest of these in my tree could make a great deal of trouble.

Up about fifty feet we met a colony of small ants coming and going, but they did nothing more

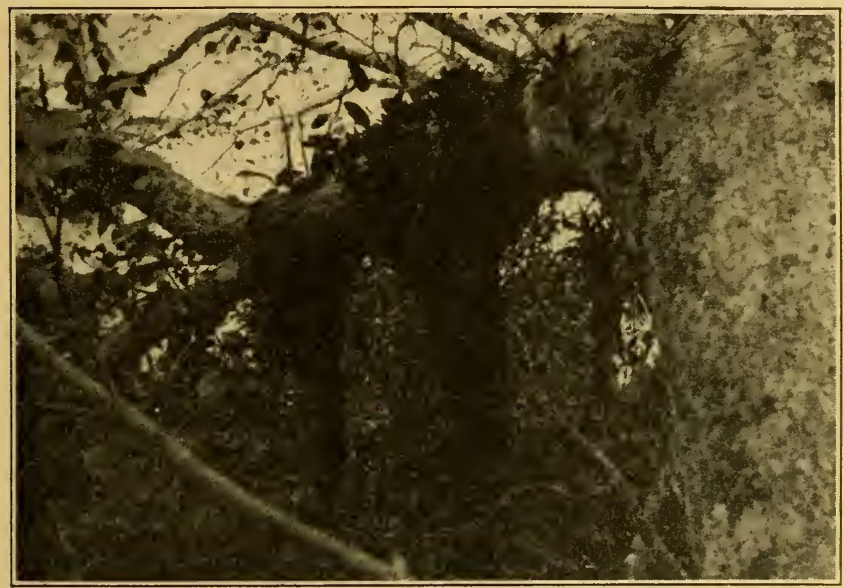

FIG. 28. Azteca ant nest. Plants grow on the nests and tree trunks

than tickle and annoy us. At eighty feet we found their nest, hung from a branch like a huge, blunt gray-paper icicle (Fig. 28). These ants are paper makers and we have given them the name Azteca because they live in the land of the old Aztec Indians.

They make their paper out of the tiniest.bits of wood or plants, chewed well and glued together 
by sticky juices from their mouths. The paper of the nest in my tree was quite thin, and tough enough to bend without breaking. In a country where there was less rain the paper would be more brittle.

We never saw these ants near the ground, but when we climbed the tree we always found them traveling about high up in sunny, wind-swept spots very different from the ground trails of the Attas. They followed the same paths, which looked no different to me from any other part of the bark of the tree, and which they must have followed by smell. Each time we climbed the tree we had to kill several of them so that they would not crawl over us while we worked astride their pathway.

Down in the Brazilian forest of South America lives a relative of some Barro Colorado ants that makes its nest in a still odder way. The nest is made of leaves fastened together with silk. The grown ants cannot spin silk. The baby ants can spin silk, but they cannot weave it. This is what happens:

The big ants take the grubs in their forelegs and hold them against the leaf they want to use, until the silk thread dries on the leaf edge. When the end of the thread is glued tightly the little grub is carried across to another leaf edge, spinning the thread as it goes, while other ants hold the leaf in place (Fig. 29). Back and forth, 
crisscross, the baby ant is carried until the leaves are firmly woven together and the little living spinning machine is allowed to rest.

Often I found on Barro Colorado a black ant about half an inch long with great sickle-like
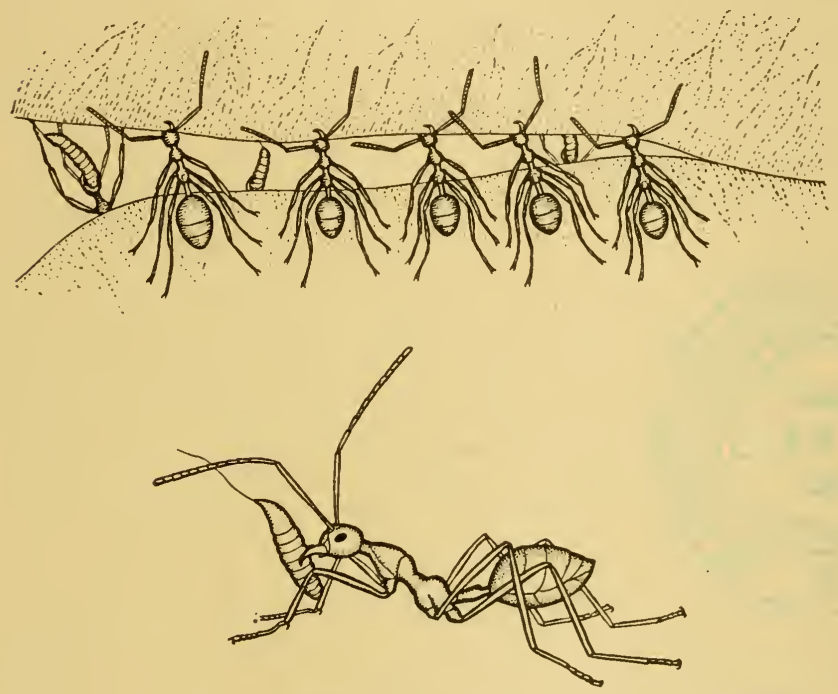

After Wheeler

Fig. 29. Ant weavers

jaws. These jaws were usually carried wide apart, but they could be brought together with a snap that I could hear several feet away. These were the army ants, the Ecitons, and one of my reasons for going into the jungle was the hope that I might find their nest, the most wonderful of all the ant nests. 
The army ants are not plant eaters, like the Attas. They are meat eaters, like the big fourlegged woods animals. They eat insects, the baby ants of other ant families, and any small animal that is unfortunate enough to get in their way. Since they are so nearly blind they hunt together, a great many of them in an army, each following the other by the sense of smell, and in these great numbers they can overpower the largest animal in their path.

It does not take them long to clean up all the small creatures in one place, and then they must move on to find food in new country. Probably they cannot stay more than four or five days in one place. Then they move off again in a long line, thousands and millions of them. The workers carry the little white baby grubs in their jaws. The soldiers move up and down the line, directing it.

They do not have time to dig the big underground rooms that the Attas live in, nor to make paper for nests like the Aztecas, but they do make nests even when they settle down for only half a week. It would be no use to ask any one to guess what they use for building their portable houses, and yet it is the easiest material they could find and can be put up quickest. They build with live ants!

Each ant fits into place into the walls as if he were a brick. With his long legs he holds 
on to the ants about him. When the nest is finished it may measure as much as a yard in every direction. It is usually built under a log or something solid that serves as a roof and reaches down to the ground. From a doorway tunnels lead back into the nest, and there are rooms at the end of these for the baby ants. Everything-floors, cieiling, walls, and all-is built of live ants holding firmly to one another. Down the living halls the hunters run in and out, carrying the food they have found to the workers and baby ants inside.

No one knows how these ants make their nests so cleverly and well without any one to superintend the whole task. It is one of the things that ants have been doing so long that they do not need to be taught how to do it, any more than a baby needs to be taught how to cry.

I never found any great number of the army ants on the island. Perhaps when the waters of the lake rose round the hill, the big armies were off hunting in some other place. Perhaps they prefer a climate that is still more rainy. I was sorry not to see their wonderful nests, but the little animals of Barro Colorado are safer than they would be if they were penned up on the island with armies of hungry Ecitons that had to stay there, too. 


\section{TERMITES, THE DESTROYERS}

Whether I tramped along a partly cleared jungle trail or scrambled up a rocky, nearly dry watercourse, I was continually catching sight of rough blackish-brown balls fastened to the trees. Some were only four or five feet above ground. Others were eighty feet high (Fig.62). Some were the size of footballs; some were three feet through. In one mile I counted fifteen. They were the most noticeable animal buildings in the jungle.

One of these is seen in the picture of the stilt palm near my spiked tree mentioned earlier, and shown here (Fig. 30). Molino had struck off the stony outer shell with his machete blade to show me what was inside. The shell fell away and showed hundreds of tiny runways within, with small, white antlike animals hurrying about. These were termites, often called "white ants," but not ants at all. They are cousins to the cockroaches, and are no more closely related to ants than kangaroos are to men.

Like the ants, the termites are a very old family, and in the many years they have been on earth they have built up a way of living together that is very like that of the ants. Some of them live in the cool countries. I have found them in Massachusetts and the Indiana sand 


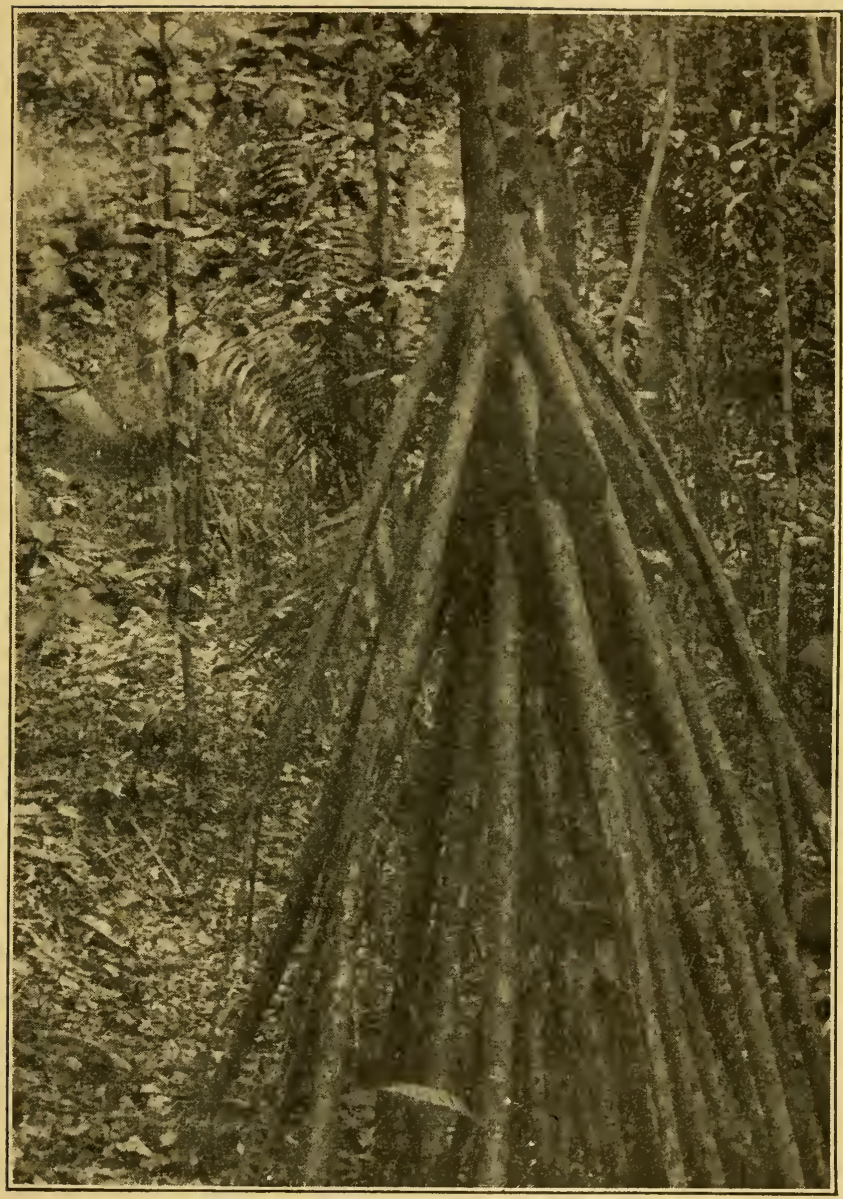

FIG. 30. A stilt palm with termite nest 
dunes, but they are much commoner and more important in the warm countries.

The termite tree nests are made of paper mixed with clay and cemented in place with juice from their mouths while it is still moist. Like the tree ants, they make the paper by chewing up

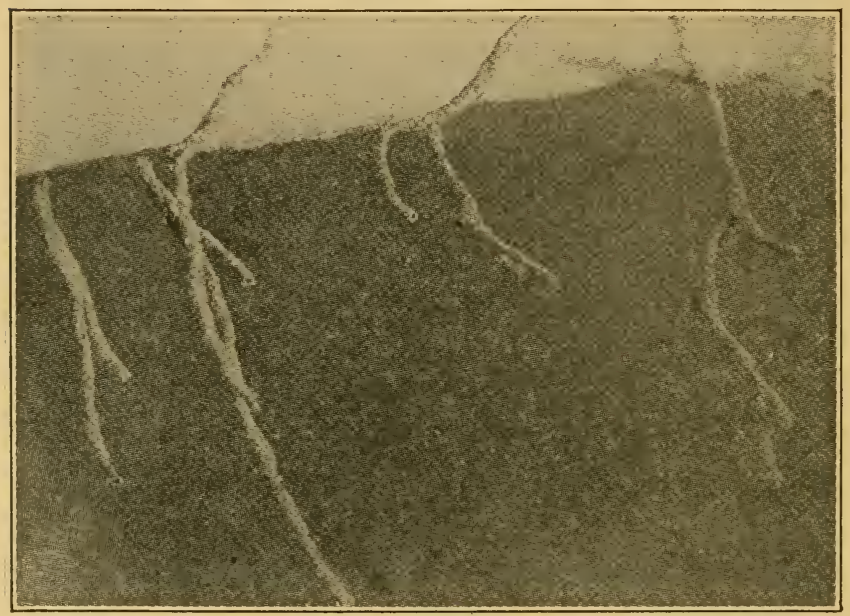

Courtesy of U. S. Department of Agriculture

FIG. 3I. Termite runways built into space

wood. Some of the nests are so hard and flinty that they dull the edge of a machete. They are very much more solid than the nests of the papermaking ants. No opening can be seen. The termites come and go through covered tunnels. Wherever the termites go they build these tiny runways to travel through (Fig. 3I). If they go down tree trunks or over the ground, they make 
arched tunnels. If there is nothing solid on which their pathway can rest, they build a round tube. The same clay-and-paper mixture is used here as in the nest.

The workers venture out from the open end of the runway less than half an inch, carrying their tiny speck of material to extend the tunnel. On the roadway marked out by the first workers the others pat in place their little balls before the mixture hardens. A little more than an inch of tunnel can be made in an hour.

These covered roads, branching frequently, lead off from the big nests down the trunks of the trees. One tree of which I took a picture had a network of tunnels over its bark like the veins under the thin skin of a race horse (Fig. 32). Some of the runways end at the ground where the termites get water and dig clay mines and construct underground nests. Others are built as far as three hundred feet from the main nest and end in smaller tree nests. Often these smaller nests are on dead timber. Where the jungle has been cleared away and people are trying to farm, their fence posts are often capped with the smaller nests.

The termites are very enterprising in their road building. I found they had invaded the bed of a stream that three months before in the wet season had been a raging torrent, though now it was only a little brook. Their arched runway led from a moist and decaying palm, across a 6 


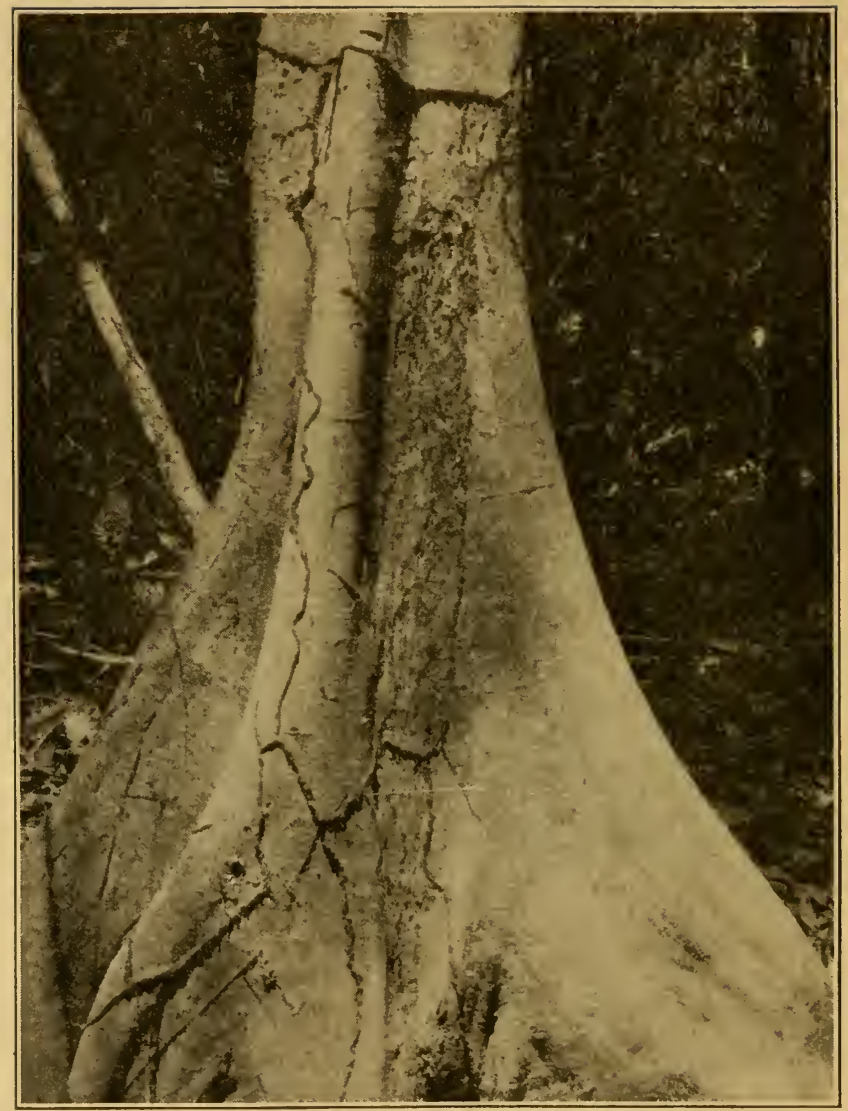

FIG. 32. Termite runways on tree trunk 
broad flat stone to sand and gravel on the other side.

When roads or nests are broken open, you may see many small termites with brown heads. From the middle of their foreheads sticks out a single hollow horn that makes a most excellent squirt gun (Fig. 33). I took some termites in my hand, and soon the whole hand was covered with a clear, sticky liquid like cedar oil, which I found hard to wash off. These are the termite soldiers, whose duty it is to protect the colony, and their sticky weapons are very useful against most of their enemies. Other termite soldiers are armed like the ant soldiers with large biting jaws.

The termite workers are a little larger than the soldiers. They do not have squirt guns, and their jaws, though very strong, are not overlarge. It is their business to build nests and runways and bring in food.

Deep in the center of the nest are rooms called "queen chambers," and in each of them live from one to ten queens. The queens are much larger than the tiny workers and soldiers. Their bodies are often more than an inch long, six times the length of a worker. The queens' chief occupation is to lay the eggs that will hatch out into new termites to carry on the business of the nest.

"Kings" are usually found in the queens' chambers, too. They are larger than the workers, 


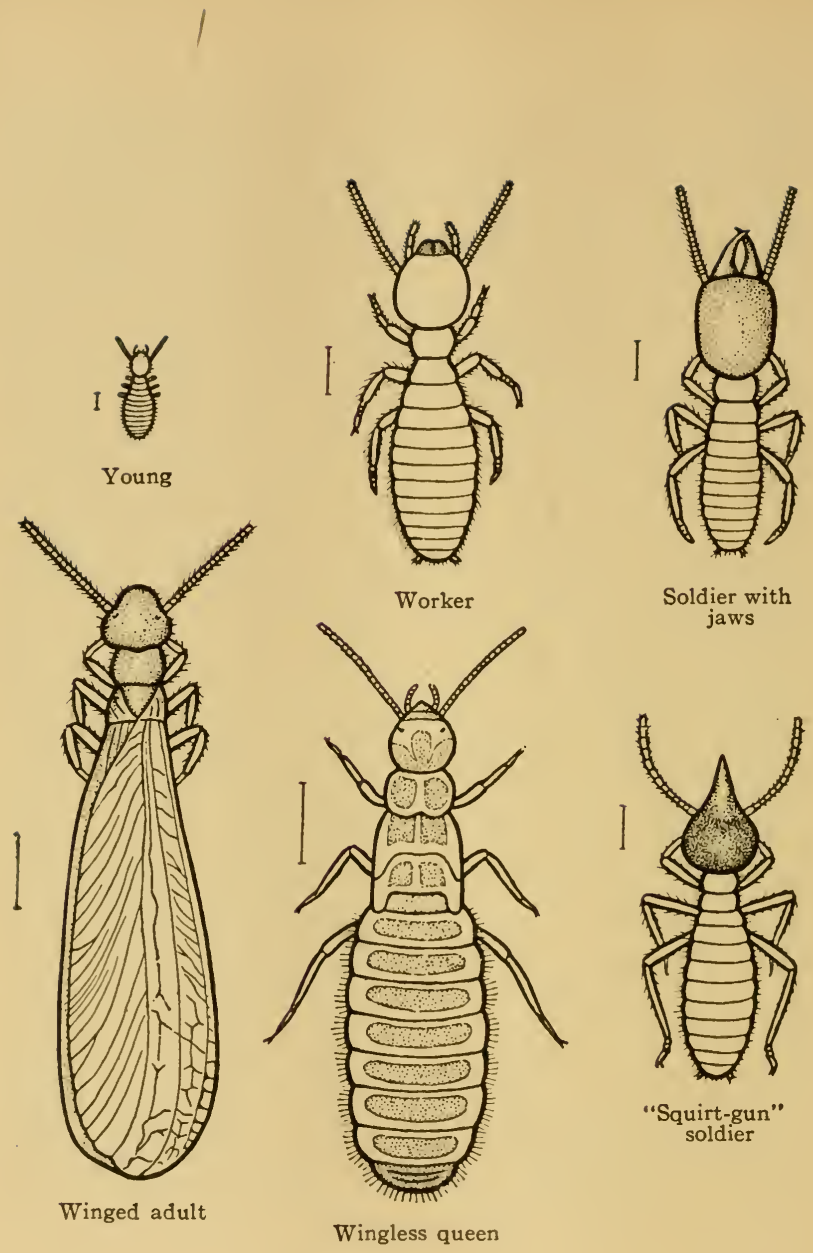

No. 6 original. Rest after Grassi FIG. 33. Termites 
but smaller than the queens. Sometimes there are three different kinds of kings and queens living in the same nest.

Altogether there may be five kinds of termites in the same colony: the soldiers to protect the nest, the workers to build, to hunt food, and to care for the young, and the kings and queens to produce eggs.

Most of the year there are only a few kings and queens in each colony, but in the spring, about the time the rains begin again after the dry season, a great many princes and princesses are hatched out. None of the other termites in their family has any wings, but each of these has two pairs.

You will remember that the hard shell of the termite nest completely covers it. There is no opening for termites to get out or anything else to get in. But when the rains come and all the princes and princesses are hatched out, the workers make holes in the nest walls while the soldiers mount guard to kill ants or other interfering enemies.

When all is ready, usually at the end of a warm rain, the royal children climb out and fly away into a world that they have never known before. They are heavy-bodied like their parents, and fly slowly. Birds eat a great many of them, but there are still enough left to trouble the natives who do not have screened porches. Swarms of 
termites fly into their faces and hair and fall into their food. If the Panamanians have been spending the dry season in the country, they know it

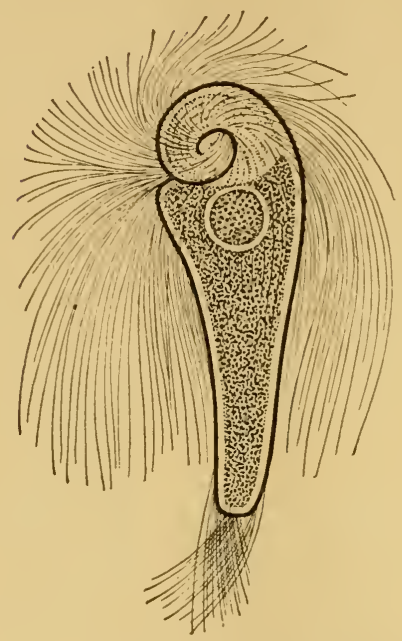

FIG. 34. The termites' wood-digesters

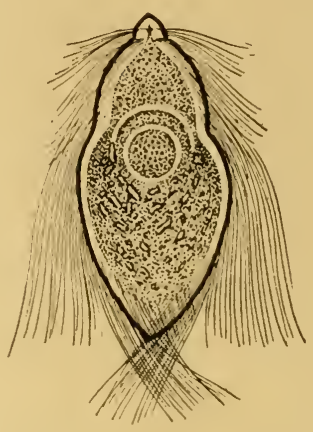

After Leidy

is time to move to town where they will not be bothered so much.

After a flight of a few hours the termites bite off their own wings and are then ready to settle down. Two of them mate, build a nest, and start a new colony with themselves as king and queen.

The building habits of termites are interesting, but what they eat is much more important to us. These tiny animals live on wood, which the 
workers gnaw away in tiny bits with their strong jaws. Wood is not easy to digest, even for a termite, and these workers make use of a strange way to get it done. Inside their bodies, in their intestines, are thousands of very small one-celled animals called Protozoa, which look, as Figure 34 shows, more like a decorative design than a wood factory, but they are able to digest the wood swallowed by the workers so that the termites can use it for food. Some of the soldiers and the royal family cannot even chew wood. For these the workers produce a liquid like milk which

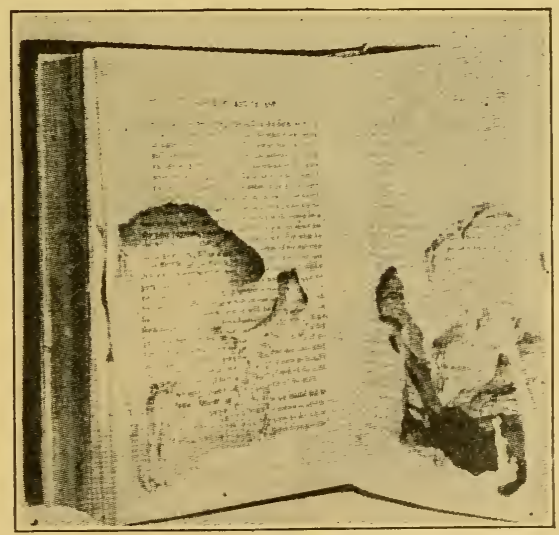

Courtesy of U. S. Department of Agricurture

Fig. 35. A book damaged by termites on shelf in room. The damage was done in onerweek's time

gathers in drops around their mouths. The others feed on this milk, and the workers may feed each other or even swallow their own liquid. 
Sometimes the termites eat into living trees and kill them. Coconut palms and even sugar cane are damaged by them, but more often they feed on dead timber. This is the reason why they are so frequently found in fence posts and buildings. They are eating up the wood, leaving nothing but a shell. Nothing escapes their attack.

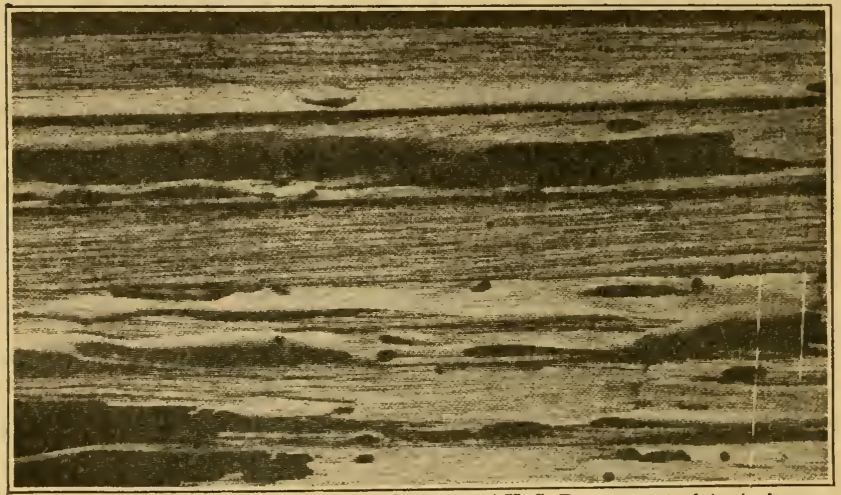

Courtesy of U. S. Department of Agriculture

FIG. 36. Hard beech wood from drawer of a desk damaged by termites in a building in Ancon

They eat telegraph poles, houses, railroad ties, bridges, furniture, ships, books (Fig. 35 ).

They destroy wood and timber worth millions of dollars every year (Fig. 36). Only recently the government of the United States spent ten thousand dollars repairing the damage that termites had done to one building, the Hotel Tivoli, in Ancon, which is owned and managed by the government. 
Their most remarkable and unexpected feat was to bore through the lead sheathing of telephone and telegraph cables laid underground and even through the sheathing of cables carrying a strong electric current through the locks of the Canal. In one place alone fifty feet of cable had to be replaced.

One company has laid a cable across the Isthmus about a foot underground. They find that where the line runs close to timber the termites are likely to make their way over to it. The little destroyers eat through the outer waterproof coverings of rubber and lead, half a dozen holes to the foot. They eat out the sheathing of the bundle of wires that make up the cable, and if they find "dead wires" without an electric current, they follow these along, stripping the separate wires of their wrapping as they go. This performance seems to be pure mischief, since, so far as we know, they cannot digest metal or rubber. Possibly they use bits of it for nest or road building, for it is not much harder than some of the clay that they mine. It seems to me more likely that they have the habit of chewing anything they find and, like some children, do not use judgment in what they eat so long as it is conveniently in reach.

Soft wood-for example, pine brought in from the north for building - is quickly eaten and ruined, unless it is soaked first in creosote poison, 
and even then it is not altogether safe. The termites prefer other wood to creosoted wood, or to the very hard and heavy native woods, like the timber of the guayacan tree, but if the near-by timber becomes scarce they will work even on these. Some of the wooden forms into which the cement was poured to make the walls of the great Canal locks were of both hard and creosoted woods, but they have been attacked by termites where they were left in place around the cement. Probably this was because the country around the locks is well cleared of wood and even small bushes, and the termites there were hard driven to find food.

When we were building a wooden laboratory on Barro Colorado we placed the timbers on cement foundations so that no wood could come in contact with the ground and attract a venturing termite scout. The laboratory was set on the top of a high hill sloping down to Gatun Lake. The red clay hillside was slippery enough in dry weather, but after a rain it was impossible to reach the top without hobnails in one's shoes and a firm grasp on the strong lianas that the men had tied to trees along the path. A long flight of steps had to be built to the laboratory from the boat landing by the Spanish-bayonet palm. These rested on the ground. They were made out of seasoned native timber, so hard that nails could not be driven in it unless nail holes were 
drilled first. Where softer wood had to be used because it was less expensive and easier to work with, it was treated with creosote poison. It is my guess that even with these precautions the busy termites will not let the stairs stand many years without needing repairs.

As the Americans cut down and burn the tropical jungle and build wooden houses and fences and railway bridges, they are taking away one food of the termites, but giving them another which suits them just as well, unless it is better protected from them than it has been up to this time.

New ways to discourage the termites are tried every year. I saw a little experiment made last winter that tickled my imagination. In the jungle live three different kinds and sizes of animals called anteaters, for the very good reason that ants are their chief food. They break open ant nests and run their slender, sticky, wormlike tongues down the tunnels, drawing them back covered with ants. One of these anteaters is just as fond of termites. He is shown in Figure 37 making a good meal from a termite nest. On his strong front legs are long claws that break through the flinty shell of the nest. I wondered whether the Canal Zone might not start raising herds of these convenient anteaters to keep the termites down!

Not all of the termites' work is harmful. Their mining stirs and softens the ground just as the 


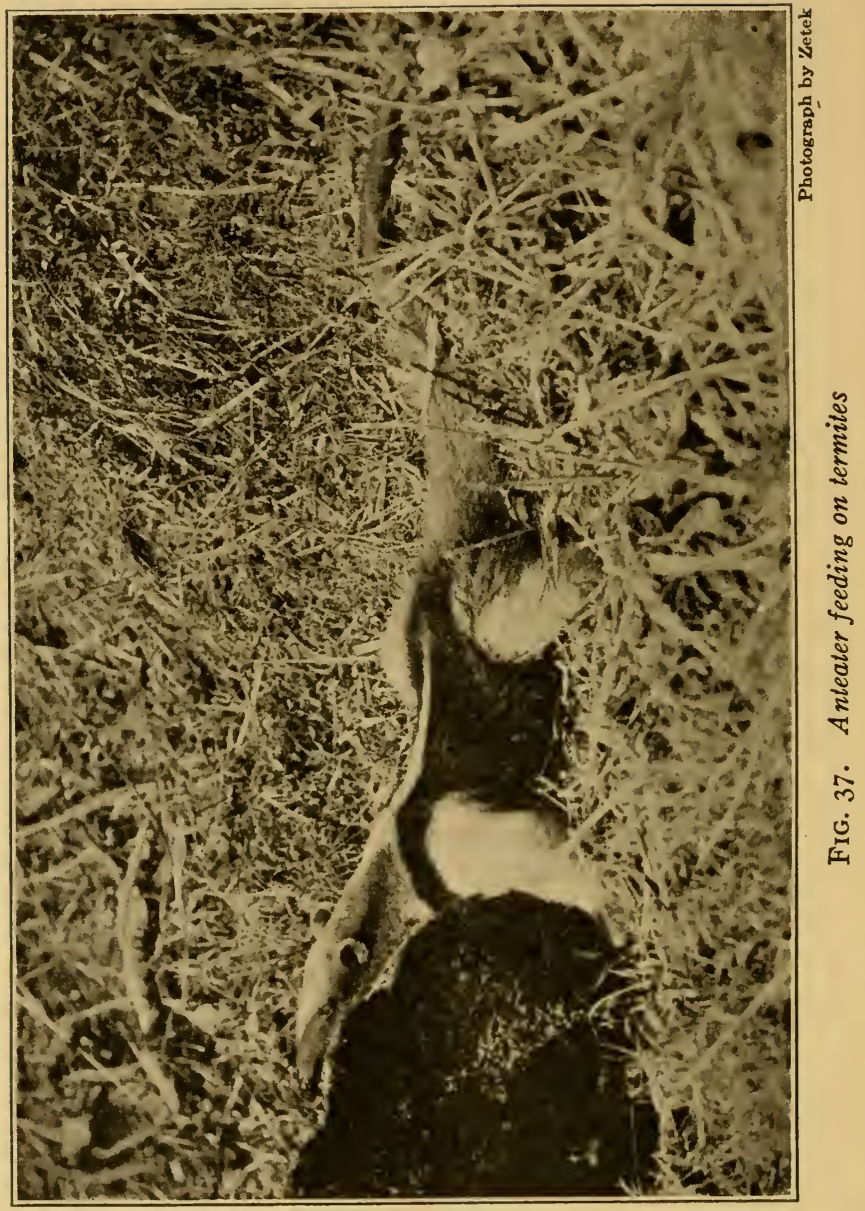


burrowing of the earthworms does; and their very habit of wood eating, which is so destructive in the wrong place, is often useful in the jungle, where it turns dead wood quickly back to fertile soil which supplies food for other plants.

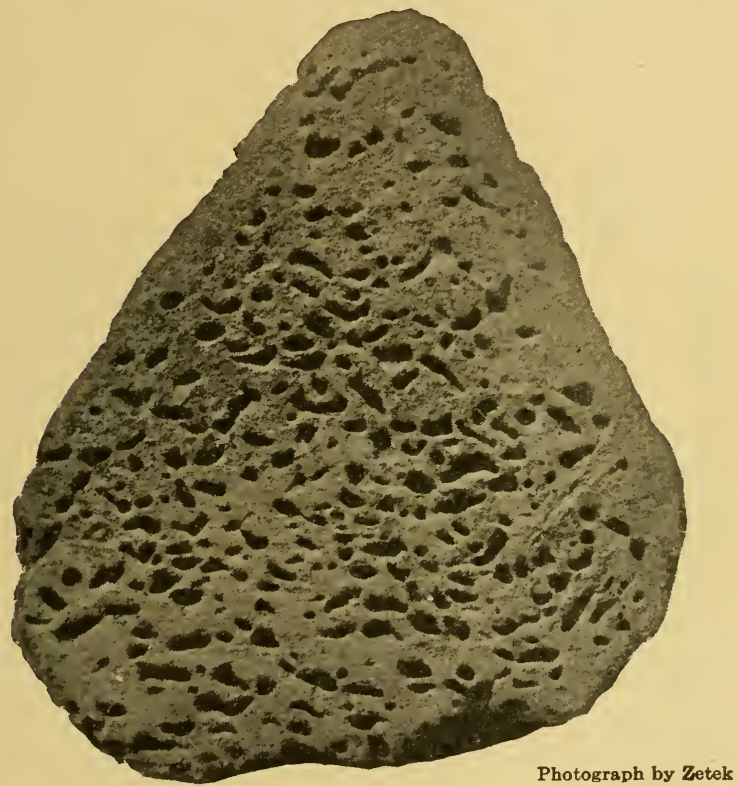

FIG. 38. Cross-section of termite mound nest

Thirty-six kinds of termites are known to live in Panama, and new varieties are still being discovered. Not all of these màke the tree nest I have told about. Some live only in the ground. Others have nests in the wood on which they feed. And still others build tentlike mounds 


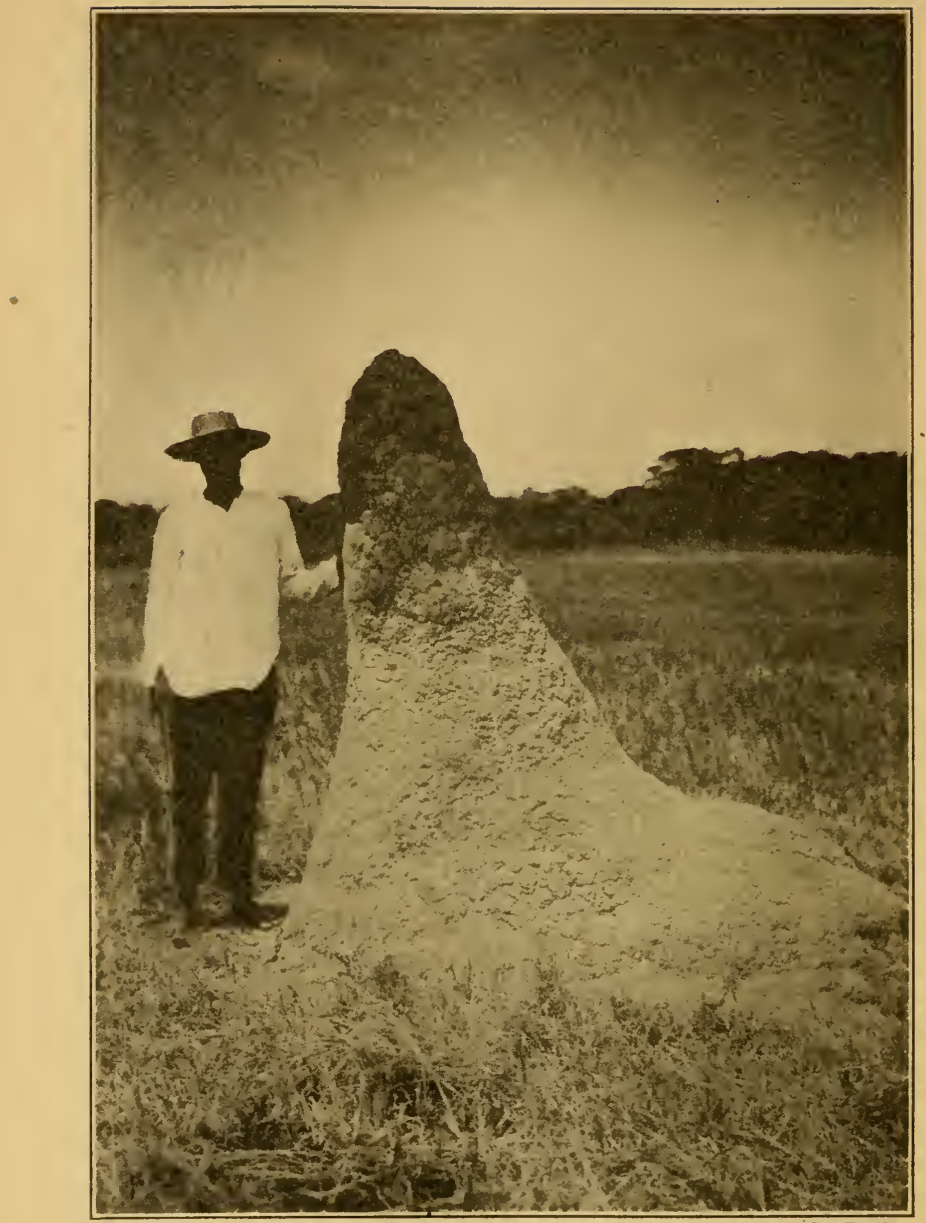

Photograph by Zetek

FIG. 39. Termite mound nest 
(Figs. 38,39 ) of clay out on the plains, until the plain looks like an Indian encampment. These last may stand as high as a man's head.

All of them avoid light, moist air, and wind. They have lived under shelter for so long that their skins are thin and sensitive like a child's that has been too long indoors, and they are nearly or quite blind. The soldiers would not be able to protect their colonies without the help of the strong nests. We have already seen that birds and anteaters feed on them. Ants are an even more terrible enemy.

Sometimes ants come into the termite nest and live there. The termites let the ants have the center of the nest and they themselves go off to the outer rooms. Sometimes they may live in the same nest without disturbing each other, but if they come in each other's way there is a vigorous battle.

I broke into a half-rotted log one day and found part of the tunnels through it taken by ants and part by termites. They might have been living peacefully before, but both were excited by having their runways broken open and the ants began to stalk the termites. They ran up close to the termites and made a dive at them with their long jaws, which I could distinctly hear click as they closed. Usually the first attempt was made from too great a distance. Then the ant would stop, take another start, and grab again. On 
the second trial the termite was often caught and probably eaten.

When I looked at the log again two days later, all was quiet again. The termites were established in one small part of the log, leaving most of the galleries to the ants. When a few ants were picked up and dropped among the termites, they immediately made their escape. I took two soldier termites with squirt guns on their foreheads and dropped them into ant country. They moved slowly while ants came rushing up, darting forward and backing off, clashing their huge jaws.

Seven or eight ants, each one five times as large as the termites, came within an inch or two of the termite soldiers, who had climbed on slightly raised places in the rotten wood and stood there about two inches apart, facing the enemy first in one direction and then in another. The ant confronted at the time would usually drop back, and, though I could not see the termite squirt guns working, I could tell that the ant had been hit by something, for he backed off wiping his feelers.

After much running in and backing out, one ant finally dashed at the side of a termite, bit, and ran. Another ant repeated the same tactics, and the termite rolled off his little hill and lay still. The second termite soldier was killed by the same side attacks. After the two little invaders were safely dead the ants passing them 
would touch them with their feelers, but soon they paid no more attention to the battle ground. The whole affair lasted no more than five minutes. I think it ended only after the termite soldiers had no more sticky liquid left to shoot from their forehead squirt guns.

While this fight was going on I saw other ants hunting the worker termites and carrying them off in their jaws. The termites had a runway near one edge of the rotten log, and though it was no longer covered they were still using it. For some distance the runway followed the side of a tiny ridge. The ants climbed this ridge to a position where they could reach over and touch the passing termites with their feelers. When it had found a termite victim, I saw one ant run out behind it and bite it about mid-body. After two bites here the ant ran around and bit its head close to its jaws. Perhaps this crushed the termite's jaws so that it could no longer hurt the ant. At any rate, the ant was now ready to pick it up and run off with it.

One of the stalking ants touched a termite soldier going by, seized him from the side, and, quicker than my eye could follow, dragged him from his place on the trail, over the little ridge, and threw him down on the other side. The ant turned back to attack the trail again, but this time he met a termite soldier head on and backed quickly away. I watched the robber ants for 
half an hour, but I saw no more soldiers taken from the trail, though many passed.

The termites must have been moving out, for as time went on fewer and fewer workers came along the trail, and at last only soldier termites were left. When this came about the ants went away, leaving the field in the possession of the squirt-gun warriors.

Another day I found a tree termite nest which had also some ant lodgers. The ants had taken the upper and inner parts, where they kept their eggs and babies. When this nest was broken open, some of the ants were accidentally shaken down among the termites. This time the soldier termites went after the ants. When one attacked an ant by himself, he might shoot at its legs, but he preferred to climb on its back and squirt down on it. When several joined in attacking one ant, they gummed him up well with the clear, sticky liquid from their guns. They often overloaded an ant so heavily that he became quite helpless and tumbled to the ground, termites and all.

These battles, you will remember, were between blind ants and blind termites. They were fought by the sense of smell and the sense of touch. Perhaps when the ants and termites live peaceably in the same nest it is because they do not smell each other any more. We say, "Out of sight is out of mind." Their motto may be, "Out of smell is out of mind." 


\section{SPIDERS AND THEIR RELATIVES}

Cholo, a fat little negro who liked to believe and tell wonderful stories, was afraid of forest ghosts and bullfrog hoodoos, but most of all he was afraid of a certain pink scorpion he told me about. These pink scorpions were found on Barro Colorado, Cholo said, but he did not know anybody who had ever seen one. The reason was very simple. The pink scorpion was so deadly that no one had ever seen him and lived to tell the tale. Cholo could not ever tell me why he knew they were pink, but he was as sure of the color as he was of the scorpion.

Of course we never saw this gaily colored and frightful animal, but the story reminded me of other tales I had heard when I was a boy. The grown-up people I knew then were all afraid of spiders, which were the nearest relatives to scorpions that Indiana could boast. They believed that the bite of any spider was poisonous, and they thought, too, that spiders would go out of their way to bite people. This was an entirely wrong idea that took me many years to correct for myself. When we read letters from friends in Mexico who told of finding scorpions in their shoes of mornings, we were sure that they had been in great danger. 
All these boyhood memories came back to me on one of my first days in the jungle when Blanco found a number of half-grown scorpions in a log he was chopping for firewood. He supposed I knew nothing about them and explained kindly and carefully, "Malo, malo - mucho malo," which I guessed to mean, "Bad, bad-very bad." Then, for fear I still did not understand, he pinched one finger between his teeth, then held the bitten finger with his other hand while his face took on a look of great pain and he said in his difficult English, "Bite-a-you-bad!" Such an elaborate warning must have seemed to him quite enough for any sensible person, and he was much concerned for me when I ran over to examine the inch-long black animals and picked up with my long forceps as many as I could find to put away in glass jars for study.

The scorpions are relatives of spiders, but they do not look much like them. The scorpion has a long, jointed "tail" armed at the end with a sting (Fig. 40). The sting is made of two parts a sharp spine at the tip of the tail for piercing its victim and just under this an opening from which poison flows into the wound made by the spine. Its front pair of legs has grown into great pinching claws like those a crayfish uses so well.

In the daytime scorpions rest in dark places like the log where Blanco found them. At night they go out to hunt their prey. Their long 
pincher claws are covered with sensitive hairs. When a beetle or other unfortunate insect touches these hairs, he is caught by the strong claws and held. The scorpion lifts his flexible abdomen and tail rapidly up and forward over his head

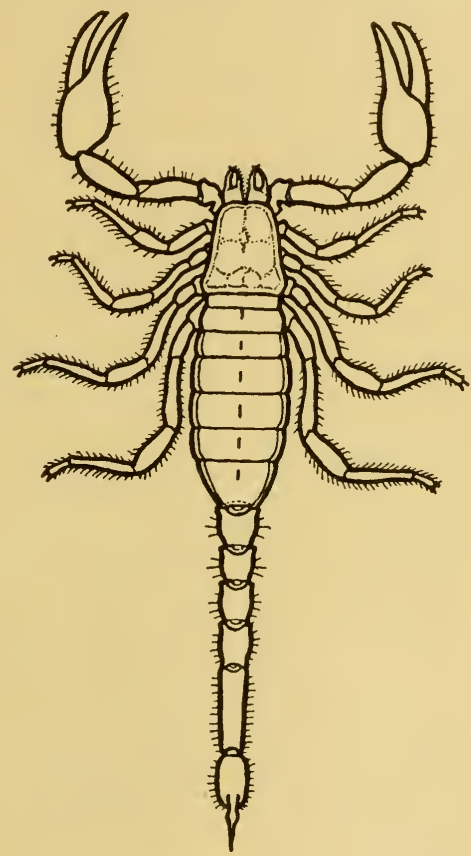

Modified trom Riverside Natural History

FIG. 40. Scorpion

and pierces the body of the insect with the sharp spine. The poison under the spine oozes into the wound and kills the insect. His own poison does not hurt the scorpion's digestion. As soon as the 
insect is helpless he tears it into pieces with his claws and eats the softer parts, poison and all.

The quantity of poison depends on the size of the scorpion. The larger scorpions, which may grow to have a length of eight inches, can kill mice. As far as human beings are concerned, I knew that to a man in good health a scorpion sting is painful, but not dangerous. It aches severely, swells, and throbs as it becomes feverish, but it is not fatal. I did not want a scorpion sting any more than I wanted a wasp sting, but I found the scorpions much easier to handle with forceps at a safe distance than an active wasp would have been. To a person weakened with malaria or some other wasting disease a scorpion sting would be more serious.

Blanco was plainly much worried at my interest in these scorpions, but I had no trouble with them, nor later with others. They do not sting unless they are hunting for food or are attacked, and I was careful not to provoke them. I did not put my bare hand into dark holes, nor under logs. I rolled the logs over to see what was under them and fished in dark corners with my good steel forceps.

Another spider relative found in the jungle and often much feared is the large hairy tarantula, which is also called the bird-eating spider. The plump bodies of tarantulas may grow to be two inches long, and their hairy legs have a spread of 
seven inches. They live in natural holes in trees and in the ground, and these nests they line with a web as many spiders do. Sometimes they ride north on the ships in bunches of bananas, where they are neither happy nor welcome.

One day I had climbed my spiked tree and was working there when Santiago called to me from the ground to come down in a hurry. It was not very easy to get up speed when I was so well loaded with expensive apparatus, but I let myself down as fast as possible. There I found Santiago excitedly holding down a big wasp while a tiredlooking tarantula lay near by. Santiago had been hunting around at random for animals when he spied this tarantula climbing up on a slanting stick until it reached the tip a foot or so above the ground. There it settled down quietly, probably waiting for some animal which it could catch and eat to come along. It gets its name of birdeating spider from its ability to catch and kill small birds once in a while.

While it waited, another hunter came along. This was a large wasp, a really monster wasp an inch and a quarter long. The wasp swooped on the tarantula, seized it, and stung it and was dragging it off when Santiago interfered.

The wasp, commonly called tarantula hawk, was dead and there was nothing to do but pickle it. The tarantula was still alive, but paralyzed from the wasp's sting until it could not move. 
I put it away in an unventilated can to see how long it would live. The photograph given (Fig. 4I) was posed four weeks later. The dead wasp has been propped up on her stiff legs as well as

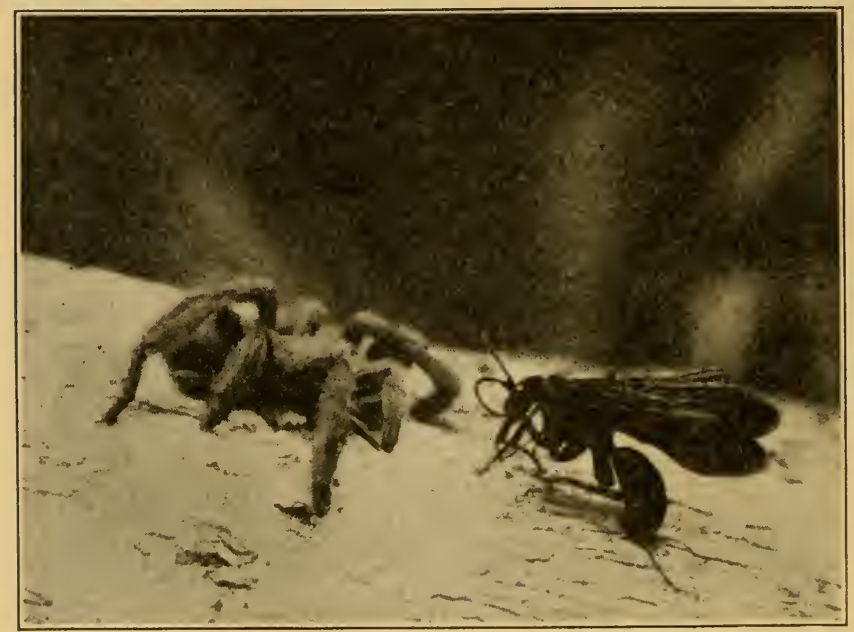

FIG. 4I. Tarantula and tarantula hawk

possible, but the tarantula, which is still alive, can be much better posed because his legs, though almost helpless, are still flexible. In fact, he could still move them slightly.

The tarantula lived thirty-five days in his can. If he had been taken away by the wasp he would have lived as long, unless he had first been eaten. The wasp had near by a hole which she had carefully prepared for a nest. There she meant to drag the tarantula and lay her eggs on it. 
When the eggs hatched, the wasp babies would feed on the still living tarantula until they had grown large enough to spin cocoons for themselves. The wasp mother had no refrigerator, and this was the way she arranged for her children to have all the fresh meat they needed.

I wish that Santiago had let the tarantula hawk live. I should have been interested in seeing her drag the heavy tarantula to her nest and pack it away there as preserved meat. I have seen wasps farther north do the same thing with spiders and caterpillars, but never any so large or so easily studied.

People have puzzled a great deal over the instinct that leads young wasps, freshly hatched from their cocoons, to hunt always for the same kind of animal on which to stow away their eggs. They never see their own mother to learn from her, nor do they have any older wasp to watch, but the young tarantula hawk never makes a mistake. She always selects a tarantula on which to lay her eggs, just as the northern wasp will always find the same kind of spider or caterpillar on which she has grown up, for her own children to eat.

The answer is probably this: The tarantula hawk has been brought up on tarantula. As a youngster she never ate any other food, so that the smell of nothing else attracts her. Flying through the jungle, she sniffs tarantula odor and she 
straightway goes to it. It is the most homelike smell in all the jungle to her. When she finds the tarantula and has it safe, she is ready to lay her eggs near by.

Tarantulas can inflict a very painful wound which might be fatal to a person not in good health, but I did not hear of any one being bitten by them in the tropics, and no one mentioned being afraid of them.

As for the spiders themselves, they were abundant, prowling about among the stones and leaves and spinning their webs in the shade, but they were dull colored and, curiously enough, I could find them most easily at night. When I put a headlight on my hatband and walked slowly along the trail, little sparks of greenish-blue light gleamed back at me wherever the light struck the ground. These puzzled me at first. I thought they must be dewdrops, but each one that I stalked and caught I found to be a spider, whose eyes reflected the light like diamonds. They were as abundant as fireflies on a summer evening.

These spiders never attack people, and I doubt if their bite would be felt more than a pin prick. I was grateful to them for their constant killing of troublesome insects. There are so many of them that they must dispose of a great many mosquitoes and other nuisances.

One of the oddest spider relatives that I saw was the harvestman (Fig. 42), which we call 
granddaddy-long-legs. This is a ridiculous looking animal with a tiny round body like a small dark seed, balanced on eight long, hairlike legs. His legs are very useful to him, carrying him along on great strides, although he cannot scurry

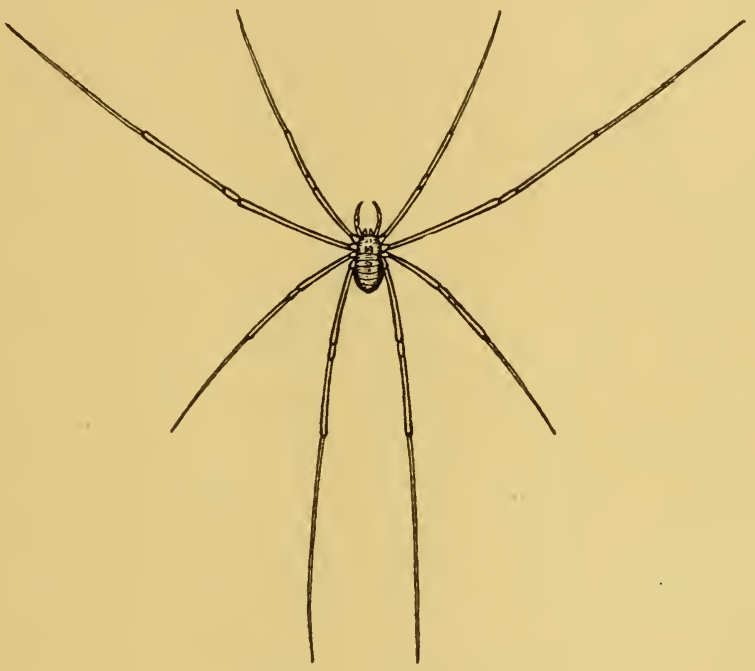

FIG. 42. The harvestman

so fast as a spider. I found one afternoon that he had another use for them as well.

We were working down my shady little brook, turning over stones and dipping into the pools to see what we could find, when I saw under the overhanging bank a large dark speck, dancing up and down like a giant dust mote in a sunbeam. As I waited, it waved to and fro more slowly 
and came to rest. Then I could see that it was the body of a harvestman, which had been springing up and down so fast that its legs were invisible, like the spokes in a rapidly moving wheel.

I came closer to see more clearly in the halflight of the shaded ravine, and suddenly a whole group of the dark bodies began dancing. Their feet did not move from the spot. They swayed up and down like a child bouncing on bed springs. When their bodies were moving they looked to be free in the air, but when they became quiet I could see that each was supported by its long legs and that the legs of each harvestman touched the legs of its neighbor. When one was disturbed, the movement of his legs sent the news along the legs of all the rest and they danced together. The whole colony spends sociable days in this cool, quiet retreat, and with their scheme for making themselves invisible they are fairly safe, even though there are so many of them.

The long legs serve well at another time. When the army ants set out hunting, all animals that can move come flying, crawling, and leaping out of their hiding places. But if they escape the ants they are in as great danger from the birds that follow the ant column to pick up the leftovers. In the midst of the confusion the harvestman stands still. He lifts first one foot and then another as an ant scout comes too near that particular leg. His little round body is swung 
well above the ants. His legs are so slender that the ant does not easily blunder against them, and, if necessary, he can lift five of his eight legs at once and balance on the other three. It is seldom that he cannot find clear space for three legs while the others are held up out of harm's way. At the same time the harvestman is safe from the birds that follow the ants, since the birds are careful not to come too close to army ants.

The spider relatives in the jungle that everyone talked about and detested were neither scorpions nor tarantulas. They were the tiny red bugs that are relatives of our northern chiggers, and the somewhat larger ticks, which are like the wood ticks we find in our own woods.

It is hard to say which of the two pests is the more troublesome. The red bugs, which are so tiny that they can barely be seen without a microscope, could be somewhat discouraged if one sprinkled one's skin with yellow, sneeze-producing "flowers of sulphur" while dressing in the morning. When they did succeed in burrowing under one's skin in spite of the powder, they produced an itching spot that demanded to be scratched whether scratching was convenient or not.

I did not find any sure way of keeping off the flat brown ticks. In January when I first reached the jungle I found a crop of small newly hatched ticks over all the plants. They waited hopefully on nearly every leaf, stretching out their forelegs 
to catch on any moving thing that brushed by. These were called seed ticks. They are tiny things that can get through anything short of leather. I have found as many as fifty on one forearm. Fortunately they have the habit of wandering about over the skin for some time before settling down to bury their heads and suck blood, and it is at this time that they can be most easily removed. If they are allowed to settle down and stay, their bodies swell surprisingly with blood. I have seen them a half-inch and even, more across.

The sure and slow way is to pick them off by hand one at a time. The wholesale treatment is to rub down one's body with kerosene, follow this with a heavy lather of soap and water, and polish off with alcohol. Even after this program I have found the larger ones hanging on, and ther the only thing to do was to ask some one to take them off in return for a similar favor.

The best practice I found was to go ahead as if there were no ticks around as long as possible and then pick them off and go ahead again. The negroes took their spare time for looking over themselves and one another quite as a matter of course. But I never quite reached the place where I was not somewhat embarrassed to sit in the first-class coaches of the Panama railway of an evening, picking off ticks that rambled across the back of my neck toward my hair. 
The red bugs and the ticks are real nuisances. If one were out in the jungle for a long time with no good way of getting rid of them at least once

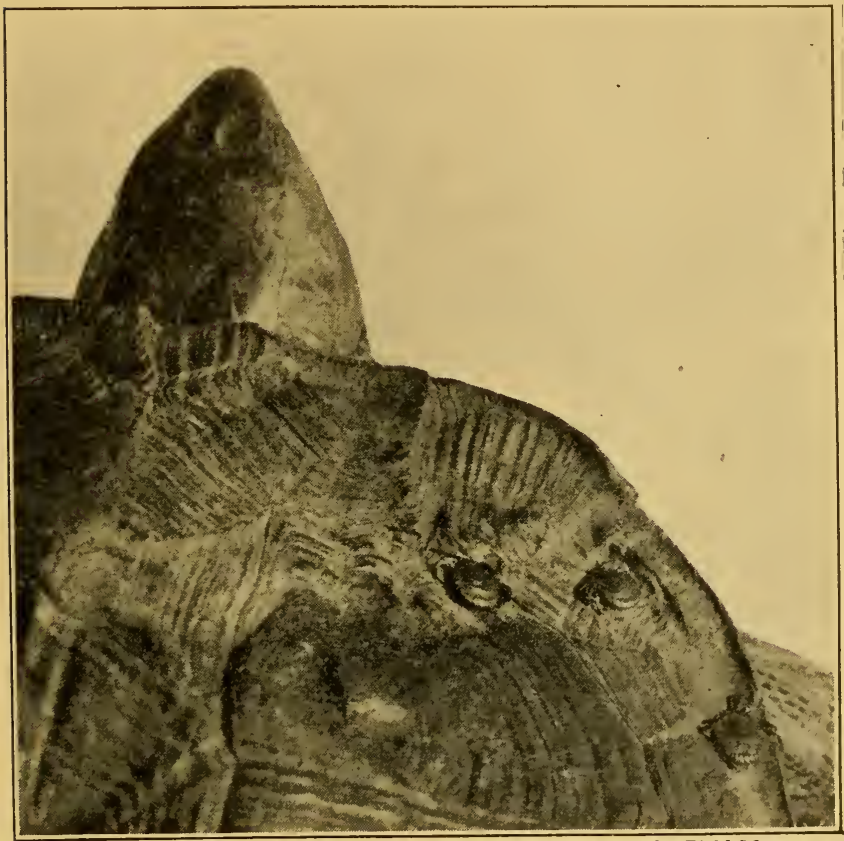

Photograph by Field Museum

FIG. 43. Ticks feeding through turtle shell

a day, he might be driven nearly distracted. Both trouble other animals beside man. The large tapirs are said to be covered with them. One of the turtles I found had not only ticks attached to its leathery legs, but others as well fed that had gone to the work of boring through its hard 
shell. Figure 43 shows them on the shell about their real size. These are the same kind that attacked me. A soft-skinned person must be a very juicy morsel to animals that can successfully feed through a turtle's shell.

The ticks are a great hindrance to cattle growers. Fresh milk on the Canal Zone costs thirty cents a quart, so that most people use dried or condensed milk instead. This is because the good milk cows we have in the north cannot live in the pastures of Panama on account of the ticks. The ticks not only weaken the cattle by sucking their blood, but they carry a disease that kills many of them. The cattle grown on the ranches owned by the government on the Zone are of the small native breeds that do not suffer from disease as the better northern cattle do. 


\section{PERIPATUS, THE MOST INTERESTING ANIMAL}

Pe-rip-a-tus sounds like the answer to a charade or a puzzle, and you may think that it really is a puzzle when I tell you that of all the animals on Barro Colorado Island my naturalist friends ask first about it. "Did you really see Peripatu? ?" they ask. "Is it found on the island? If I went there do you think I could find it?"

I wonder if you ever heard of it before. Peripatus is not found in great numbers like the ants, nor is it clever about its work, as they are. It is not poisonous. It does not destroy property, like the termites. It is not beautiful. It has no market value, except as a pickled specimen on a museum shelf. And yet to many people it is the most interesting animal on the island.

This is the reason: Peripatus is neither a worm nor an insect, but a little of both. It is a sort of connecting link between the two great groups of animals. The centaur that the old Greeks imagined, with the head of a man and the body of a horse, was not nearly so queer a combination as Peripatus.

It is a very old family. Millions of years ago the still older family of worms were changing the style of their bodies a little. From the outside 
they looked much the same, but on the inside of their bodies they tried new ways of breathing air and pumping blood. They were no longer real worms, but neither had they changed enough to be called insects. They were Peripatus. In rocks that geologists think were laid down about eight hundred million years ago we find today the print of Peripatus bodies very much like those that live on Barro Colorado Island now.

In those ancient days, when all the earth was warmer and moister, Peripatus could probably be found over a great deal of the world. Now the family lives only in the belt around the middle of the earth, in South and Central America, the West Indies, Africa, the Malay Peninsula, the East Indies, and Australia.

On Barro Colorado, Peripatus is hard to find in the dry season. Whenever I had the time to spare I dug for the animals in likely places, but I never brought any up to the light. I was fortunate enough to see one that had been found by a man digging out termite burrows.

This Peripatus had a wormlike body, about an inch and a half long, with rows of fat legs ranged in pairs along its sides, like the legs of an ordinary caterpillar. Its light-brown velvety skin had a darker stripe down the back. The eyes on the sides of its head were small and bright. Above its eyes it carried a pair of antennae, or feelers, nearly as long as the Peripatus itself, and these 
antennae it could push farther out or shorten when it pleased.

Since Peripatus like neither the light nor dry air, they burrow deep in the loose moist ground under old logs when the dry season comes on. In the rainy season they come out at night and may be seen by a flashlight as they move over their logs. Like earthworms, they are able to crawl backward as well as forward. When disturbed, their smooth muscular bodies contract suddenly and they squirt out small drops of sticky slime which clings to almost everything it touches except their own velvety skin. Perhaps this bombardment frightens enemies away, and perhaps, like the sticky stuff in the termite's squirt gun, it helps to gum up the legs and wings of the animals they hunt, so that they cannot easily escape.

When they are taken into the laboratory for study they can be fed on liver or flies. It is well to remember to put only a few of the same size in a cage, for they will also eat each other. I heard the sad story of a man who managed to collect fourteen grown Peripatus and twenty young. Before he realized what was happening only three were left. Those three had eaten all the others.

The eggs are very fragile and the mother carries them inside her own body until they are hatched out. When the little Peripatus are born they are like their mother in every way except that they are smaller and not so dark. She does not take 
any further care of them. They crawl away and find their own food.

From Figure 44 you can see the long, wormlike body, but you cannot see that the legs are hollow as they always are in legged worms. The hidden arrangement of muscles under the skin fits the needs of a soft-legged worm, but would never do for a hard-shelled insect.

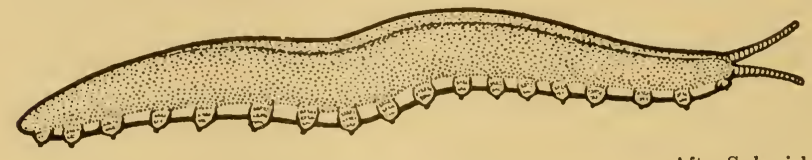

FIG. 44. Peripatus

After Sedgwick

The jaws grow like those of an insect, but Peripatus has only one pair of jaws and most insects have more. Peripatus has a real heart, which the worms have never had. The heart is built like that of an insect, and so are the air tubes with which it breathes. Worms breathe through their soft skin or by tiny gills on their legs or heads.

This insect-worm combination seems to be an experiment that Nature tried once and found neither poor enough to throw away entirely nor successful enough to become important and widespread. From other experiments came the true insects, and many failures must have died off. Our great reason for being interested in Peripatus is that it lives today and shows us what that old experiment was like. 


\section{SNAKES AND CROCODILES}

Everyone asks me about the snakes of the jungle, and I must admit that they were the animals I most feared in going into the tropics. On the big boat that took me from New Orleans to the Canal Zone I heard some hair-raising snake stories, but it was encouraging to find that the tales of men killed by snake bite while digging the Canal grew less terrifying the nearer we came to the Isthmus. At New Orleans I had been told that hundreds died. At Colon they said that there had been a few snake-bitten men. But I found only one person who actually knew of such a case, and he assured me that the man recovered from the effects of the poison.

My reading and my common sense had told me all this before I left the north, and I had planned to wear rubber-soled tennis shoes and canvas leggings in the jungle, as being noiseless and light. However, a friend who studies snakes and who had spent some time in Central America advised heavy shoes and leather puttees. He said quite frankly that he had spent nearly half a year looking for poisonous snakes in the Central American jungle, and that he had not found half a dozen in all that time. But he told me also that if I should happen to run across a poisonous 
one it was likely to be very poisonous, and, what was more serious, it would not give warning of attack, as our rattlesnakes do.

My first snake experience on the Canal Zone came on my first day there. I had gone to the office of a physician in the Ancon hospital to ask when I should begin to take quinine to prevent malaria. He took me into a large adjoining closet to show me some jaguar skulls and birdskins and I bent over to look. Presently he called my attention to a shelf close to my forehead, and there in the half-darkness lay a live boa constrictor, so large that it was hard for me in my excitement to tell how big it was. Whatever its actual length, it was large enough to swallow full-grown chickens for a meal, though the physician was complaining that he could not get it to eat at all and he was afraid that it would starve. Boa constrictors are, of course, not poisonous and they are seldom dangerous to people or large animals, but the experience left me a little nervous.

A few days later a physician on the Atlantic side sent me by messenger a can containing, so the label said, two live tree vipers. These are really poisonous snakes, whose lives are spent in trees. They use their slender tails in climbing, as a monkey uses his, clinging to limbs. Sometimes they are found in bunches of bananas which give them an excellent hiding place. 


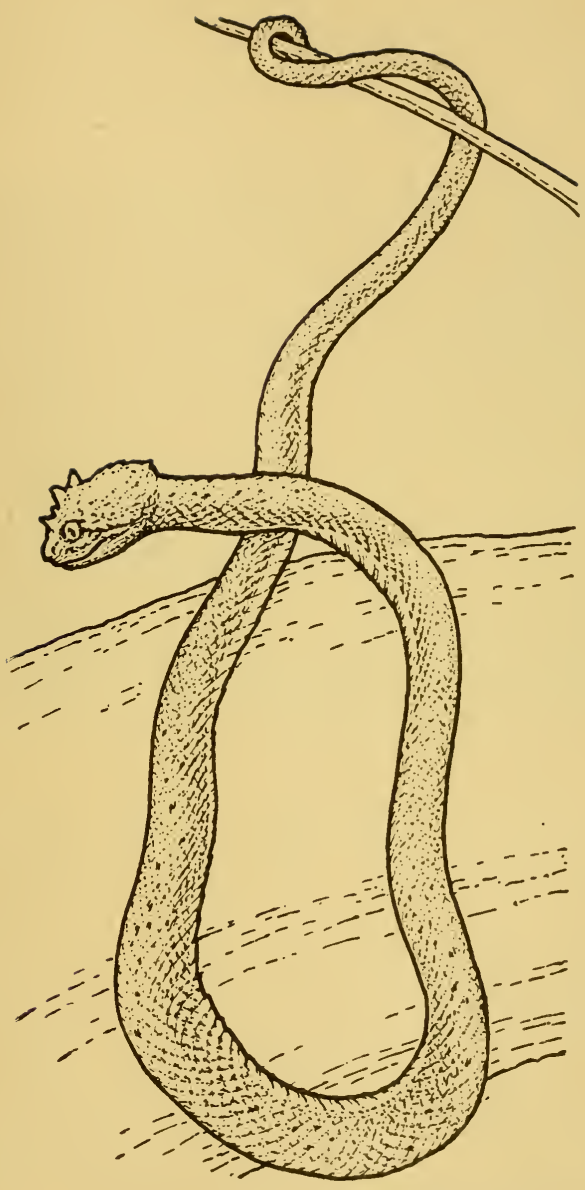

After photograph by Ditmars

FIG. 45. Horned palm viper 
When the vipers were transferred carefully to a wire cage they were seen to be nearly half grown. The grown snake reaches a length of three feet. A glass dish for water had been placed in one corner of the cage where it could be filled without opening the cage. We gave them grasshoppers, various bugs, and bits of meat, but, like many snakes in captivity, they refused to eat. They usually stayed coiled, with their flat, arrowshaped heads, all too heavy for their slender bodies, poised and alert to strike.

These vipers are relatives of the dreaded fer-de-lance and bushmaster, much larger poisonous snakes found more commonly on toward South America. I was told of an airplane relief party recently sent from Ancon to the interior of Panama with antitoxin to treat a man bitten by a bushmaster.

These snakes and snake stories did not make my dreams the most pleasant the night before I first went to Barro Colorado. I carried in my knapsack, as a matter of course, a bottle of potassium permanganate and a sharp razor blade, and I knew that in case of a bite I must make a crisscross cut at the bitten place, after having first bandaged tightly above it, then suck out the poison and rub in the potassium permanganate, all of which sounds simple enough.

As a matter of fact, I did not see any snake that first day, nor yet the second. It was not 
until noon of my third day that I stumbled across one. With Molino I was picking my way up the dry bed of a rocky run, machete in one hand, camera and notebook in the other. I chanced

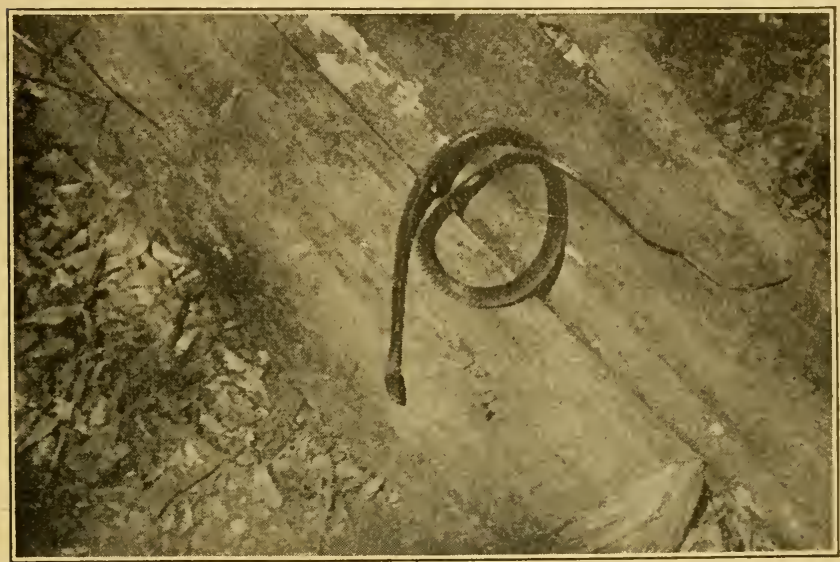

FIG. 46. The biggest snake

to slash away a great hanging leaf, and there I saw a fairly large snake, six feet or more long, in the shade.

Instinctively I drew back long enough to see that he was not poisonous. A bushmaster would have shown brilliant black blotches on a reddish yellow background. This snake had a plain dark skin with a bluish sheen. Molino pushed forward and struck him a smart blow on the head with his machete, but the snake was not even stunned. He crawled slowly but surely out of sight under an overhanging rock. 
More enthusiastic snake collectors would have taken energetic measures to catch him, but I was content to watch him ripple away. Later I shot

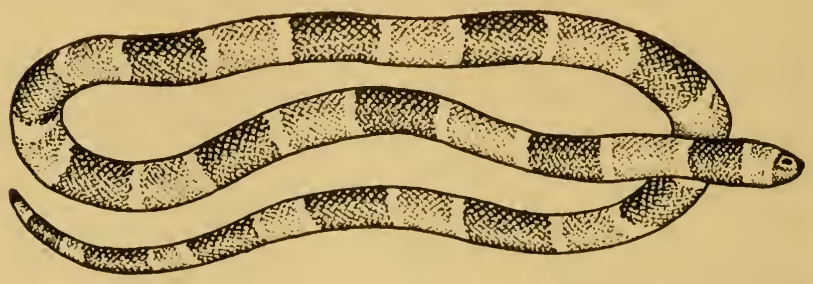

Fig. 47. Coral snake

After photograph by Ditmars

one just like him behind the little camp shack, and found him to be a relative of our northern black snake and no more dangerous. His picture (Fig. 46) was taken on so big a log that he does not look as large as he was.

This was the dry season and snakes were scarce. Santiago brought me two coral snakes (Fig. 47) which he had found under dry logs near Frijoles. These are the commonest poison snakes of the Canal. They are beautifully marked with red, black, and yellow bands running entirely around the body. The colors are much the same that the Indians use in cloth and pottery.

Coral snakes are not much feared by the natives, for they will not strike at a passing object, and are roused only when touched or stepped on. Even then the hollow fangs through which their poison flows are so short that canvas 
leggings over ordinary clothing will give complete protection. My native helpers went about barefooted or wearing rope or leather sandals as they pleased. Their ankles were always bare, but they were not afraid of these snakes.

One day while I was working up in my spikeladder tree, I had my men collecting ants and whatever animals they could find near the tree trunk. Cholo, an excitable little negro, who was exploring in the center of wild pineapple plants near by, ran over to the tree and called me to come down and see the snake he had found. All coiled up in the protected bud-center of the plant, sheltered by the larger leaves, was a mildly poisonous snake called the blunt-headed snake (Fig. 48). I could see its body, glistening with

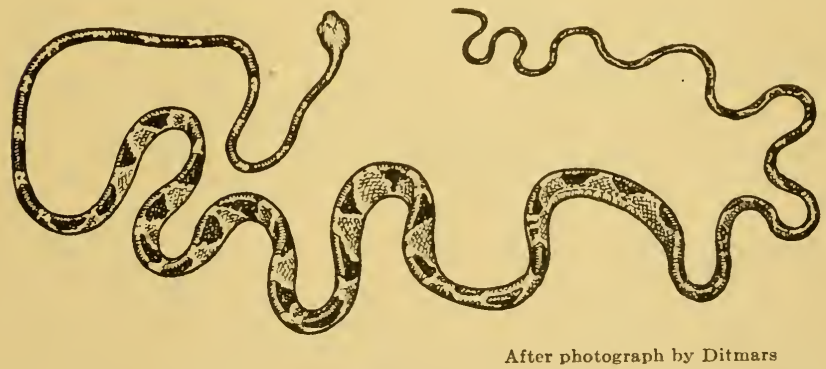

FIG. 48. Blunt-headed snake

moisture, but the broad head was hidden under the body coils and the slender neck looked much like the equally slender tail. 
As it persisted in keeping its head out of sight so that I could not pick it up properly by the neck, I finally shook it out of its resting place two feet above the ground into a bag held ready.

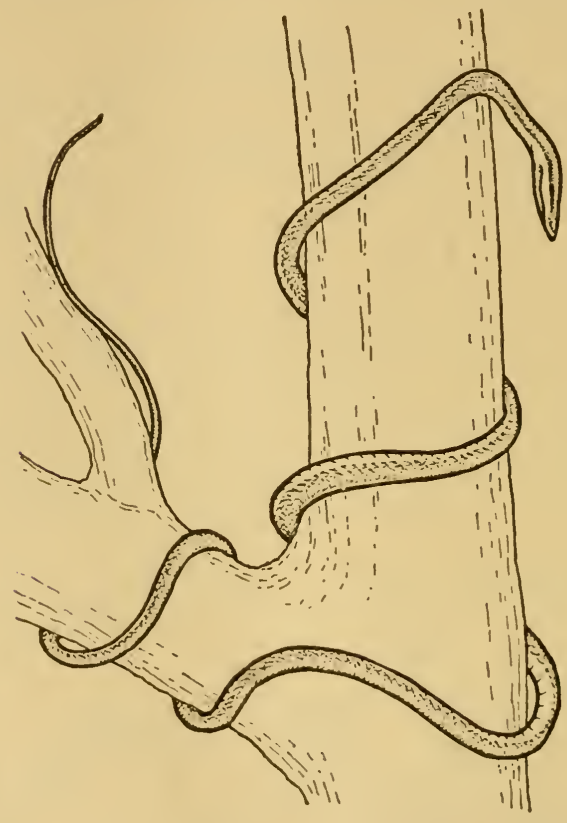

After photograph by Ditmars

FIG. 49. The long-headed tree snake

Then I caught its neck with my forceps and put the head into a bottle of formalin. The long slender neck, the heavier body, and the delicate tail followed, and when the bottle was corked, I had caught my first jungle snake. 
We caught only one other snake that was even mildly poisonous. This was a long-headed tree snake (Fig. 49). During my entire stay in the jungle I met no really poisonous snakes.

We usually think of a poisonous snake as being short and stout-bodied with a broad head. Both the blunt-headed snake and the long-headed snake had long, whiplike bodies, and only one had a broad head. As a matter of fact, not nearly all broad-headed snakes are poisonous, nor are all poisonous snakes broad-headed.

The truly poisonous snakes have fangs like hollow needles through which the poison runs into the wound they make. The mildly poisonous snakes have poison grooves on short teeth so far back in their mouths that they cannot strike with them. A small lizard which can be crammed well back into their mouths can be quickly poisoned when it is bitten, more quickly often than by the other snakes which men fear more.

The snakes go into hiding in the dry season, but they appear again, oddly enough, before the wet season has begun, just as the trees that shed their leaves begin to leaf out before the rains come. In March I saw four or five snakes in one day. These were small and harmless, like our garter snakes in size and behavior.

The tropical snakes that I handled did not have the cold, clammy feeling that makes our snakes disagreeable to the touch. They were 
nearly as warm as I was. The reason is simple. Their temperature is the same as the air around them, or the ground over which they crawl. A snake lying out in the heat of the tropical sun may have a temperature of a hundred degrees. He will be just as warm as the sunshine is. This is one reason why snakes, as well as ants and termites, thrive better in the tropics, where they are not obliged to lie stiff and still through the winter.

Even in this warm snake paradise, everything is not pleasant for them. They are commonly attacked by the army ants, by birds, and by other snakes. I even heard of a snake whose tail was so covered with blood-sucking ticks that he was mistaken for a rattler.

Snakes make their home in the thick layer of palm leaves that thatches the native huts, and live there on the other little animals, the lizards, rats, and mice that find the thatch a convenient hiding place. John English likes to tell of the time when he fumigated a hut like this where he was living. There were too many bugs and larger animals for his comfort, and he decided to use sulphur fumes to drive them out. This hut was a grand one, with walls. After it had been closed all day he aired it out thoroughly, and when the sulphur smoke was gone the family went to bed. In the night he was wakened by a thud on the floor and there he found a big boa 
constrictor that had fallen out of the palm thatch, still stupefied by the sulphur.

I should not feel as untroubled as John English did about sharing my roof with a snake. But I must confess that when I made up my mind that it must be a snake that was carrying off crocodile eggs night after night from the table beside my bed, instead of the rat that I first believed it to be, the idea did not disturb me any more than if it had really been a rat.

I do not think that one needs to fear the snakes on our jungle island. Probably coral snakes and even bushmasters are there, but in two months I found none, although my men and I turned over logs, as well as every loose stone in the stream bed near by. I crawled through underbrush on hands and knees, lay flat on the ground watching animals, climbed my tree regularly, and tramped about as freely as I have ever done in my native Indiana woods. In all that exploring I managed to see twelve living snakes in the jungle. The two that were slightly poisonous were not half so dangerous as the copperheads I. found and killed when a boy.

Personally, I was much more bothered by the crocodiles in Gatun Lake than by any snake. The island inlet was a pleasant shady stretch of clean water (Fig. 50). No spot could have been more inviting for a swim and a bath in the late afternoon of a hot jungle day, except for one 
important item. I knew that a big ten-foot crocodile liked that inlet, too. Sometimes I saw him, floating like a $\log$ at the edge of the water. Sometimes he moved on up the little creek as our boat landed. But even when he was out of sight he made swimming a little too exciting to be worth trying, particularly when I knew that the marines stationed on the mainland near by were under orders not to swim in the lake. It should be added that there are tropical workers much more experienced than I, and no hotter or more anxious for a bath, who take a daily swim regardless of crocodiles.

A number of these crocodiles, which the natives called alligators, were to be seen in the quiet bays along the margin of the lake. One of them I saw day after day from the train window as I commuted from the jungle back to civilization in Ancon. My men brought me big, blunt-ended crocodile eggs (Fig. 5I) which they found near the lake shore in February.

It is not likely that there were many crocodiles in this stretch of country before the lake was made. They are known to live in the deeper holes of rivers, but they prefer to live in lakes. Along rivers they are usually solitary and scattered, but in lakes their numbers increase rapidly. In Gatun Lake they have increased so fast that they have driven their smaller relatives, the caimans, back up into the pools of the little 


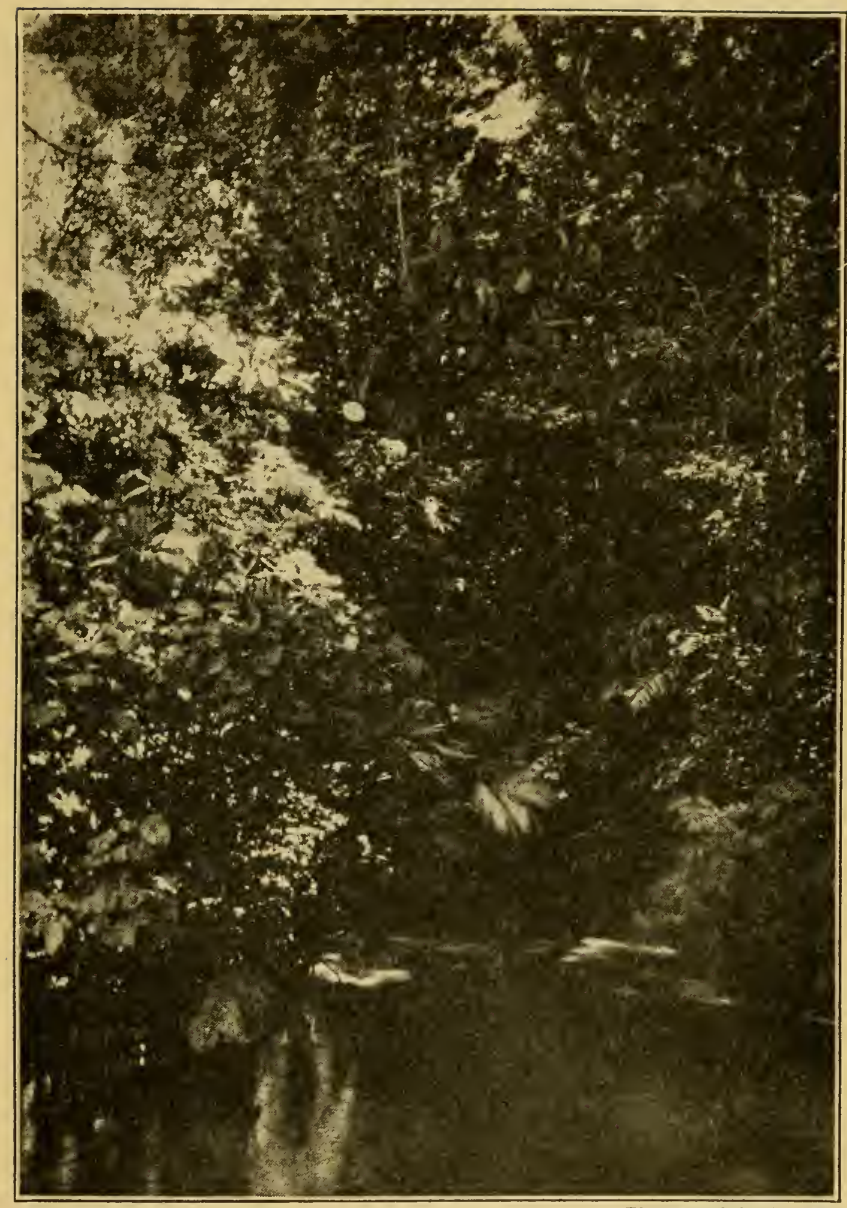

Photograph by Zetek

FIG. 50. The home of the crocodile 
creeks. The caimans are used to stream life as they once found it along the Chagres, and it is likely that there are fewer of them here now than

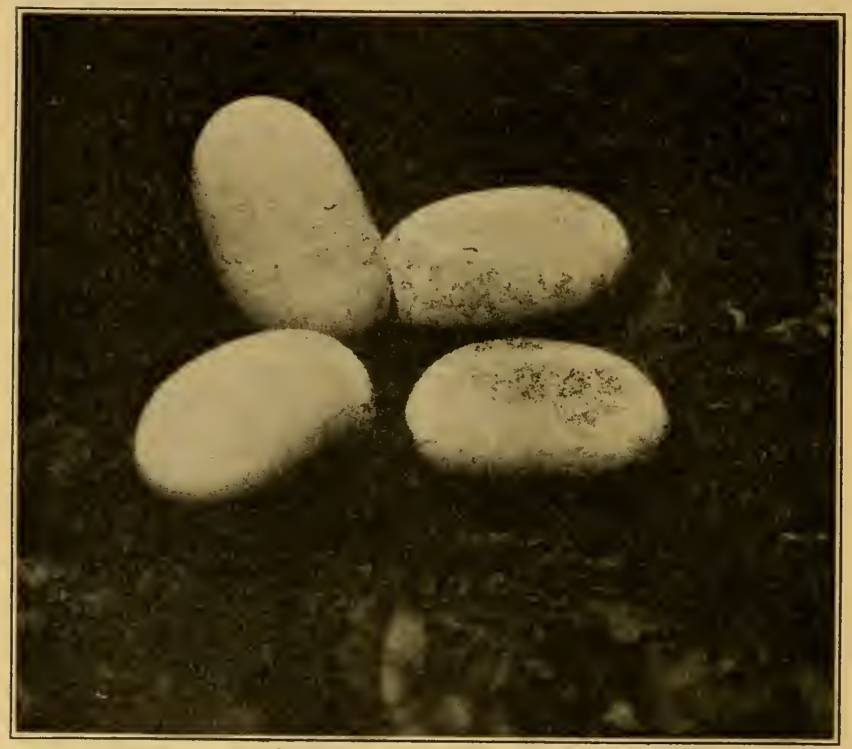

FIG. 5I. Crocodile eggs

in the old days before the river bed became a lake. The large crocodiles eat the caimans that do not get out of their way, and they also eat the smaller crocodiles.

Blanco, Necto, and I were tramping across the island one day looking for large animals. We came to a shady pool in the bed of a stream that was otherwise nearly dry. This was about a 
quarter of a mile up from the lake. The pool was about a rod long and in the widest place four feet across. In the deepest spot there might have been two feet of water. There, lying with his head at the surface well out in the open, we saw a five-foot caiman.

I made ready to shoot him with my light rifle, since I wanted very much to take back his head to a museum, but both the men whispered, "No! No!" so I watched to see what they would do. Both took off their sandals and tightened hold on their machetes. Blanco stole softly around until he was behind and just over the unsuspecting reptile. With one blow he cut into its brain, and then Necto waded in and brought it out to dry land. I tried several photographs with my

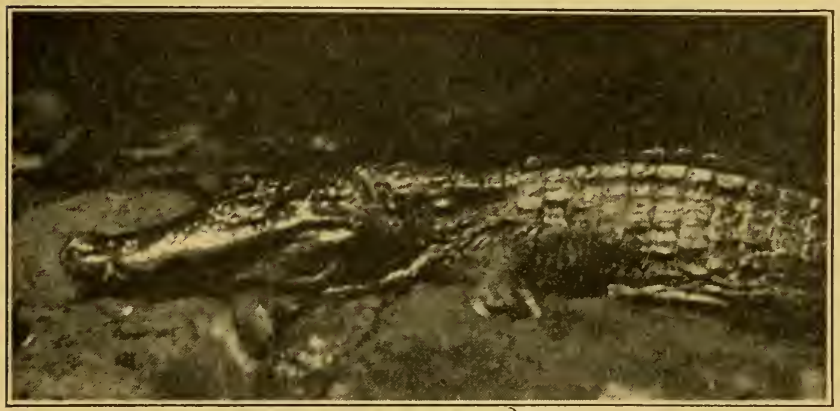

FIG. 52. The caiman

big camera, moving the caiman into the brightest sunflecks to be found under the dusky jungle roof, but I only proved again that there is seldom 
light enough on the forest floor for a good picture. The photograph given (Fig. 52) is the best of a poor lot.

In the pool were several fish, eight inches long or less, on which I suspect he depended for food.

The caimans are related to our Florida alligators. Like the alligators, they lay their eggs in heaps of rotting leaves and twigs, which serve to keep the eggs moist and at about the same temperature. Crocodiles bury their eggs in the ground. Caimans are found as far north as southern Mexico, and they spread far into South America, where they live in great numbers along warm, quiet rivers and swamps of the rainy tropics. 


\section{THE ANCIENT FAMILY OF LIZARDS}

The lizards more than made up for the scarcity of snakes. They were abundant and of many different kinds. None of them was poisonous. It seemed to me, as I watched them climb bushes and trees, hop along the ground, or skip over the surface of the lake, that I might be living in the Age of Reptiles, when they were lords of the world and there was neither man nor any of the hairy, four-footed animals to be found. But I had to remember that in those old days some of them were so huge that I should have scuttled away from them as swiftly as their small very-greatgrandchildren slipped away from me now.

The ancestors of these very lizards were living back in the years when the great coal beds were being laid down in hot forest swamps, and many geologists think this happened more than five hundred million years ago (Fig. 53). Coal miners dig up their bones now with the coal, and in the earth layer just above the coal they find the bones and footprints of huge lizard-like animals, a hundred feet long and weighing several tons. Sometimes they were large and sometimes they were small, but always there were lizards to be found in this warm region. When the land sank and the sea came in they moved back. 
When the land rose above sea level they spread out over it again.

The lizard family is so old that it makes even the ants seem rather new. From it have come not only the tremendous old dinosaurs, but also the snakes, turtles, alligators, and crocodiles.

I hope that as you read you will not only see these lizards as they look today, but that you

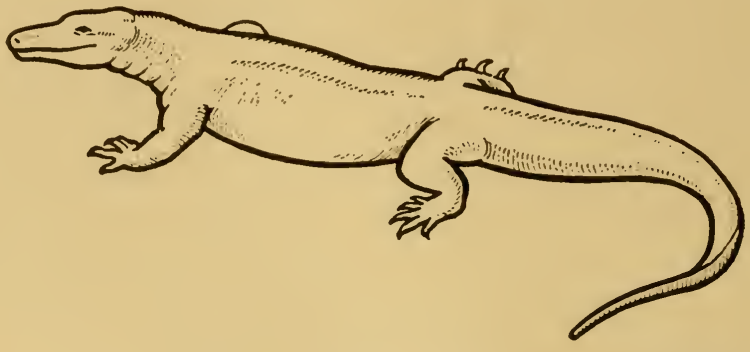

FIG. 53. Ancient lizard

After Lull

will imagine some of their interesting habits being learned gradually in this long, long stretch of time.

In less than a week from the time I saw my first tropical jungle I was living alone on Barro Colorado with no one nearer than an hour's paddle across the lake and no boat to take me there if I had wished to go. When I had come to the island before, some one was always with me and we were always in a hurry to get back into the jungle to see some special thing. Now that my boatman had gone back to Frijoles and I was alone and quiet, the smaller animals began 
to go about their business again, and I had nothing to do but sit in the door of my shack (Fig. 54) and see what I could see.

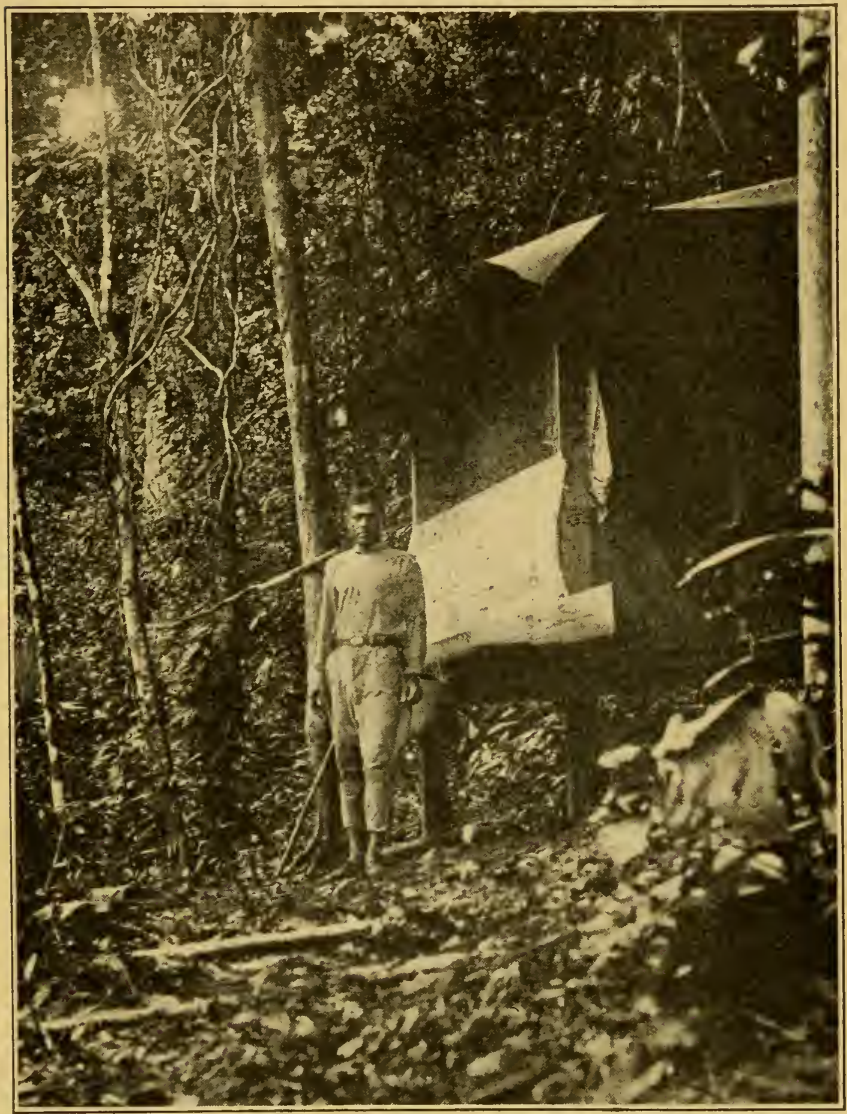

FIG. 54. The shack

Photograph by Lutz 
The crazy little board shack was set about fifty feet up the hillside, by the cleared trail, on a shelf not so steep as the rest of the hill. There was a little footpath running to a near-by brook where I got my drinking water. The rest of the hillside was a tangle of green trees, shrubs, and vines. Among these I knew the palms and the broad-leaved heliconias, but the other plants had never got into any greenhouse I knew, nor been named in any picture book of my acquaintance, though I grew to know many of them later. They made a strange green frame for the long inlet, and it only made me feel even farther away from home to catch once in a while a glimpse of a great ocean freighter sliding quietly past far out in the lake.

The first moving thing to catch my attention in this unfamiliar picture was a little Anolis lizard, hopping across the open space like Old Man Kangaroo, thirty inches to one hop. He started to climb a near-by tree and I made after him with a net in one hand. I peeped around the tree, holding the net on the other side of the tree in case he ran. He did not run. He kept his small bright eyes on me and dodged the clumsy efforts that I made to catch him with the net around the tree.

In California I had caught rock lizards in my hands, and I tried that plan on Anolis now. My open hand struck the tree where he had been 
without touching him, but to my surprise he fell to the ground as if he had been stunned and lay there perfectly stiff. When I picked him up he was still stiff, but I noticed that he had fallen as if by accident under a leaf to which one claw still clung carelessly. With my free hand I fumbled for a bottle and found the cork hard to pull out. All this time Anolis showed no sign of life. When I thrust him head first into the bottle his hind toes caught on the top, again as if only by accident.

Nothing else had showed me that he was still alive, but these two accidents would have been enough to make me suspicious, even if I had not known all the time that he was a very much alive lizard playing dead in the hope that I would let him go.

Once he was safely bottled I had plenty of time to examine him. Of Anolis' five-inch length, about two-thirds was tail. Since his head and mouth look something like an alligator's, one of his names is alligator lizard. Like the kangaroo, his jumping hind legs were long and his front legs short. All his twenty long toes were fitted with vacuum pads that help him climb.

There were many other Anolis around. Their favorite position seemed to be on a tree trunk, head downward and well out in a graceful line (Fig. 55). I caught two more and tethered them to my window screen by a bit of dental floss tied 
loosely around the body just in front of the hind legs.

My first Anolis had a dull brown back, faintly patterned, but I found that they were not always the same color. Sometimes they might be brown, or a dull gray, or a light green, and often they would mix colors, with a brown stripe down the spine while the rest of the body was green.

Many people believe that these lizards which change color are always the color of whatever they are standing on. This is not true. One of my lizards was a light grayish green when I decided to place him on a little plant of the same color. He immediately turned to a rich brown, but even then I must give him credit for not being easily seen as he stood, "frozen," head downward. A brown lizard that I found curled around a white nut was well hidden, too. It was much easier to see the nut than the lizard.

Anolis' color seems to be controlled partly by light, partly by heat, and partly by excitement. Whenever he is excited he puffs out bright yellow skin under his throat.

Mr. Ditmars, the "snake man" of the New York Zoölogical Gardens, tells of watching two dull brown male Anolis lizards as they met each other. Both extended their yellow throat fans and approached each other with dancing steps, nodding their heads. As they came closer both changed to an ashen gray. Then they charged 


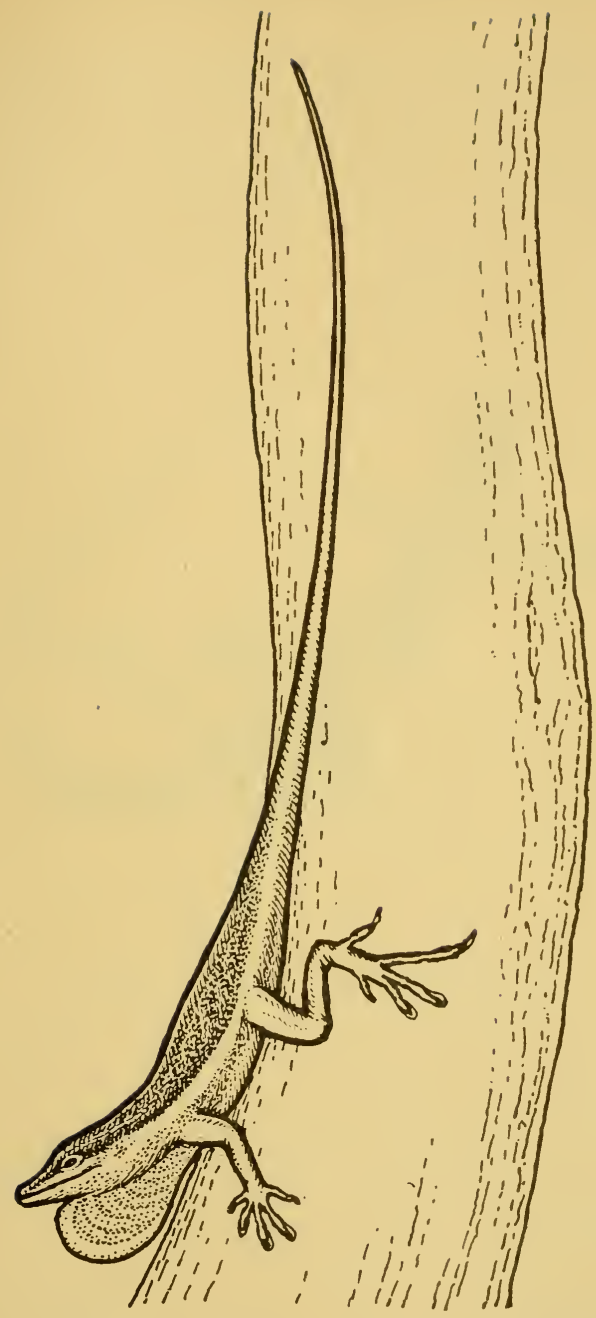

FIG. 55. Anolis, the hopping lizard 
and fought. The lizard that lost the battle scampered off turning to a dull yellow, while the victor strutted away bright green. When the excitement was over and he had settled down to

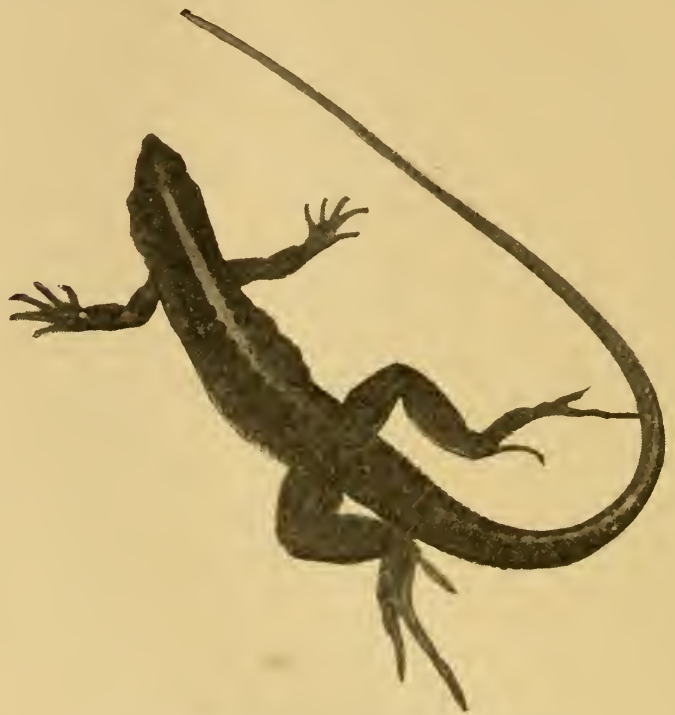

Fig. 56. The brown ground lizard

catch flies once more, he turned to his everyday dull brown.

There is another lizard trick as good or better for protection than the Anolis' changing color or playing dead. I tried to catch a lizard, but my hand closed only on its tail. For an instant the whole lizard was there. Then a squirm and a twist and the lizard ran away, leaving his tail in 
my hand. It is easy for any lizard to break off his tail and then grow a new one and it is one of his best ways of escaping from enemies.

One day I set fat little Cholo to catching any lizards he could find on the island. He came back in half an hour with two lizard tails.

"Why, Cholo," I said, "those are only tails." "Yes, Boss Doctor, this one, she's a tail, but this one, he's a lizard. I saw him jump!"

I knew what had happened. Cholo had struck the lizard, and the lizard had immediately made off, dropping its tail, which wriggled like a snake. While Cholo was gathering up the lively tail its owner had got safely away.

When the tail is brightly colored the trick is still better. One of the common island lizards had a brown back striped with rich yellow (Fig. 56), but it boasted a tail of robin's-egg blue. The body of the lizard was much the color of the dead leaves over which he scampered, so that an inexperienced person or a young animal would notice much sooner the gay active tail left behind than the dark animal slipping away.

Another's white-tipped tail trailed after a brown head and a bluish-coated body. When he snapped off his conspicuous tail, my hand reached for it before I thought and I nearly lost the lizard.

Some lizards run away from danger with the tail held high, offering what seems to be a very 
convenient handle to pick up the whole animal. If the tail is touched, the lizard, of course, snaps it off and leaves it wriggling on the ground. I wonder how many snakes and birds have had only lizard tails for their dinners when they had thought they were about to have whole lizards!

Down close to the water's edge lived some larger lizards with long hind legs and tail. When disturbed they went running out over the surface of the water in the most startling manner. They ran with bodies erect, on their hind legs, spreading the long toes of their hind feet to support them on the water and balancing easily with their long tails. I suppose they could swim if they should chance to fall under the water, but all those that I saw skipped as easily over the surface of the inlet as if it were dry shore. They lived on land too, but always near water.

They look, as they run around, very much as did their relatives, the old dinosaurs (Fig. 57), in

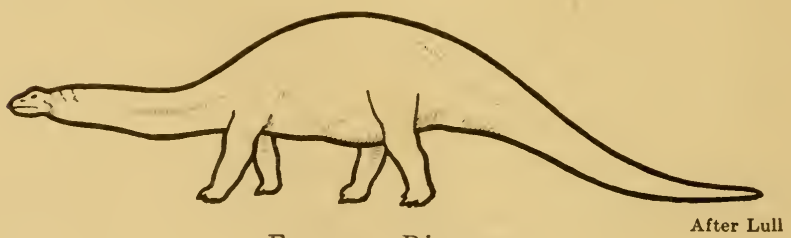

Fig. 57. Dinosaur

the great days of the reptiles, except that one must remember that not even a baby dinosaur would be so small. 
These lizards, called basilisks, grow sometimes to be three feet long. The largest ones that I saw were only two feet long, and most of them were

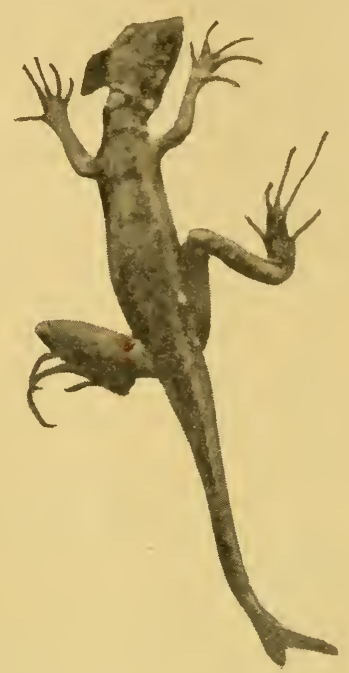

FIG. 58. The basilisk

not half so big (Fig. $5^{8}$ ). I suspect that a beautiful white-and-black hawk that perched near by ate many of them. Like many dinosaurs, the basilisks wear on their heads a handsome crest. The older male lizards add to this a crest running down the spine and another on the tail. A lizard that has parted with his crested tail does not get a ruff on his new tail when it grows.

Unlike Anolis, the basilisk will bite viciously, but since I let them bite a stick or the heavy 
sole of my shoe in place of the finger that they might have preferred, I cannot tell just how painful their bite is.

One late afternoon I was attracted to the door of the shack by the creaking of branches in a near-by tree. Forty feet above the ground, crawling out over the slender branches, was the big lizard called iguana. This iguana was 'a heavy-bodied fellow, five feet long. He climbed awkwardly and the branches swayed alarmingly under his weight. While he was moving about he could very easily be seen, but as soon as he had settled himself along a limb not as thick as his own body he was very hard to see, although

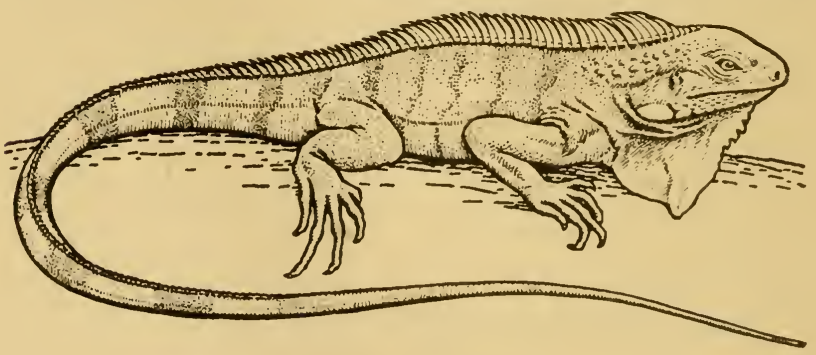

FIG. 59. Iguana

I knew perfectly well where he was and there were not many leaves in the way.

His upper parts were a dark greenish hue, and his flanks were yellow. Both colors fitted well enough the color scheme of the tree, and the pinkish ruff of spines running down the middle of his back looked like the irregular knotty bark 
(Fig. 59). He seemed no more suited to tree life than an alligator would have been, but he was probably as safe there as such a juicy morsel would have been anywhere.

Not only the large forest animals, but the Panama natives prize the iguanas highly for food. Two that John English shot furnished meat for Frijoles over Sunday. My men were willing to bring me plenty of iguana heads for my collection, but they asked permission to keep the bodies to eat. I was warned not to eat chop suey in the Panamanian cafés, because it was sure to be made of iguana meat instead of chicken. Personally I could see no objection to eating meat that looks and tastes like chicken, simply because it came from a lizard instead of a bird. The iguanas' taste in food is quite as clean as a chicken's. They eat leaves and fruit, and probably add to this eggs, young birds, and other small animals as they can catch them.

I saw several iguanas in the branches of shade trees in Ancon, and even a young one, two feet long, running across the asphalt-paved street dodging automobiles. One of my Ancon neighbors complained of an iguana that landed with a thud on his roof every night just as everything was quiet and restful within. They may be seen alive, with their feet tied together, waiting a purchaser in the markets, and they are sometimes shipped to New York alive. 
These are only a few of the many kinds of lizards I saw running about. If I lived in the tropics, I think I should find them as varied and as interesting as the birds we study in the north. Those like Anolis are much pleasanter to handle than frogs or toads, because their skin is dry and warm.

Our southern chameleon, with which you may have played, is a relative of Anolis, and so are the lizards of the southwestern United States. Next time you see one of these remind yourself that millions of years ago, when the coal you burn in your furnace was being made, lizards like these slid through the jungle forests just as they do today. 


\section{STRANGE BIRDS}

I believe more Americans are interested in birds than in any other wild creatures. On the boat that took us down from New Orleans to Panama, people asked me where they could find a guide to tropical birds, like the little handbooks we tuck away in our pockets when we go out to look for birds here. I was sorry to have to tell them that there were no convenient little books with colored pictures to take out birding in the jungle. I should have liked such a guide myself.

Some of the men I knew at Ancon had studied birds, but they always wanted to see a specimen before they were sure of its name. This meant that I should usually have to kill a jungle bird to learn its name, and it is no fun for me to kill a bird. I shot only two birds while I was on Barro Colorado. One was a motmot, which trims his tail feathers in an odd way, and the other was a tiny black-and-red manakin, over which my little daughter grieved so sincerely that I regretted my curiosity about it.

The negroes who were with me on the island were not much help with the birds. They always had names for any that they saw, but I soon found out that the same name might be given to entirely different birds, or that one bird might 
have as many different names as the Prince of Wales.

But there were birds everywhere, and after a while, with many questions, I found out the names of those I saw oftenest. Nearly all of them were strange to me. I was on the Isthmus at the time when summer birds have left the northern United States, but while some of these migrate even farther into South America, I myself saw few that could have come to Panama from the United States. Most Panama birds seemed to be stay-at-homes instead of tourists.

The largest birds and those we saw oftenest were the great black vultures, with featherless, skinny heads, which floated and swung all day long over the city of Panama. When we were in Ancon we lived high on Ancon Hill, with a wide view over the plain where Morgan the pirate fought to take the city many years before. Now a great stretch of the plain is kept cleared for an aviation field, and from above we could watch the airplanes landing or taking off for a flight. The airplanes roared away below us, almost as far as we could see them, but the vultures were on our own level or above us, floating silently on wide quiet wings.

When we went down to the water front of the city, we saw them at closer range (Fig. 60). When the tide went out and left acres of mud uncovered in the harbor, the big birds came down 
on the shore and the mud flats and fought over decayed food stranded there, thrown out from the seaside market and from the boats that brought in fruit to the market.

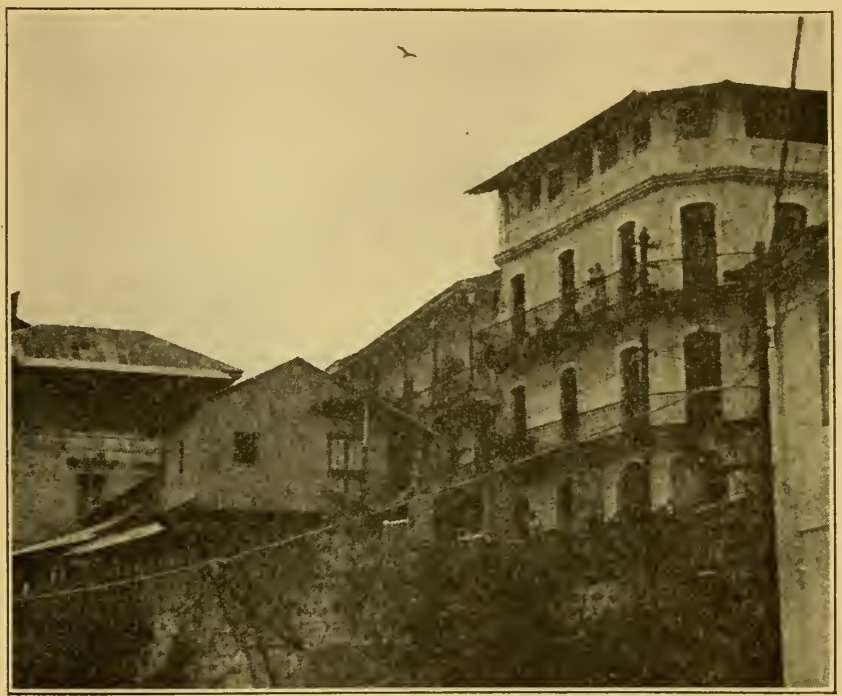

FIG. 60. Vulture hanging over the waterfroni

Down in the bay, well out from shore, were brown pelicans, with queer leathery pouches under their bills to make room for a large catch of fish. These might be seen flying-overhead in the $V$-shaped formation that wild geese use. They dived from the air after fish, beak and breast together, with an awkward, resounding splash that reminded us comically of a small boy learning 


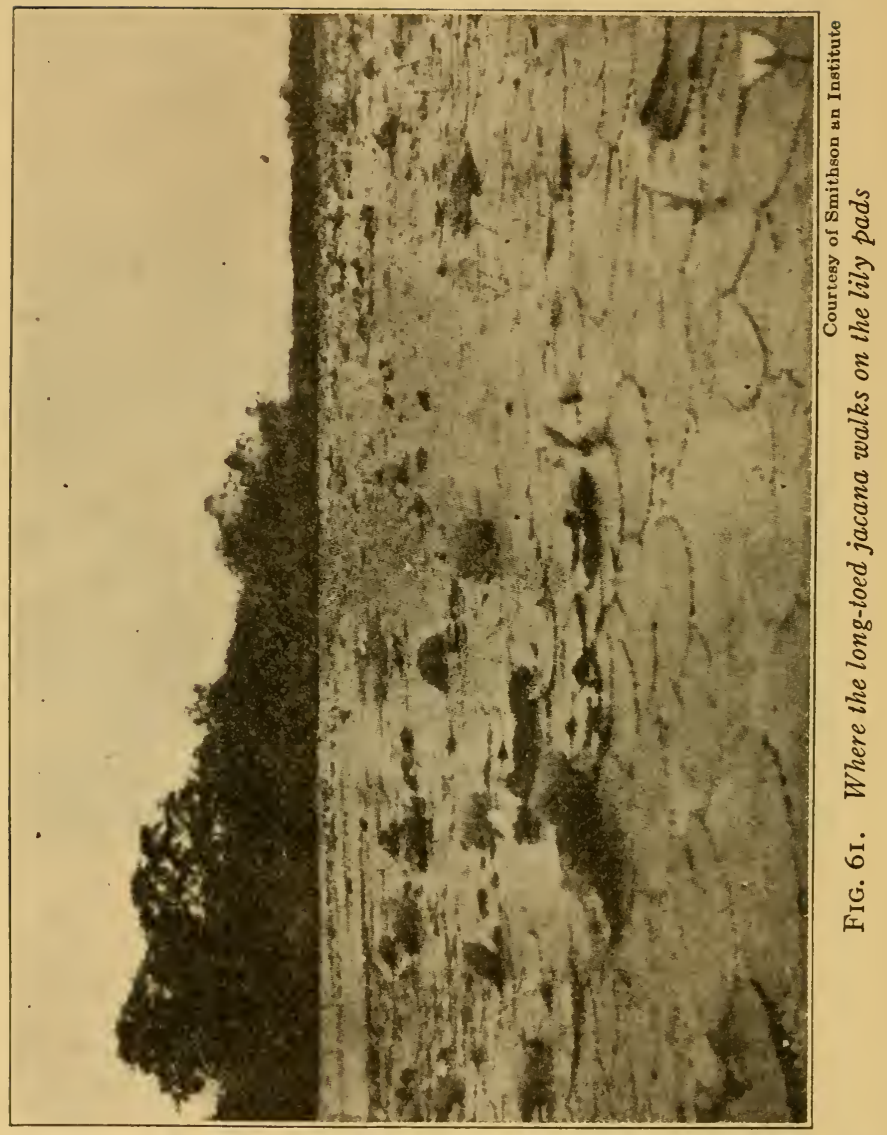


to swim. These pelicans are the same kind that are found along the California coast.

Long-tailed grackles flew about in flocks or singly, much as our blackbirds do in the United States. They seemed to thrive on city life and they were as impertinent as English sparrows. I remember one sleek black fellow that sauntered up and down the platform of the Balboa station as if he were himself a passenger for the early morning train, and squawked grackle talk to the small crowd waiting there. From the train windows we saw them along the cleared and fenced pasture lands. They ranged themselves on bushes and sat there to watch the train go by, looking like shiny ornaments on some new kind of Christmas tree.

We kept a lookout from the train over the lily pads that grow in the quiet bays of Gatun Lake (Fig. 6I), and usually we were rewarded by a sight of jacanas. Jacanas are long-toed water birds which run daintily around over the lily pads, scarcely wetting their feet at all. The bird itself is heavier than a robin, but its long legs end in slender-toed feet with a spread of six inches. The lily pads are small, but the wide feet spread the jacana's weight as a snowshoe does a man's on soft snow.

The jacanas were more interesting than the hawks flying over the Canal or back up in the valleys. The hawks looked much like our own 
marsh hawks, and were recognized by a telltale white spot on the rump.

When we were out on Gatun Lake in our cayucas we often saw long low lines of cormorants flying heavily a few feet above the water. The natives call them "fish ducks." If we were fortunate we might sight out in the deeper part of the lake a floating field of black specks, covering thickly a space half as large as a city block. As we came closer we could see that each black object was the head of a cormorant, whose entire body floated well below the surface of the water. As our boat came near, the cormorants began to struggle heavily from under the water, like tired swimmers. They took to the air until we were past and then as quickly as possible they sank into the lake again, with only their watchful black heads turning above water in our direction.

Sometimes a red-bellied woodpecker flew out from one of the dead snags as we neared shore, and we were likely to see kingfishers of all sizes. Some were about as big as a chipping sparrow and others were larger than I have ever seen in the north. A white hawk, black-barred on wings and tail, spent a great deal of time perched in a water-killed tree close to shore where he could swoop down for the basilisk lizards that ran out over the surface of the water.

We seldom saw vultures over Gatun Lake or Barro Colorado, although they lived in such 
numbers only twenty-five miles away. Their absence shows how very clean the lake is kept. When the dynamiting crew of the Canal came out to the island inlet and blew up old trees and stumps so as to make a safe passageway for motor boats, many fish were killed. Presently the dead fish rose and floated on the surface of the water and the vultures gathered in at once to feed on them. How they knew that any dead animal was there is a mystery to me. I could not yet tell that the fish had begun to smell bad, and the vulture's sense of smell is poorer than a man's.

In most Central American cities, where the streets are not kept as clean as in Panama, the vultures are very useful birds and are held in great respect for their services in cleaning up garbage that would decay, bring flies, and thus cause illness.

If we came down the inlet quietly we sometimes saw a little blue heron standing in the shallow water. The young birds were white. Once we saw three white ones, nearly as large as their blue mother, standing together. These tall pale birds were a sharp contrast to the dark green of the jungle shore.

I have seen a little green heron, the Louisiana heron, and the great blue heron along the shore. Perhaps these had migrated from the north, but it may be that they only looked and behaved like 
northern birds of the same sort. The great blue heron, standing patiently on his stiltlike wading legs, his stout, stabbing beak poised four feet above his wide toes, is a sight to remember whether he is seen beside the Panama Canal or on the weedy edge of the Wabash River.

When we went up the hill back of the camp I sometimes caught a feeling of being at home as a long "whir-r" announced the rising of a partridge-like bird from the forest floor at my feet. This was the tinamou, called by the natives "paradise bird," for what reason I do not know. It is not the brilliant bird of paradise whose feathers women used to wear on their hats, but a dull-colored bird, whose plumage conceals it well among the dead leaves where it lives and whose flesh is very good to eat.

Of evenings I was pleased to have my camp visited by a relative of the whippoorwill. Sometimes he is called a goat sucker on account of his large mouth, though there is no reason whatever to think that any goat ever attracted his attention. The wide mouth strains insects from the air like a net as the bird flies along. Sometimes he is named poor-me-one because of his mournful wail.

He used to come out hunting insects just as I was arranging my headlight to see what I could see in the darkening forest. This headlight was a hot and heavy but useful acetylene lamp that I wore on the front of my hatband. It gave a 
brilliant light that not only helped me to find my way up and down hills, over rocks and roots, and along trails, but also picked up unexpected sights around me. It was when I wore this that the ground was jeweled with reflections of the light from many spiders' eyes.

The poor-me-one flew noiselessly into the clearing and set himself down very low and flat on the ground. In the fast-falling tropical twilight I seldom saw him until one of his eyes caught and reflected the light from my lamp. The spiders' eyes were like diamonds, but the eye of the poor-me-one shone red like the most brilliant ruby. As I moved toward him, he would fly a few feet and come to earth again. Once he flew directly toward me with both large eyes aflame.

Orioles are found on the Isthmus, but they have a much more common relative, called the hangbird, which seems to prefer to build his nest in company with other hangbirds. On Barro Colorado I found a cluster of nests in the lower branches of a high tree (Fig. 62). These were neatly woven of grass, and they hung two or three feet below the branches to which they were fastened. In this tree there were half a dozen nests, but I have heard of trees from which hung fifty nests. The hangbird's body is black and brown and his tail a bright yellow, so that he reminds one of the oriole. 


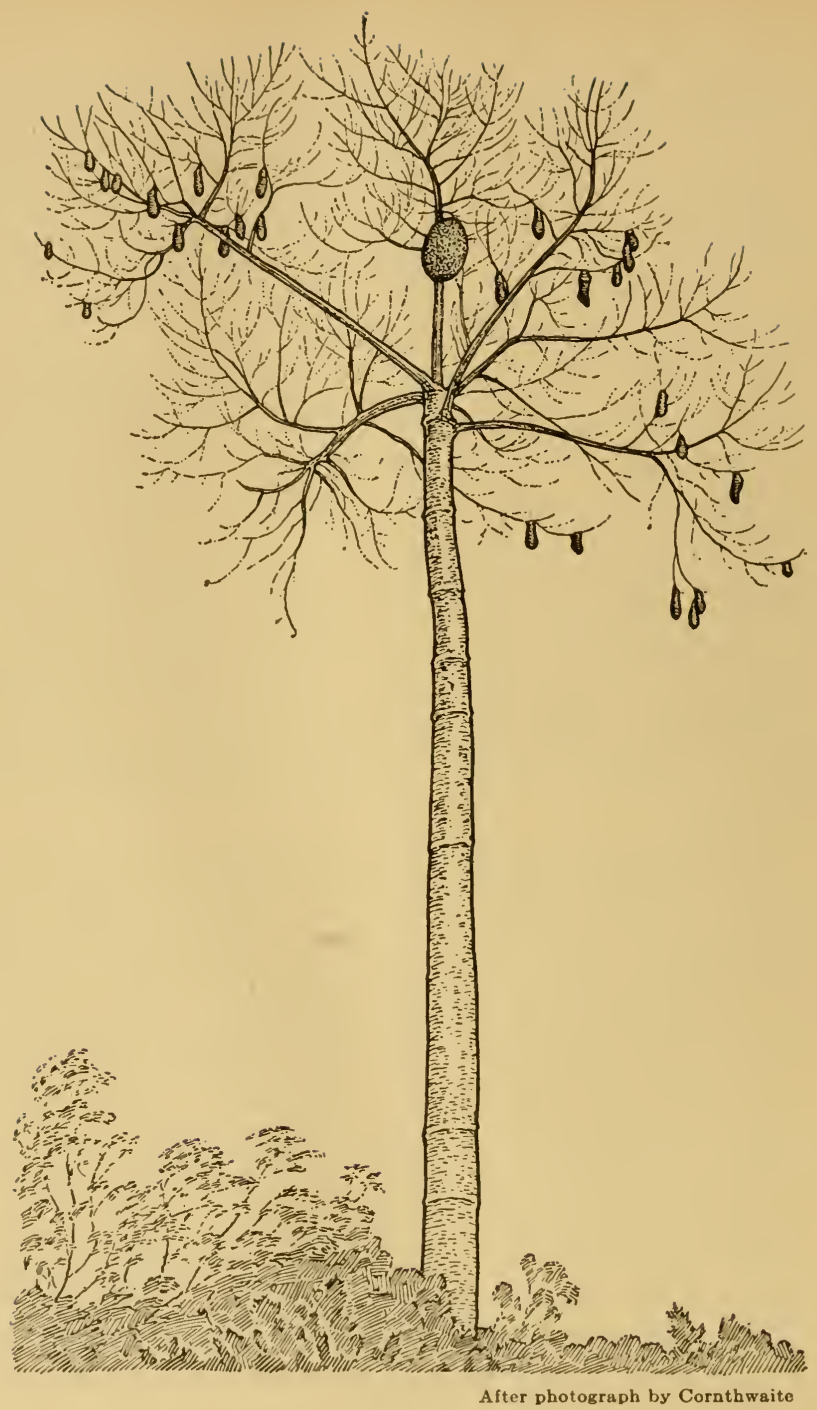

Fig. 62. Hangbird colony and termite nest on a sentinel tree 
The gaudy macaw (Fig. 63) and the brilliant green parrots are like nothing that lives in northern forests. I seldom saw the parrots that I heard shrieking overhead. Their green feathers

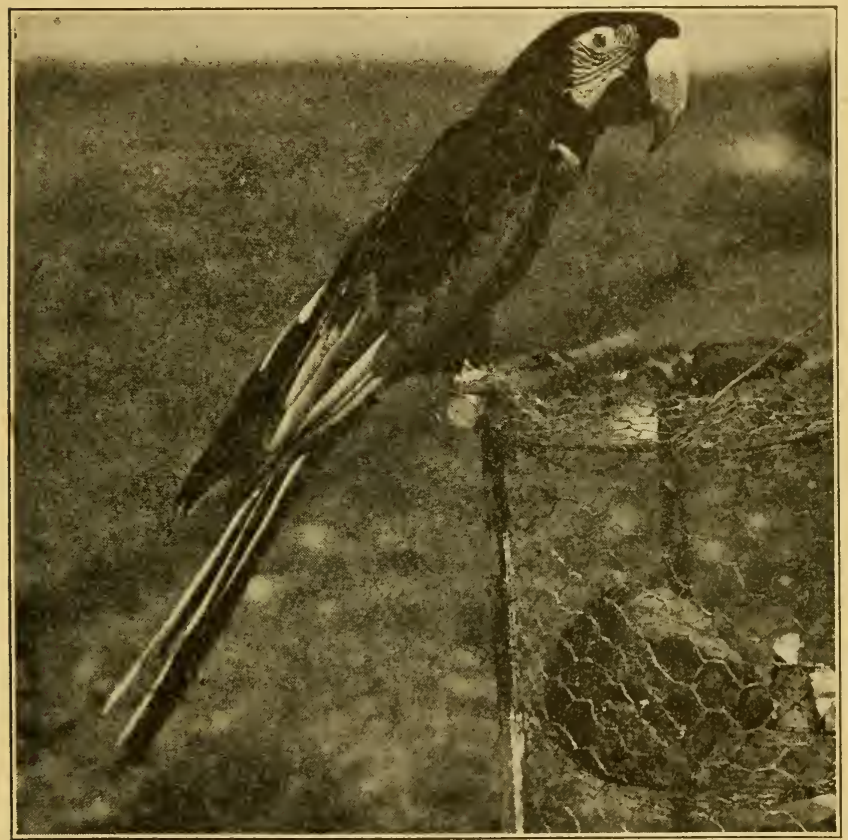

Fig. 63. A gaudy macaw

are too much like the leaves among which they perch. Thomas Belt, who studied animals in the rainy tropics a good many years ago, tells of seeing a single green parrot sitting in a tuft of green leaves. When he shot at the parrot the whole 
tuft fell, and he found to his great astonishment that the leaves were green parrots, too. He had been able to recognize one of them because it happened to move.

The natives capture half-grown birds to sell. Even so young they are good fighters. John English made a parting gift to my small daughter of a newly captured young parrot. We are all very fond of Lorita, but we take pains not to come too close to her stout beak. The sailor who tried to make friends with her on the New York boat, the janitor who "wanted to see if she would peck" - and found out - not to mention numerous hungry neighbor cats, have learned to respect her ability to defend herself. In her native jungle she could probably use her beak to even better advantage.

Lorita (Fig. 64) wears a dash of red on her forehead and shows bands of red on her wings and tail when she spreads them, but when she is sitting on her perch her color is the soft green of young leaves. She prefers to eat seeds, just as she did in the jungle. She does not care for fruits as she used to, and she has developed a fondness for cheese.

She knows a very few words and several whistled tunes and some of the calls the children make. Her voice is loud even when she makes herself ridiculous trying to imitate a canary. Once in a long while, when she is wakened early in the 
morning, she lifts up her voice in the harsh morning call that the flocks shriek together as they fly off overhead, and for an instant we see palms and lianas about us and smell the smoke of the breakfast camp fire.

Morning and evening the parrakeets chattered to one another as they left their high roosts or

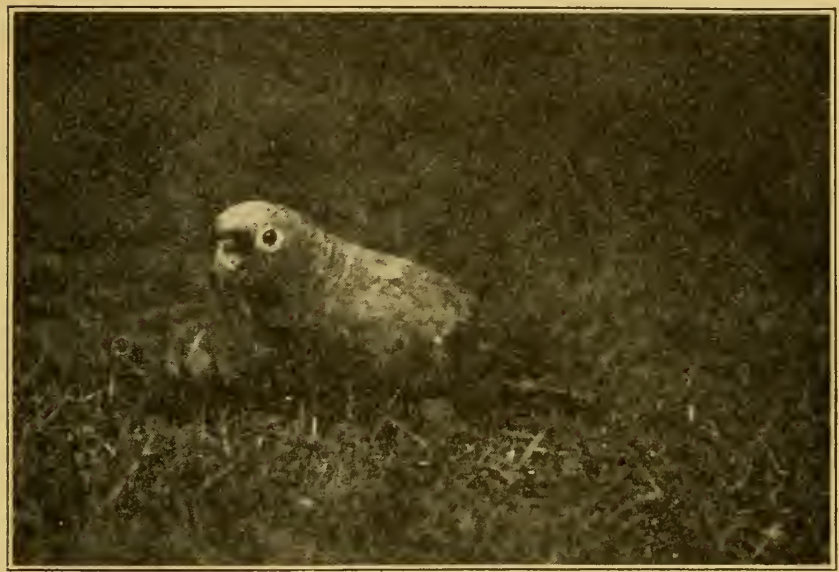

FIG. 64. Lorita

came home again. I never minded their noise, though I have heard it much complained about in other parts of the rainy tropics. They did not disturb me half so much as the lowing of hungry cows of a morning on the farm. I used to watch the parrakeets coming in of an evening to a large sentinel tree near camp. They always flew two by two in small groups. 
The island had the reputation of being a good hunting ground. My black helpers would frequently pause and stand listening in rapt attention and then motion for me to bring my gun and follow them to find "torkeys.". I was told that there were two kinds of "torkeys" in the forest, a "big, big, big red kind" and a "black, black" one. These are not real turkeys, though they do look like them. Their proper name is curassow. Later I found that the red curassows are hens. The gobblers, which are black and usually found on the ground, are as large as small turkey gobblers. Both the gobblers and the hens have beautiful curled crests on their heads.

Usually our "torkey"-stalking expeditions were failures. The birds were shy and easily frightened by the rustling of dry leaves under our feet. Three of the "big red kind" flew over my clearing one quiet day and stopped near by so that I saw their red feet and their dark brown feathers that turn dusky in the shadows.

There is a smaller black relative of the curassows that is not so shy and is also good to eat. This is the "black, black kind" of the natives.

My experience in trying to stalk "torkeys" and attempts to see other animals convinced me that I must have a real trail through the forest. What we had called trails were only blazed paths where almost no clearing had been done. What I 


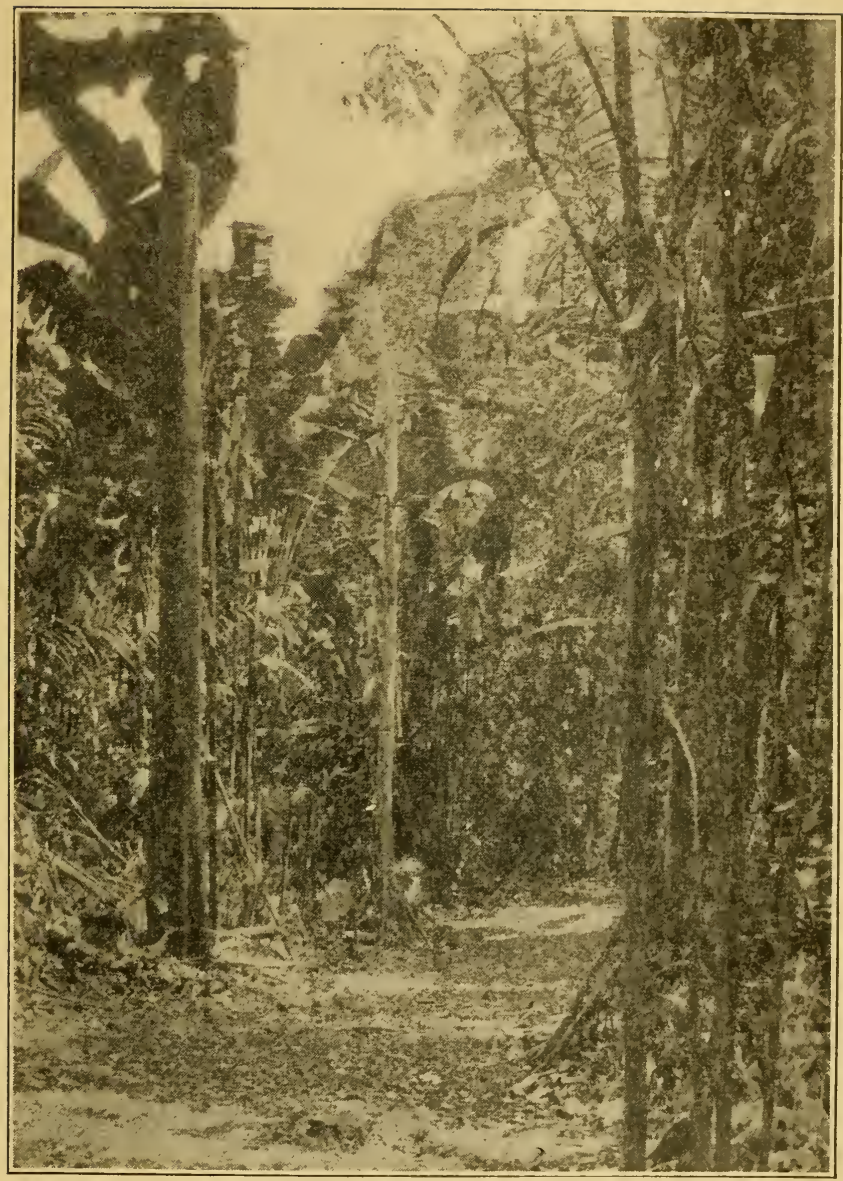

FIG. 65. The machete-cut trail 
needed was a wide passage cleared of underbrush, with all the dry leaves removed. Fortunately Necto liked this kind of work. It seemed to him much less silly than running around looking for useless animals. Under his direction and mainly by his work, a fine trail twelve feet wide, three times as broad as the old Spanish paved roads, was hacked out for half a mile, across two ravines and over the slopes between.

The work was done with only two tools. One was the long machete, which I think he must have picked up as soon as he put on his scanty clothes in the morning, so constantly did he carry it. With this knife he cut down bushes and hacked away roots. The other tool was a forked stick he cut with the machete, to help rake away leaves.

Down this cleared passageway through the forest I could walk quietly without watching my step, with eyes intent on animal life (Fig. 65). Even at night I could follow the trail noiselessly. The trail had another advantage. It was not wide enough to open the jungle floor to the sun, but it did present a cleared space that animals were some time in crossing. For at least a moment I could see them in the open, and sometimes they followed the trail a little way as if it were their road, too. Lizards hopped along it, and sometimes I saw a great blue butterfly floating up over the slope. If I were going again into 
an uncut tropical forest, my first care would be to have miles of such trails cut.

Here along this new trail I found the motmot (Fig. 66), a green-and-brown bird about the size

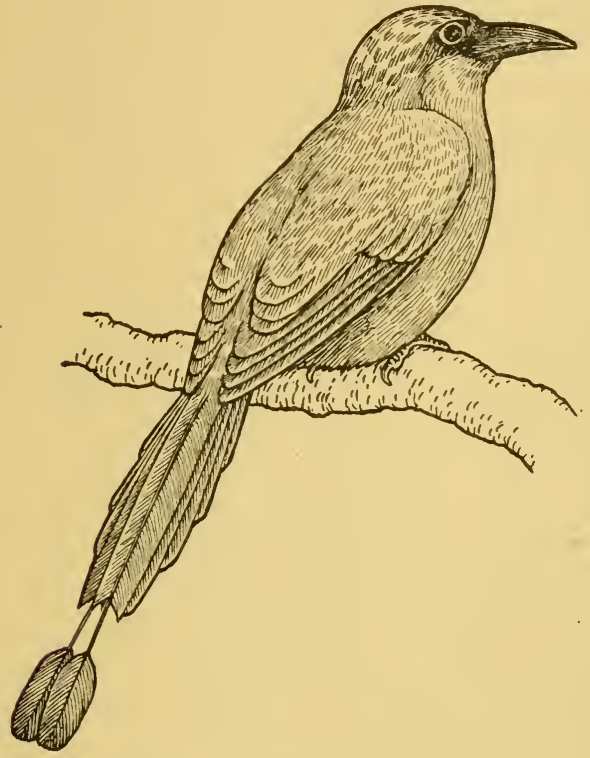

FIG. 66. Motmot

of a blue jay. It had flown silently across the cleared space and was sitting in a jungle bush twenty feet above my head, its green back fading away into the green of the leaves. Suddenly it jerked its tail sideways and the movement attracted my eye. Soon it repeated the gesture as if to call attention to its remarkable tail. The 
two central tail feathers were trimmed part way along the shafts, leaving only a tennis-racket-like end about an inch long on a bare handle the same length. These two feathers grow out three inches longer than the rest of the tail, which, as the picture shows, is otherwise an ordinary tail.

After every molt the motmot carefully trims off the shaft of the new long feathers. It does this even if it is taken from the nest when young and is never allowed to see other birds trimming their tails. The part that is trimmed off is weaker than the rest of the feather. Why do they do it? No one knows. Perhaps for the same reason that makes men shave their beards and girls bob their hair.

Here, too, I found the red-headed and the yellow-headed manakins. These are tiny blackbodied birds whose color pattern is so broken that they look like patches of sunlight in the bushes and are not so easily seen as one would imagine from their gay heads. A yellow-headed manakin had built a nest on the fern-topped stump in Gatun Lake pictured in the second chapter (page 33). She shared the pretty spot with a swarm of stingless bees.

Along the trail I caught my only glimpse of the snow-hooded bell bird, whose song, like the dropping of water on tin, I had heard when I first came to the island. His dull-colored mate and young were more often seen. 
The tropical humming birds made themselves at home along the trail as they did everywhere in the forest. At home I had known the little ruby-throated humming bird that haunts honeysuckle vines. Here they were almost as large as sparrows and nearly as inquisitive.

One evening near sunset, while I was sitting by the little creek, a large green-throated humming bird came up, apparently attracted by my new tan cloth hat. He came gradually closer, pausing at different levels and holding his place in the air by moving his wings so fast they could not be seen. If startled he darted several feet straight up into the air and held himself poised there. At last he came within easy arm's reach, with his long sharp bill pointed directly toward my eyes, so that I guessed it must be the gleam of my eyeglasses that fascinated him. After a careful examination he flew off, having decided, no doubt, that there was no food around me.

Again, one of these graceful, rapidly moving little fellows flew under my arm as I was writing in my notebook in the forest. They seem to be quite fearless, perhaps because they can dart away so rapidly from the attacks of bigger creatures.

Mr. Beebe, who has written about the birds and animals of the South American rainy tropics, tells of finding the humming birds sleeping on bare vines or shrubs with their heads tucked under 
their small wings just as bigger birds hold theirs.

Part of their food is probably honey from flowers, as we have always been taught, but when we look at their tongues we find them forked at

\section{FIG. 67. Hummingbird's pincer tongue}

hfter Belt

the end so as to make a very good pair of pincers (Fig. 67) for picking up the smallest bugs. Thomas Belt, the English naturalist, who first found out about their tongues, thought that when they visit flowers they are picking off little insects. They carry pollen from one flower to another, just as our bumblebees do in clover, and so help seeds to form.

The most distinctly tropical birds were the huge-billed toucans, which the natives call by a Spanish name that means "beak of iron." The commonest toucan was a black bird about eighteen inches long from tip of tail to tip of beak. About one-fourth of his length was his round olive-green bill, which was painted lengthwise with wavy red and yellow lines. Under his chin he wore a circular, bright yellow bib. Seen either in a picture or in the forest, he looks as if he had tied on a false beak to go to a masquerade (Fig. 68).

I saw these birds flying past my spiked tree with somewhat labored flight, head held down as if by weight of the bill. Considering its size, the 
bill is lightly constructed, although it is strong. Its hollow shell holds, with much room to spare, a long slender tongue.

There is a great difference of opinion as to the usefulness of his tremendous bill to the toucan. It can drive a slashing blow and perhaps it is a good weapon to defend the toucan's nest in a hole in a tree from monkeys and iguanas looking for young birds and bird eggs. Such a bill could also cut out huge bites from the tropical fruits on which the toucan chiefly feeds, and it is said to be used to excellent advantage for reaching into cracks and corners after bugs when the bird has a taste for animal food. Perhaps it is safest

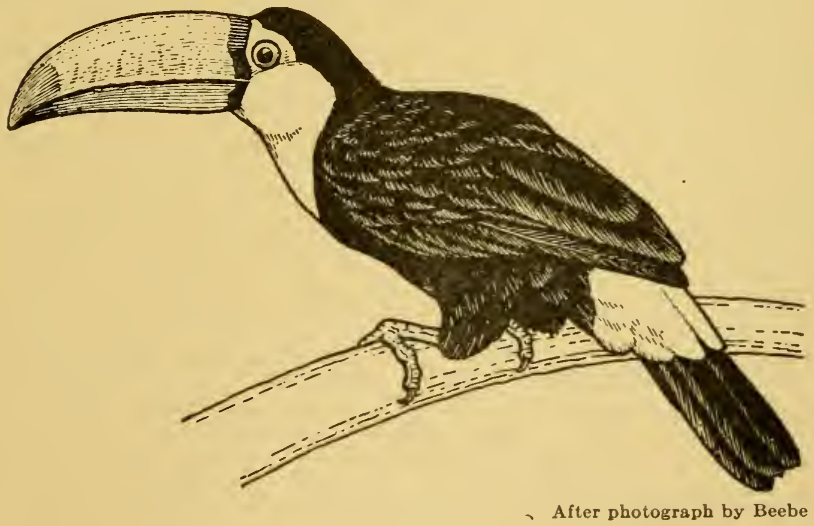

FIg. 68. Toucan

to say that the toucan's beak, like some people's noses, just grew that way, and both have nothing to do but make the best of it. 
At night the toucan becomes an even more comical sight. He sleeps outside his nest on a limb, folding himself up like a jackknife. First he twists his neck till the great beak lies down his back like the ridgepole of a roof. Then he humps up his wings to make supporting side walls along the beak. And last, his spread tail is bent forward roof-like over wings and beak. 


\section{FURRY ANIMALS}

Barro Colorado Island is a wonderfully fine zoölogical garden. Safely penned in by Gatun Lake, it keeps examples of most of the animals to be found anywhere on the Isthmus of Panama, all going about their business without the trouble of any keepers to feed and care for them. It must be said, however, that many of the animals, although they are none the less interesting, are so small that no zoo would bother to keep them. In a big museum you might find a stuffed lizard or perhaps a model of an ant's nest, but when you go to the zoo to see live animals you expect to see for the most part some of the big furry animals that we call mammals.

For myself, I like best to study the insects, but when I went to the jungle I wanted to see all the other animals in the Barro Colorado zoo as well. As it turned out, I saw and heard fewer mammals than any other kind of animals, but my luck was as good as most people's, and it began almost as soon as I came to the island.

On our first day we were so noisy as we cleared a partly overgrown trail and pushed into the underbrush after strange plants that we must have scared away any big animal that might have been close. The next day I started exploring 
with two soft-footed negro guides, and I did my best to follow them noiselessly up the rocks of a dry creek bed.

Suddenly Blanco, who was leading, motioned for me to come up with him very quietly. The banks of the creek were nearly as high as our chins. Feeding on the leaves at the level of our eyes, I saw a great many animals that I thought at first to be small brown, doglike monkeys with long tails. When one looked in my direction his long pointed nose and the gray markings about his eyes told me that he was either a raccoon or a relative of the family. Blanco called them gotosolas. The usual name is coati (Fig. 69).

When a white-and-black hawk flew into a nearby tree, the coatis all scattered. Blanco told me that the reason they were on the ground was because the hawk was hunting them.

The coatis themselves are hunters. Belt tells of seeing packs of them hunting iguanas. Some would climb the tree and chase the heavy iguana so far out on a slender limb that he would fall and be caught by the pack beneath. When one coati went hunting by himself, he had a much poorer chance of iguana for his dinner, since the iguana could drop and climb another tree before the coati could reach the ground and be after him again. But even when he lost one iguana after another, the coati would keep patiently on his search, hoping, perhaps, 
to find a fat iguana so very sound asleep that he would not wake up until he had been caught. If he became too hungry from the chase, the coati could always stop and fill his stomach with leaves and fruit.

The coatis are sociable animals. Sometimes I saw them singly, lying on branches looking down at me, but oftener they were feeding in groups. Some of the small groups might have been families,

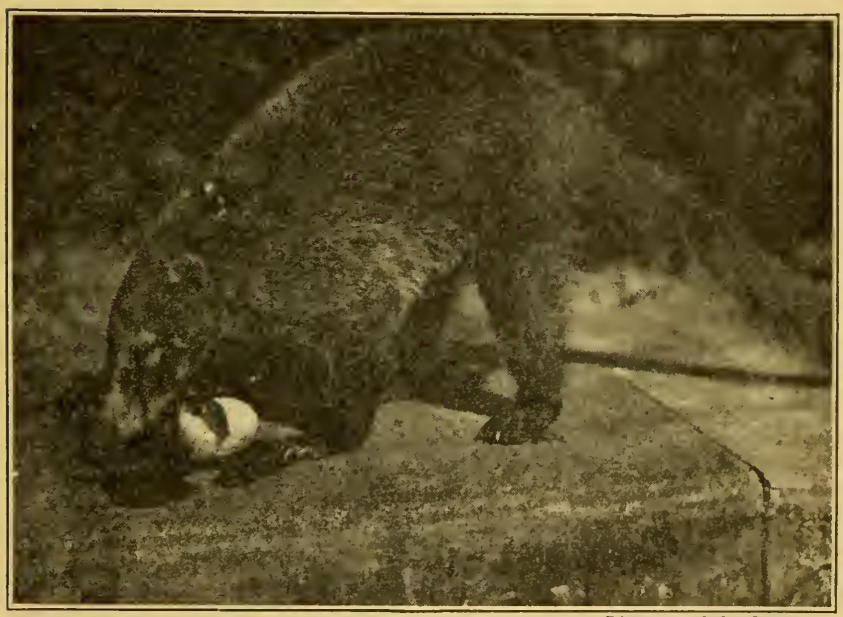

FIG. 69. Coati

Photograph by Richter

but others were much too large to be only one family. They visited my camp at night, wakening and startling me as they scratched among the camp-fire sticks. They fight savagely dogs that hunt them, but when tamed they make clever pets. 
As we went on up the ravine we were much excited to find tapir tracks. Tapirs are big, shy animals, not often seen, though their tracks are fairly common. We saw nothing but the tracks.

Ahead of us came the scolding of a white-faced monkey. We went quietly forward until we saw the trees overhead shaking suspiciously and, looking up through my excellent bird glasses, I found a dark, doglike back and a long tail. Then the animal turned and I found myself apparently looking into the face of a wrinkled old woman with white forehead and black-penciled eyes. She moved and stood up, evidently as much interested in me as I was in her, and I saw her yellowish-white shoulders. Another larger white-faced monkey that might have been her mate came up and jumped deftly in front of her as if he wanted the best view himself. She looked over his shoulder, while he cocked his head first on one side and then on the other. Soon he jumped lightly and gracefully over her so that they were sitting side by side, inspecting me from their balcony. Then they silently disappeared among the branches, leaving me with a strong feeling that I had seen something very human.

These monkeys, called white-throated capuchin monkeys after the hooded Capuchin friars, are the most common of the monkeys about Gatun Lake. They eat more animal than plant food. They are always on the watch for insects, and will 
munch a large bug with as great relish as a boy eating a piece of candy.

Next after parrots, they are the commonest pets sold in the shops of the Canal Zone. It was

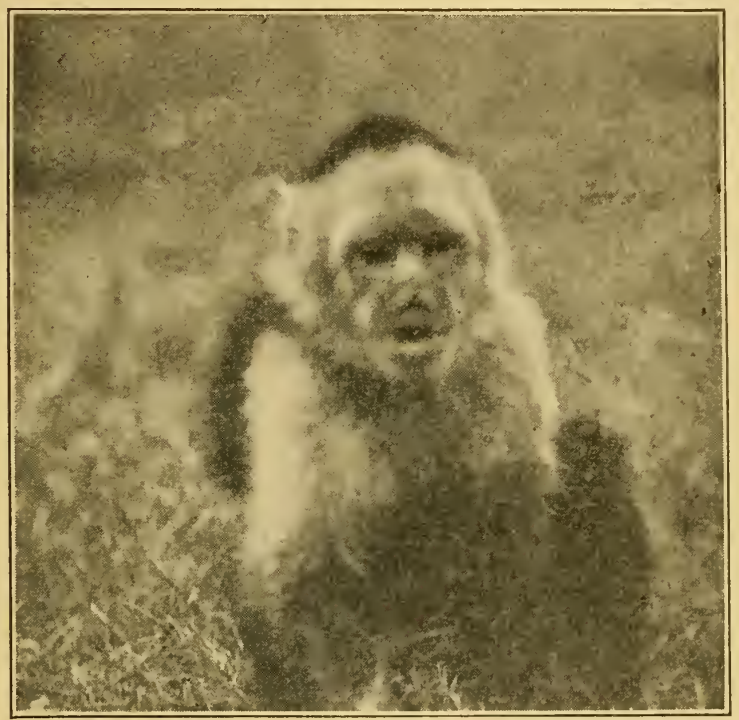

FIG. 70. The common white-faced monkey

at Colon that we took the picture given here (Fig. 70), which would have been very hard to get in the jungle.

Belt tells of one that he keptas a pet. It was fastened to a light chain to keep it out of mischief, but the chain did not prevent it from catching the young ducks it wanted to eat. It would hold a piece of bread in one hand until the little ducks 
were close to it, and then it would seize a duck and kill it with one bite. This is an appetite it learns in the forest, where it eats little birds and nestlings whenever it can take them.

Captain Marty, the Swiss who ran a government launch on Gatun Lake, told me, "I like monkeys better out of doors. , When my Teddy was a baby, I had a monkey. One day I came in and found that the monkey had taken Teddy's bottle away from him and given him a kitchen knife instead. Teddy had the knife in his mouth and the monkey was drinking Teddy's milk."

Farther up the ravine we found more threetoed tapir tracks. These were fully six inches across. Then we saw large cat tracks which Blanco said were "tigre" tracks and I knew must be those of either jaguar or ocelot. There was a muddy pig wallow by the stream and tracks of the wild pig leading away. They looked like those any barnyard hog might have made. As we turned back to camp, the ear-filling bellow of a black howling monkey came across the gathering jungle twilight, but it was too late to look for him.

Under a root we caught a glimpse of an armadillo resting in his coat of mail. When disturbed he came straight toward us and disappeared down his hillside hole. The natives called the armadillo a "ground hog." 
On other days, of late afternoons, I saw armadillos again, rooting about in the leaves of the dark forest floor. Their food is mainly insects, and most of these are ants. They do not seem to see or hear very well and have been known

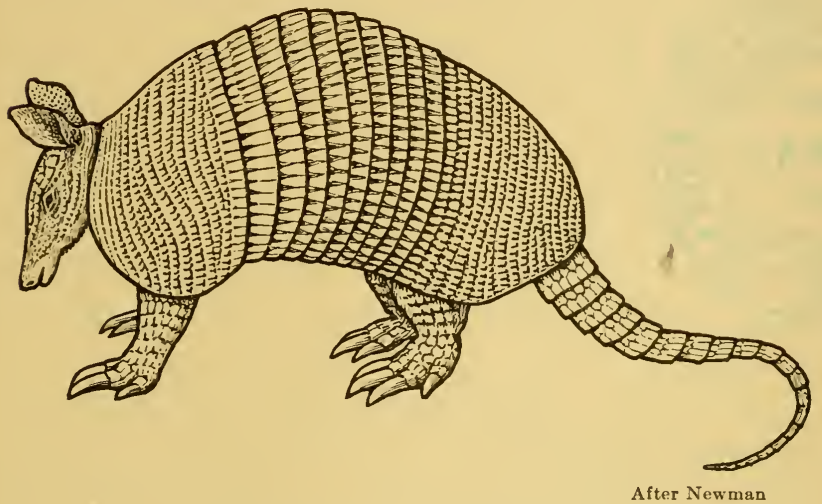

FIG. 7I. Armadillo

to run headlong into tree trunks when disturbed. Probably they rely on their sense of smell for warning of danger.

With their powerful forepaws they dig very rapidly. They usually have holes near their feeding grounds into which they can dodge if frightened, as well as permanent holes, six or seven feet deep, with a den two feet in diameter at the bottom.

The most noticeable thing about the armadillos is their curious bony armor (Fig. 7 I). This undoubtedly helps to protect them when a tiger 
cat gets after them, but a stronger animal, like an ocelot, can bite through the armor. When attacked the armadillos turn over on their backs and strike out powerfully with their claws.

When I was on the island by myself the next week, playing Robinson Crusoe without any Man Friday, I climbed on the second day to a palm thicket at the top of the ridge above my shack, where I had a view down into a ravine on either side. From daybreak on I stayed there, measuring at regular intervals the amount of light that sifted through the palm leaves, and keeping perfectly still between times to see what would come my way.

Before the drowsy quiet of mid-afternoon nothing but mosquitoes, wood ticks, ants, spiders, and beetles had come along, with an occasional humming bird venturing inquisitively close to my face.

About half-past three a hoglike animal twelve inches high, light brown, slab-sided, with cropped ears, and almost tailless, came trotting actively along my ridge. This was my first sight of the wild pig, or peccary, whose wallow I had found along the creek bed the week before. About twenty feet away it saw or smelled me, stopped, grunted, and made off slowly down the ravine, where I could hear others rooting about among the dry leaves. Peccaries are hunted and are considered good eating. 
The peccary was scarcely out of sight when a coati appeared about two rods down the hill nosing into roots of trees. This one was quite alone. He sauntered on toward my camp without knowing I was about.

It was time to make another light-measurement. I was sitting working on a low box when

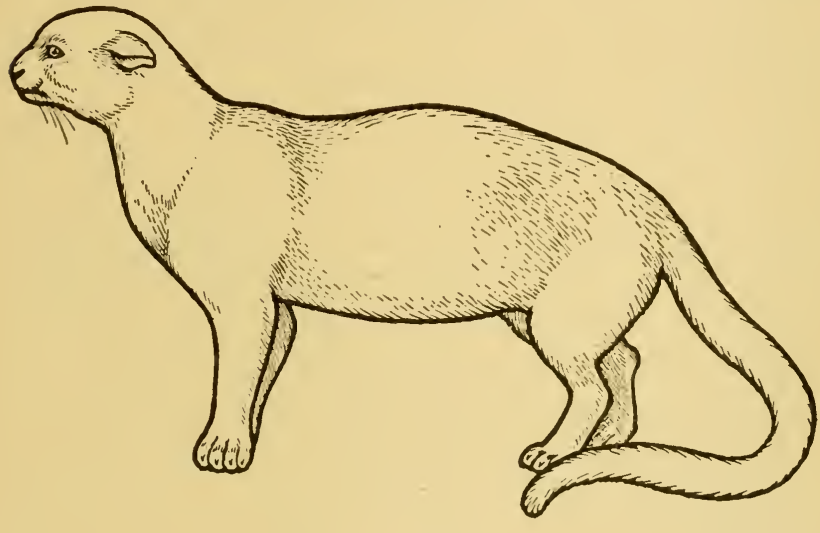

FIG. 72. Yaguarundi

After Alston

out of the corner of one eye I saw something coming up from camp directly behind me. Turning my head as slowly as possible, I found myself looking into the eyes of a coal-black animal like a big cat (Fig. 72). His broad, blunt-nosed head was set on a stout body and his tail was long and fluffy like the coati's.

He came on until he was no more than twelve feet away before he saw me. Then he stopped, 
crouched, and hissed like any startled pussy cat. We looked at each other without moving. My machete was six feet away leaning against a tree. My little revolver, which sometimes fired and sometimes did not, was in the bag at my feet. Suddenly the black cat sprang back twice its distance, hissed again, watching me closely, and then circled around me down the hill and up again to the ridge, as if it were returning to a path I had blocked.

How big was the cat? I cannot be sure, but I think that its furry tail was nearly two feet long and the head and body a little longer. Santiago saw it later and insisted that it was six feet long. The natives to whom I told the story, called it a "chicken cat." The real name is a tongue twister, "yaguarundi," and chicken cat fits well enough its habit of eating big ground birds. I later found chicken-cat tracks around a heap of feathers that was all that was left of a "paradise bird." Santiago was very plainly afraid of it, but I do not believe it would show fight against a man unless it were first attacked. More than one night a big cat prowled around my shack without ever attempting to push through the muslin-curtained doorway behind which I was sleeping.

That afternoon and the evening before there had been a sound in the near-by trees as if some animal were crashing recklessly about, though 
there was not the creaking of branches that the weighty iguana would have made. I found, sitting there, that all the racket had been made by a big, bright, red-tailed squirrel. While I watched him from thirty feet away he hung from the side of a tree, head down, eating a nut which he held in his forepaws.

Moving about before I went down the hill to the shack, I almost ran over a tall, odd animal, that looked as if he had been put together by sticking a rabbit's head on a pig's body. The

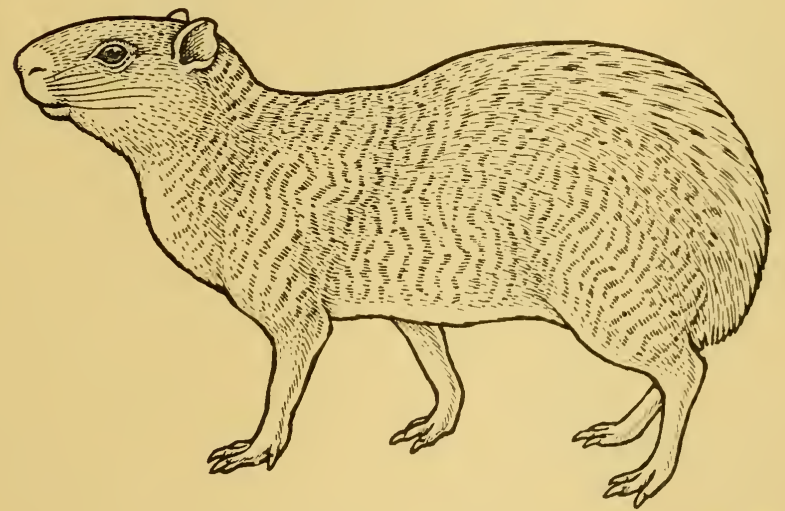

After Alston

FIG. 73. Nequi

natives call these nequis (Fig. 73), and find them good eating. I thought the meat tasted rather like squirrel. This particular nequi seemed to live in a hole near my camp, and we found other nequi holes as we went about the island. The 
nequi is one of the large South American rodents that are found only in the rainy tropics.

Conejos (pronounced kố-nā'hōs) lived in holes too. They are also rodents, and look somewhat like large guinea pigs. Indeed, they are related to guinea pigs, which grow wild in South America. The natives hunt and eat these as we hunt rabbits.

In the late dusk of the evening bats came out and flew about the camp clearing, chasing insects and making a little squeaking noise as they flew. In the daytime we often looked for bats in old hollow tree trunks and in the rolled leaves of the heliconia, which is a plant that reminds one of a huge canna. The only bats we actually captured, however, were found in the longdeserted, dark guardrooms of old Fort San Lorenzo at the mouth of the Chagres River, where they were seldom disturbed by visitors.

This day was a very good beginning, and I looked forward happily to many days of watching large animals. But it was well that I was interested in smaller beasts, too. I worked quietly, walked through the jungle as cautiously as the dead leaf carpet would allow, and paused often to stand still or squat on my heels. I sat for hours at a time astride a big limb ninety feet up my spiked tree, but I never again saw many big animals in my zoo.

The small laboratory was built soon, and, though the workmen went away every night, the 
noise and confusion through the daytime must have driven the more nervous animals as far away as the island would let them go.

We found in our wanderings about the island three different groups of black howling monkeys.

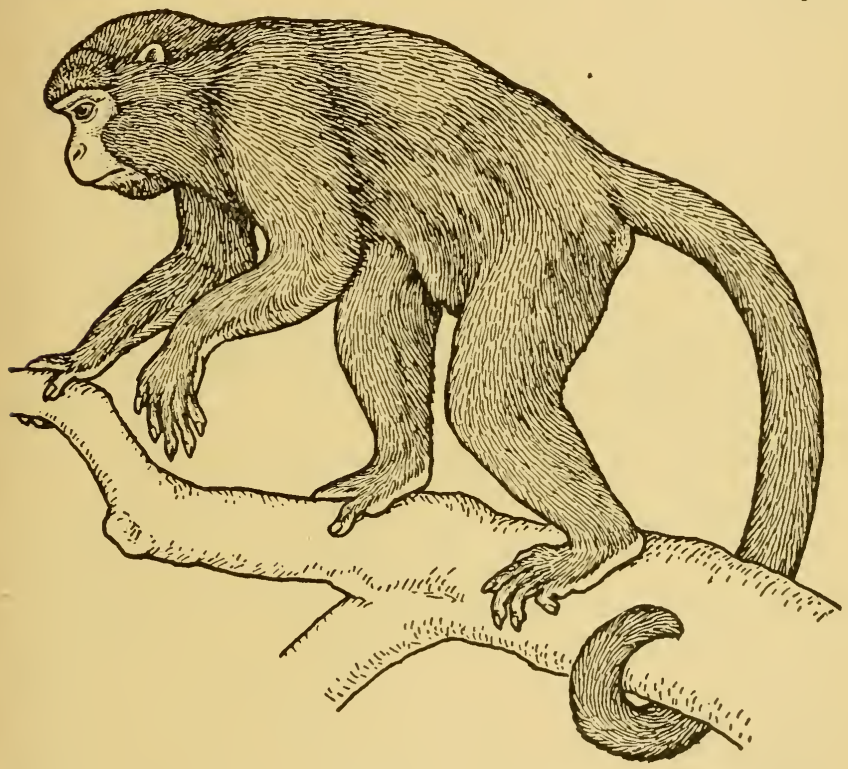

FIG. 74. Black howling monkey

After Alston

A male and four females came through the tree tops one morning to watch Santiago driving spikes up the sand-box tree. Another day, when there were visitors from Boston on the island, we followed the howling of a monkey until we found him with two females in the top of a tall tree, well hung with lianas. 
His excitement and his howling increased as we came closer. He climbed to the top of the tree and tried to drive us off with filth. Then he swung down a stout liana and climbed up again, howling all the way, until the tree seemed full of noise.

The howler families did not appear to move far. I usually heard their bellowing from the same places. They often set up their dismal howls near noon, or when one of the airplanes stationed at the Canal Zone hummed by overhead, or just at the beginning of one of the rare showers of the dry season.

A sleek black howler (Fig. 74) was the pet of a family in Ancon. I saw it come out of the house with its mistress and down the walk to a waiting automobile. The mistress took the driver's seat. The monkey, which had ambled quietly on four feet by her side, swung like a flash up the tree under which the car stood, down a branch, and dropped neatly into his place on the rear seat, from which he peeped out as any other -well-behaved passenger might as the car drove away.

The night monkey, smaller than either the howler or the capuchin, I sometimes found around the camp clearing or down my newly cut trail, but all that I saw of him there was his bright eyes, reflecting the light $\mathrm{I}$ wore at night in my hat band. In the open basement under John English's 
house, where his family, his friends, his chickens, dogs, and pets spent a great deal of the day, I saw one of these monkeys in a cage. Its large owl's eyes and face looked out of place on a body like a cat's. A negro had caught it and was keeping

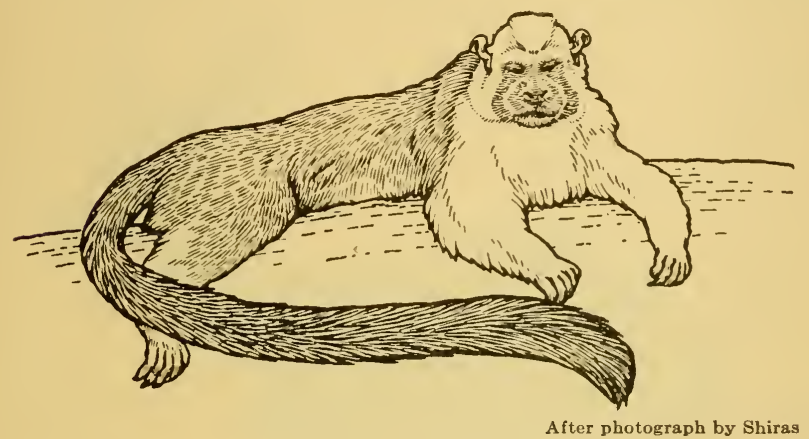

Fig. 75. Marmoset

it there until the United States fleet went through the Canal in April, when he expected to find some battleship crew that would buy it at a handsome price for a mascot.

The tame and handsome little marmosets (Fig. 75) I saw only on the streets of Colon, where they were being peddled to tourists. They are about the size of squirrels and look much like them. One thing that marks them as monkeys is that the first toe on each foot has a thumb nail, instead of the squirrel claws that grow from the other toes. This monkey hand is better at picking up things than the ordinary paw. 
The marmosets are orange-colored, as gay as any jungle bird. In the forest they travel sociably in groups of about half a dozen. They can leap several feet from one tree to another.

We never found any deer, although we saw their tracks on the island and I heard stories of

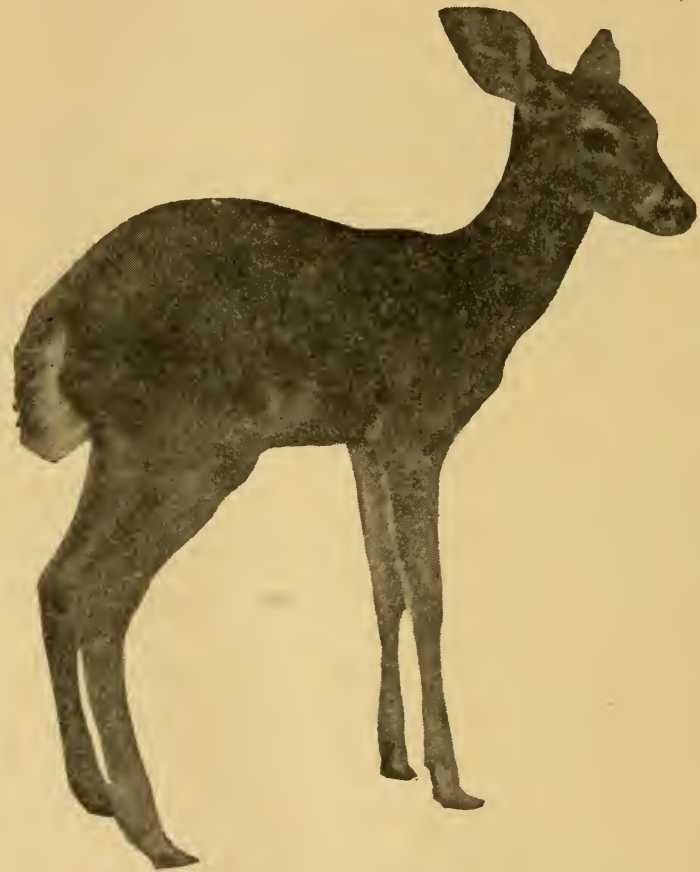

Fig. 76. $A$ fawn

their having been hunted there. My men brought me some venison from a deer they had killed on the mainland. In an animal store in Colon we 
made the acquaintance of a fawn (Fig. 76), probably a different kind of deer, which was so tame that it licked my hand for the salt on it.

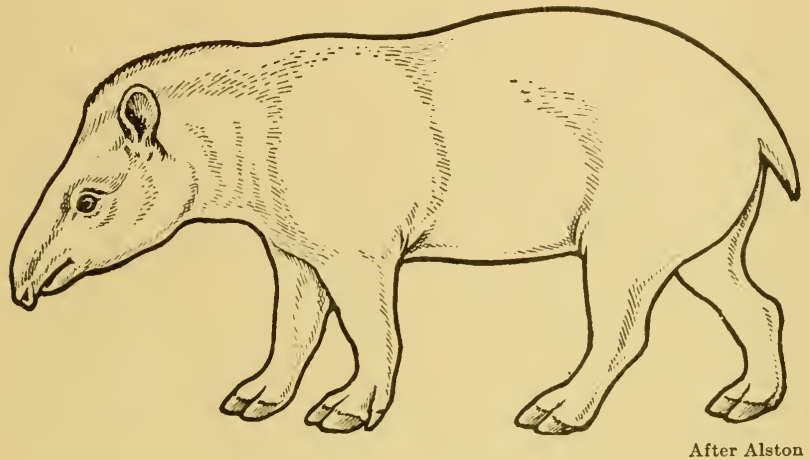

FIG. 77. Tapir

My greatest disappointment was in not finding a tapir. We found tracks on different parts of the island, but never did we see one. The natives were afraid of these big animals, which they called "mountain cows," and I should not be surprised to find they had led me astray once when we thought, from fresh tracks, that one must be near.

The tapirs (Fig. 77) are relatives of horses and rhinoceroses. They are found in Central and South America and across the world on the Malay Peninsula. They are supposed to have lived first in Asia and to have made their way across Siberia into Alaska and down into America, in the days when all the world was much warmer and it was comfortable traveling where now are ice and 
snow. We find their bones still buried in northern Asia and North America, but no tapir lives now outside the tropics.

They like shady forests close to water, where they can bathe when hot and hide when hunted. They grow to be about four feet high and weigh nearly a ton, which is as much as a heavy draft horse weighs. Although they are shy and inoffensive, they can make a truly terrifying noise crashing through the jungle in a bee line of escape. My Canal Zone policeman friend with whom I hunted for them assured me that they went like an express train and that they would certainly knock down a man who stood still in their path. This seems to be the only cause the natives have to fear them, and it must be said that the natives fear most things in the bush, whether real, like tapirs, or imaginary, like pink scorpions.

I was somewhat consoled for my failure to find a tapir by learning that many others before me had looked for them in vain, including Thomas Belt, who did not see one in all his four years in Nicaragua.

Neither did I see a live sloth in his native bush, but I did examine with curiosity and amusement the sloth caught by two Frijoles negroes. Of all the animals that my unfamiliar eyes met in the tropics this is surely the strangest.

His body looks like a dirty, shaggy doormat (Fig. 78). His head and face are those of an 
idiot monkey. The most useful parts of his body are his four stout legs armed with strong claws with which he slings himself like a hammock to the limbs of trees. When he is put down on the

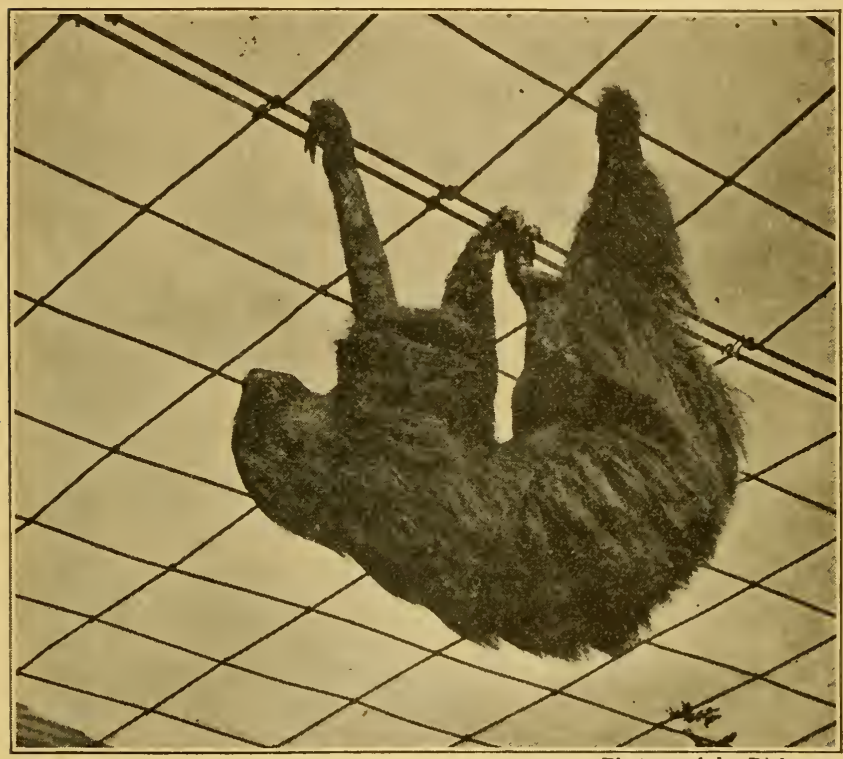

Photograph by Richter

FIG. 78. Sloth

ground these legs become as useless as if the joints had been dislocated. He hooks himself along to the nearest bush by his elbows and knees.

Once hung to a limb like a great wad of dry moss, the sloth stays as still as its name would indicate. Sometimes small green plants, called algae, grow among its hair undisturbed, and then 
it looks even more like a mossback and is hard to see. This one that we saw had a darker pattern on its back, like a dead leaf, which would camouflage it very well from below. The sloth bestirs itself occasionally to eat green leaves, and sometimes it is found asleep, curled up like a bird's nest, in the top of a tall tree.

Although the sloth seems like a collection of misfits, he is suited well enough to the simple life he leads, which would be stupid for a more active animal. He possesses also the valuable quality of being almost impossible to injure fatally by ordinary methods. He does not have to move out of the way of poisonous snakes, for snake bites do not poison him. And for ordinary wounds of any kind he cares as little as the lizard minds losing his tail.

The large animals found on Barro Colorado are of the kinds found all through the American rainy tropics. The northern line of this part of the world is shown on the first map in the book, running up into Mexico. A much greater share of the warm rainy countries is in South America. The Isthmus has served for a land bridge between Central America and South America. The Canal with its constant traffic will cut this bridge apart, though it is too early to tell what effect this will have on the large animals living on either side. We shall have to wait and see if it makes any difference. 


\section{THE CONQUEST OF THE MOSQUITOES}

When the first Spanish soldiers were brought over to the Isthmus to guard the coast from pirates and the pack trains from robbers, forts were built to lodge them safely. Fort San Lorenzo was built at the mouth of the Chagres River to protect shipping, and though the fort was once destroyed by the pirate Morgan it was rebuilt again even more strongly, and a great deal of the old masonry may still be seen, overgrown with jungle.

These early Spaniards, like everyone else of that time, thought that there was something dangerous in night air. As we have said, one of the diseases from which they suffered most on the isthmus was called "mal-aria," which means "bad air." Yellow fever was a new disease to Europeans, who seem to have caught it first from Mexican Indians, but they soon decided that it was spread by night air, too. They believed that they could keep well by shutting out all the outside air at night.

The only openings in the big squadrooms where the soldiers slept at San Lorenzo were the doors like that in Figure 79. When the door was shut tightly at night, the room must have been very hot and stuffy indeed. 


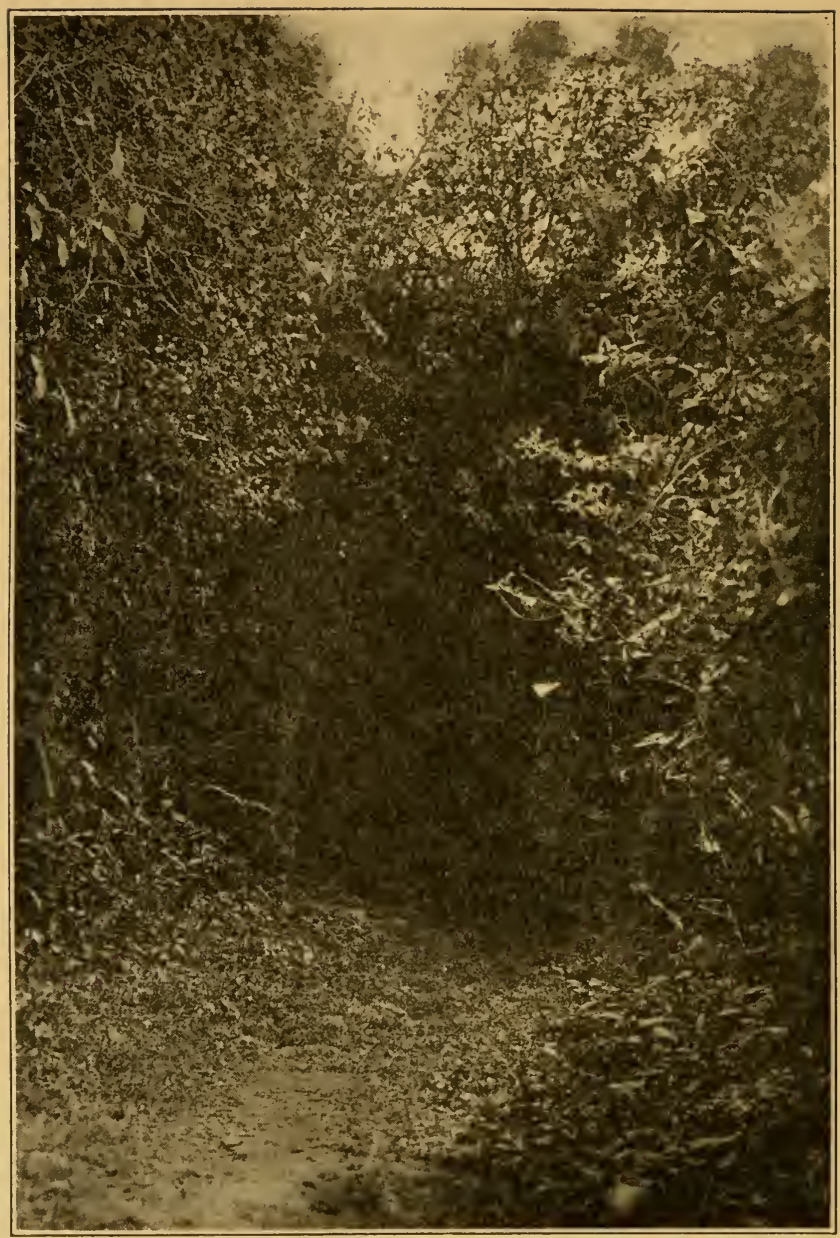

Photograph by Zetek

FIG. 79. Where soldiers and mosquitoes lived together in old Fort San Lorenzo 
With all their care to keep out the "bad air," men went on dying of yellow fever and malaria, but nobody could think of any other cause for so much illness. Panama earned and kept a reputation for being the most unhealthful spot in America. More than three hundred years later, in the time of the French canal diggers, many people still thought that their only chance of preventing these two diseases was to keep their windows closed tight after sunset. And still they died.

It had been learned that great doses of a bitter medicine called quinine, made from the bark of a South American tree, would help to cure malaria. Yellow fever was a different matter. The only treatment for that was to run away from yellowfever patients as fast as possible, or to take the disease intentionally, hoping to have a mild case and get it over with.

A person who has had yellow fever and recovered from it never has it again. The same thing is sometimes true of malaria. Such persons are called immune. Most of the natives of Panama were immune, else they would all have died off long ago.

Those who came in from other countries were not immune. You will remember that the French could not keep enough workmen well to dig the Canal. A third of the men died from yellow fever alone. The governor of Jamaica, where 
many of the best workmen had been hired, refused to let any more men leave the island for the Canal. He said that the government of Jamaica could not afford to take care of these men when so many came home ill, nor to take care of the families they left when they died.

When the United States tried to hire Jamaicans later, it was hard to persuade the governor to let them go. Finally he agreed to do so if the United States would deposit twenty-five dollars with the governor for every man who left the island. The money was to be used to pay for the care of men who came back too ill to work.

The Americans were more hopeful than the governor of Jamaica. They had just finished driving yellow fever out of Havana, where there had been yellow fever month in and month out for more than a hundred and fifty years. They had done it in such an unexpected way that most people were still saying, "It can't be true."

First the Americans had thought that yellow fever was a disease caused by dirt, and they had cleaned Havana until it was the cleanest city in the world. That made no difference with the yellow fever-it grew worse.

Then they listened at last to Dr. Findlay, who had had for twenty years a queer idea about yellow fever, which he could never get any one else to believe. He thought that mosquitoes carried it from one person to another. What 
was more, he thought that only one kind of mosquito was guilty of carrying it. This was a little gray mosquito that we call Aedes.

Three doctors set to work to try out Dr. Findlay's idea. They tried it on themselves, since they did not want to ask any one else to volunteer for so dangerous an experiment. Dr. Carroll let himself be bitten by an Aedes mosquito that had first been allowed to bite a yellow-fever patient. He came down with a severe case of yellow fever from which he recovered. Dr. Lazear was also bitten in the same way. He took yellow fever and died the death of a brave man.

All that year the doctors studied yellow fever and mosquitoes and at the end of the year they were. sure of these facts:

I. Yellow fever is carried by an Aedes mosquito that has bitten a yellow fever patient.

2. It cannot be carried in any other way.

In order to make Havana safe the Americans had two things to do. They had to screen yellow fever patients so that no mosquitoes could bite them and carry the disease to other people, and they had to kill off mosquitoes as fast as they could. When these two things were done, there was no more yellow fever in Havana, and by watching the ships that sailed in from yellow fever ports it was kept out.

It happened that two years earlier an Englishman in India had found that malaria is also carried 
by a mosquito, and that this is the only way that malaria can spread. The malaria mosquito is called Anopheles. I regret to say that neither Acdes nor Anopheles has any short pet name.

The problem in Panama was just the same that it had been in Havana, and the same man, Colonel Gorgas, was placed in charge of it, as well as of the other medical work there. It was very important that the work be done by some one who had learned the ways of malaria and yellow fever mosquitoes, who lead short but interesting lives.

Aedes likes clean, quiet water for her eggs. She prefers to lay them in cisterns of rain water or uncovered jars of drinking water, such as people have around their homes. There the eggs hatch into little wrigglers that live in the water but come to the surface for air. In about ten days after the egg is laid the wriggler changes to a fullgrown mosquito and flies away. Only the mother mosquito bites. She lives about two weeks.

Anopheles, the malaria mosquito, likes clean, quiet country water for her eggs. She lays them in pools or in the grassy edges of streams where little fishes cannot easily push in to reach the eggs and wrigglers. Like Aedes, she does not usually lay her eggs until she has first bitten some animal and had a drink of blood.

Both Aedes and Anopheles may lay their eggs in any bit of quiet water. The moist hollow of 
a leaf or even damp mud will serve for the egg until it hatches a few hours or a few days later, and in Panama, where it rains many days of the year, there may be water standing anywhere out of doors that will do for egg hatcheries.

Mosquitoes do not travel far. If they are killed and the eggs kept from hatching close to towns and encampments, they do not trouble very much. Around the Canal Zone towns the brush was cut down, not only on account of the moisture in the leaves, but because it often hid old pots and cans that held water. Where water and wrigglers could not be emptied or drained away it was sprayed with oil. When the little mosquito wrigglers came to the surface for air, they got the oil in their breathing tubes and choked to death.

The uneven streets of the towns were given new smooth pavement that would not hold puddles of water (Fig. 80). The drains and sewers were kept running freely and treated with mosquito poison every few days.

The buildings were just as carefully inspected. Since the French had not known that mosquitoes were dangerous, they had not been afraid of them. Their big hospital in Ancon had to be cleaned and screened and all the grounds around it cleared to the sunlight.

The French nuns who had nursed in the hospital had been very proud of the beautiful tropical 
garden that they planted on the hospital grounds. And, indeed, it did flourish much better than their patients did. A great pest in this garden was the Attas, the gardening ants, who would strip a whole orange tree of its leaves in a night, to make beds for their own mushrooms. To protect the trees and shrubs from the ants, the nuns had their gardeners put an earthenware ring full of water around the roots of each plant. The water kept the ants away perfectly, because they do not like to swim, but it also made the best of nurseries for yellow fever mosquitoes, so that there were always numbers of them around the hospital. The workmen dreaded to come to the hospital, unless they were already immune, because they were sure to catch yellow fever before they were discharged.

The Americans destroyed thousands of these water rings. Since they wanted to save some of the plants, too, they set to work to kill off the gardening ants. At last both hospital patients and orange trees were safe.

All the houses where Canal Zone employees lived were screened, and the larger buildings were smoked out with insect powder every two weeks, to kill any mosquitoes that might have crept in through cracks and open doors. Colonel Gorgas used that first year all the insect powder he could buy in the United States. None was left on the market. 


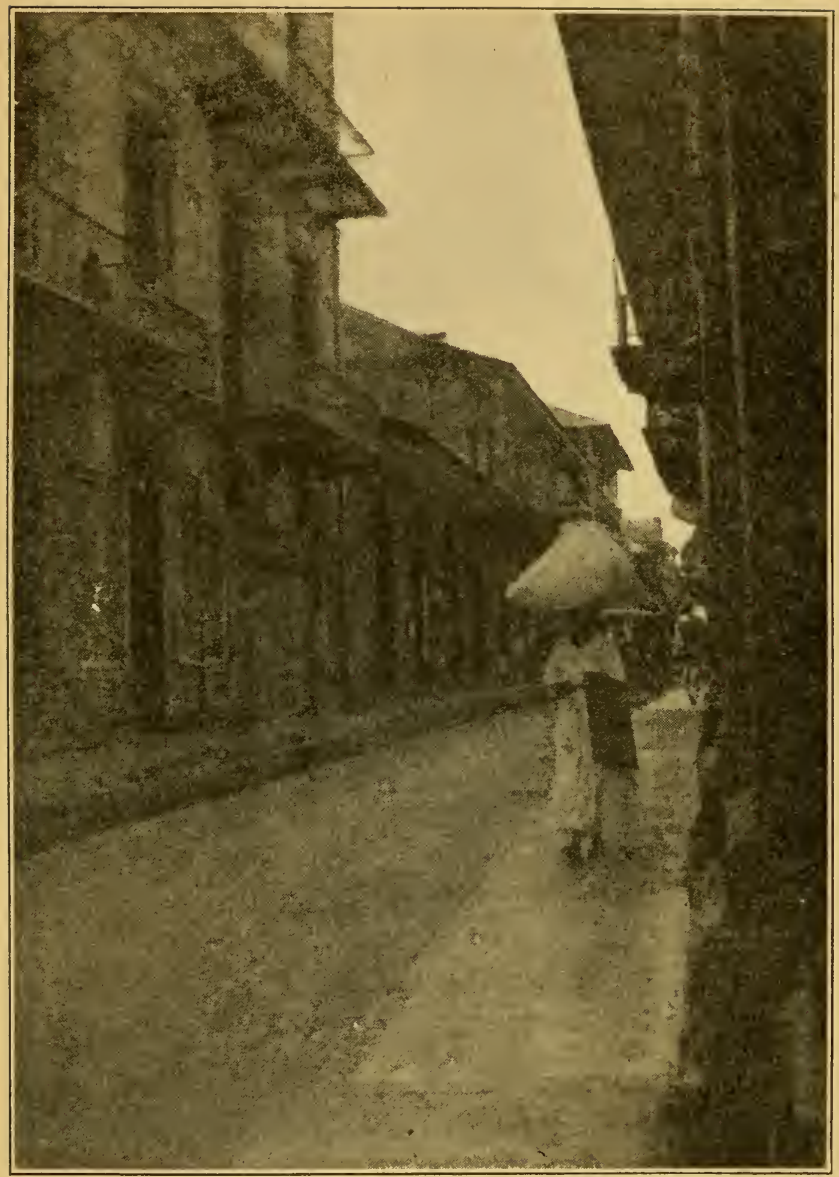

FIG. 8o. Clean paved street in Panama 
The natives were careless, but the Americans knew that they must make the whole Canal Zone safe. They cleaned the rain barrel of the poorest negro as energetically as the cistern of the Bishop of Panama. In the thickly built-up city of Panama, men inspected all houses and yards at least every six days, as fast as a new crop of mosquitoes could come on, and whenever mosquito wrigglers were found they were killed and the water that held them emptied.

With such hard and thorough work it was not many months before the Canal Zone saw the last of yellow fever. Aedes mosquitoes could still be found back in the country, although very few of any kind in the towns, but there were no longer yellow fever patients for them to bite, and so there was no yellow fever to carry.

The men in the sanitary division did not grow careless on that account, because they knew that some one suffering from yellow fever might come into port on a ship at any time and start a fresh epidemic. Nowadays they go ahead ditching ponds and swamps so that stagnant water can run off (Fig. 8I). They see that screens are mended and that water is not left standing in open containers. Many American cities have more mosquitoes than the Canal Zone towns.

Malaria has been much harder to wipe out, and the task is not yet done. Many of the natives have malaria in so light a form that it does not 


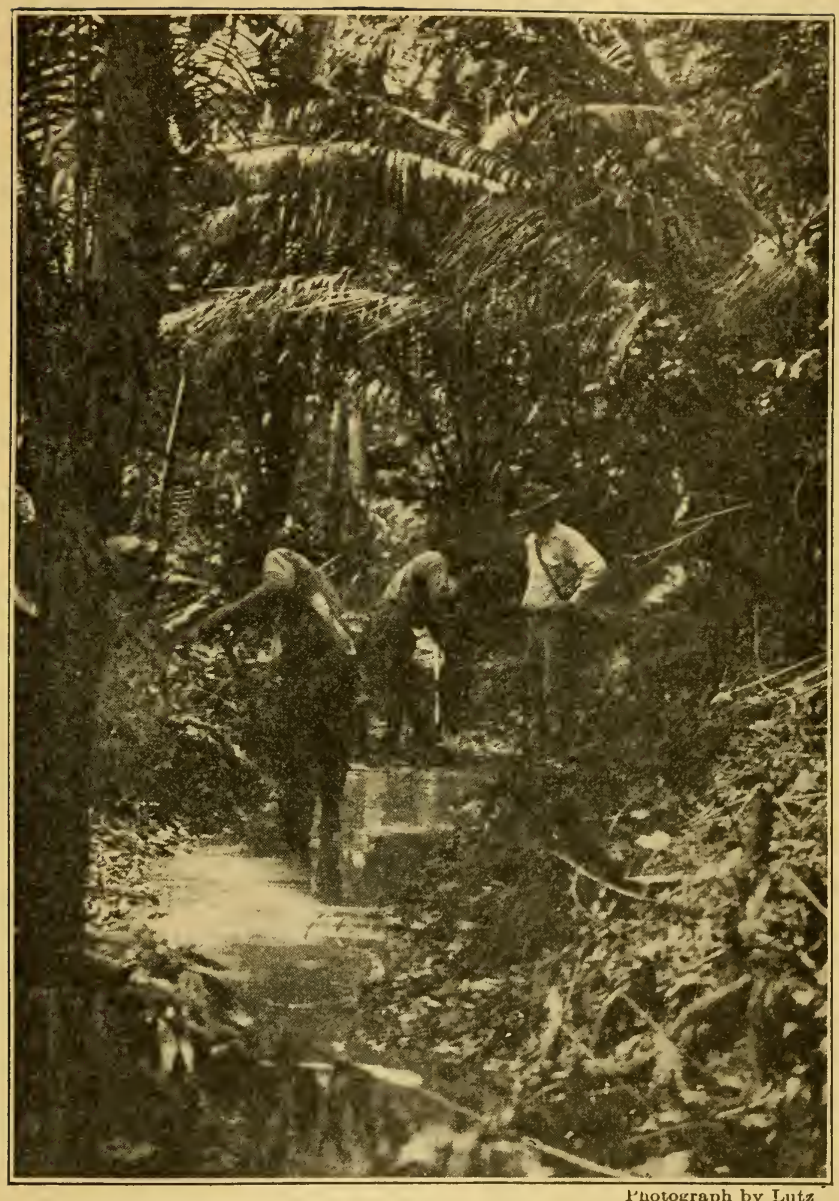

FIG. 81. Drain making by the American Sanitary Service 
really trouble them. They are not careful about keeping their doors closed and avoiding mosquito bites. You can see that it is difficult to keep mosquitoes from carrying malaria from these natives to other people who may be made very ill by it.

However, there is much less malaria and it is not usually of such a violent kind as it used to be. Americans who live in the Canal Zone towns do not often have it, if they are reasonably careful. The old Spaniards used to take pains to shut out the air at night. The Americans have plenty of air, but they are even more careful to keep the screen doors closed against mosquitoes.

Americans who work in the jungle are supposed to take enough quinine to prevent malaria, even if they are mosquito-bitten.

After I had been going out into the bush for about six weeks, the physician at the Ancon hospital dispensary advised me to begin taking quinine, on the chance that I might have been infected by a malarial mosquito by that time. He gave me the advice and the quinine free, just as he would have done for any Canal Zone employee.

The quinine was a liquid, and it was not only the bitterest medicine I have tried, but its taste was the most lasting. The doctor would not give it to me in the nice tasteless capsules that powdered quinine comes in. He said it would not 
do me so much good. I do not approve of chewing gum, but rather than keep the taste of that quinine in my mouth I chewed a whole package of gum after every dose.

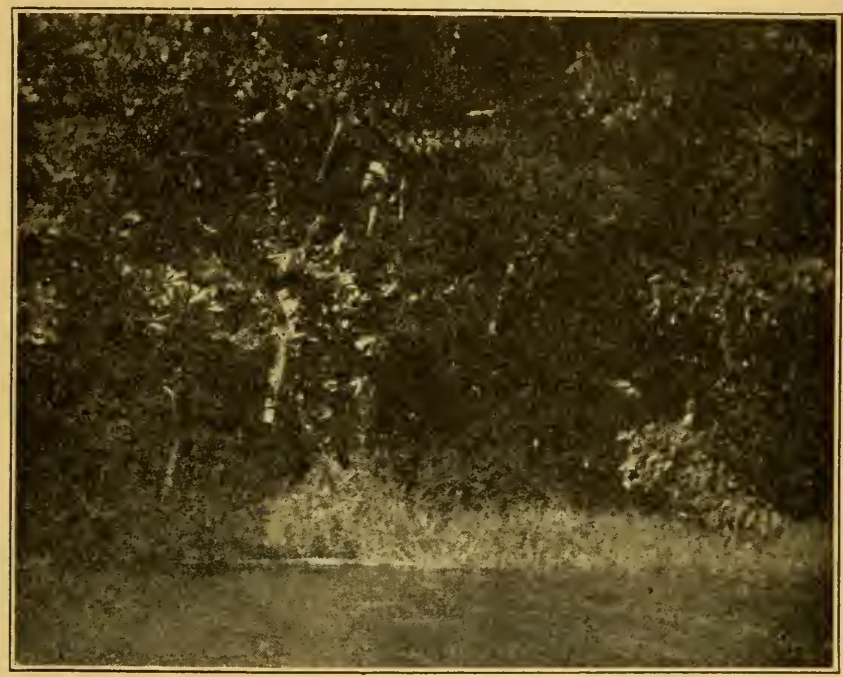

FIG. 82. Grassy shore of Gatun Lake where mosquitoes breed

I met one American who had come to the hospital to be treated for malaria with which he had become infected in the swamps outside the Canal Zone. At the time I saw him, he felt quite well enough to go on about his business, but the hospital was not yet ready to let him go outside the mosquito-free town of Ancon. They intended to keep him there until they were quite certain he had no malaria left in his blood for 
hungry mosquitoes to carry to other people. And they did keep him, though he grew very tired of waiting.

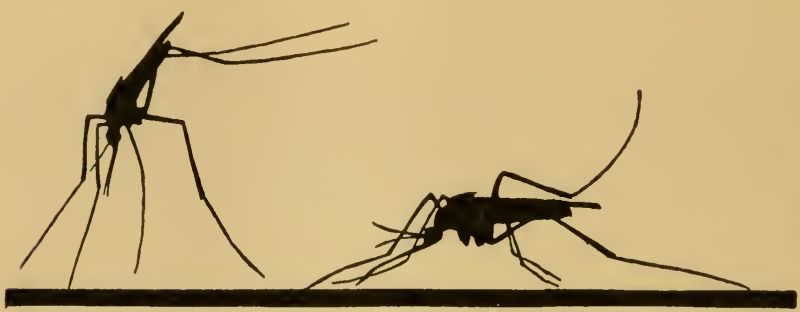

After photograph by Herms

FIG. 83. Mosquitoes poised to bite. Left, malarial mosquito-Anopheles; right, common mosquito

Gatun Lake has not been a troublesome place for the hatching of mosquito eggs, as some people thought it would be. The high winds, coming

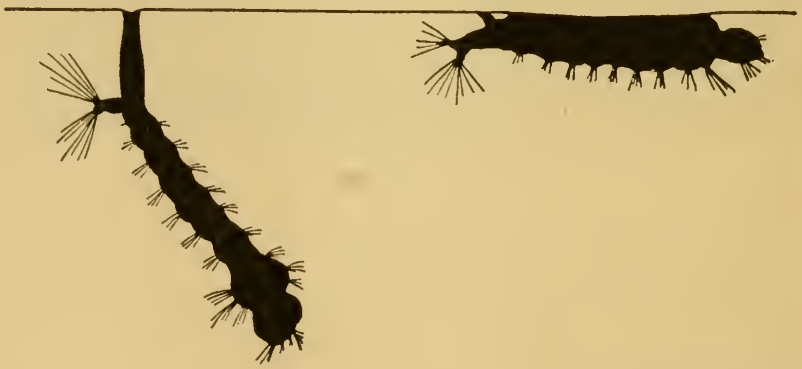

After photograph by Herms

FIG. 84. Mosquitoes hanging to water surface. Right, malarial mosquito larva-A nopheles; left, common mosquito larva (enlarged)

every day, break the surface of the lake into waves and drown the little wrigglers, which, for all that they live in water, must have air. 
But around the edge of Barro Colorado Island the tall grass has begun to grow out into the water from the shore. This breaks the force of the waves and protects mosquito eggs and wrigglers (Fig. 82). They could hatch in the more quiet
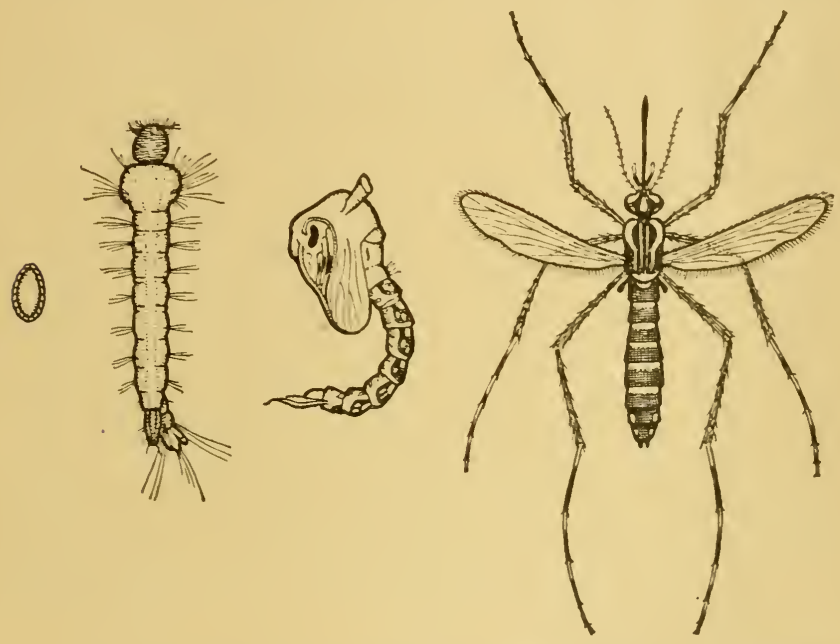

After Howard and Herms

FIG. 85. Egg, larva, pupa, and adult of yellow fever mosquito-Aedes

pools of the little island streams, and I found them in the cups of water held at the base of the thick leaves of some plants.

Among the swarms appearing in the early morning and evening, I found both Aedes and Anopheles, as well as the more harmless mosquitoes that are let alone because they do not carry either disease. 
These two are easy to tell from the others. Look at the picture of Anopheles (Fig. 83) and see her long hind legs, tilting her up when she puts her beak down to bite so that she looks as if she were standing on her head. Our ordinary mosquito stands with its back almost level when it bites.

Aedes is a dark mosquito with the fore part of her body beautifully marked with a silver design like a lyre (Fig. 85). At a little distance she looks gray.

I worked in Panama with several Americans of long experience in the jungle. The large animals interested them but did not alarm them. They were not afraid of jaguars nor of boa constrictors and they spent little thought on poisonous snakes. They feared drinking unclean water, but that they could guard against. What they really dreaded was a bite from an infected little Aedes or Anopheles, with yellow fever or a long, hard case of malaria to follow.

The big and wonderful work of building the Canal could never have been accomplished if Colonel Gorgas and his men had not first learned how to conquer the mosquitoes. Some day, not far off, we hope to be able to say that there is no more yellow fever anywhere in the world. When that old fear and danger is past, and we can go safe from it into any part of the rich tropics, it will be an even more important happening than the building of the Panama Canal. 


\section{MORE BOOKS}

The little clearing around our camp only nicked the edge of the jungle. This little book only peeps over into the lives of the animals we saw there. I cannot think of anything for you to do that would be more fun than to grow up and some day sail down there to the Canal to find out for yourself more about the island. Waiting for you on Barro Colorado are all kinds of interesting things that no one has seen or heard or understood.

And while you are growing up, you may like to be reading more about the jungle and its plants and animals. Here is a list of books written by people who have been in the jungle and really know what they are telling about.

One book is Ants, written by William Morton Wheeler. It is a thick book with many pictures and it tells all about ants all over the world. It is the kind of book you will read a few pages at a time, pausing between readings to think about what you have read.

Reptiles of the World, by R. L. Ditmars, has stories and pictures of snakes and lizards and the like. It is a rather new book.

I do not know any writings that give you the feeling of the jungle so well as Jungle Peace and 
The Edge of the Jungle, written by William Beebe about South American jungle.

The oldest and best known book on Central American jungle is The Naturalist in Nicaragua, written years ago by an English mining engineer, Thomas Belt. It is both interesting and truthful, and nothing better can be said of a book. Most naturalists still quote from it, as I have done.

If you like pirates as well as jungle life, you will never find a more exciting pirate tale than that of Morgan and his raids across the Isthmus after Spanish gold, and the stories of Sir Francis Drake are almost as thrilling.

Pirates of Panama was written by John Esquemeling, who was with Morgan himself. Two other books that are a little easier to read are The Boy's Book of Buccaneers, by Eric Wood, and The Real Story of the Pirate, by A. Hyatt Verrill. All three are well illustrated, as they deserve to be. 


\section{SUGGESTIONS TO TEACHERS}

\section{GROUP DISCUSSION}

Informational value of silent reading. In preparing this account of life in the rainy tropics we have been animated by a firm belief in the informational value of silent reading and the necessity for acquiring, while still in school, the habit of reading informational matter. We remember the information and pleasure received from such reading in our own grade-school days and regret that we were never allowed time to talk over what we had read and so fix impressions or correct wrong ideas. We suggest supervised group discussion where the teacher may be sure that the children will be encouraged to talk over the material informally together.

Exploration clubs. Such encouragement might well result from dividing the class into exploration clubs each one of which is asked to discuss informally and decide which of the experiences recorded in Jungle Island they would most like or dislike to meet with; which of the animals they would most desire to see; which they would fear most; which they think would prove most useful to a person alone on a jungle island. Each club should then-report through a chosen leader to the entire group. Once he is away from the Canal Zone towns, a man's supplies are limited. What things do the children think necessary for a week's stay on Jungle Island? 


\section{HISTORY AND GEOGRAPHY}

Building of the Panama Canal. In the future we of the temperate regions of the earth shall turn more and more to the tropics for food, lumber, fuel, and other necessities. It is well for school children to come to have a correct attitude toward and understanding of tropical life and of the conditions under which work can successfully be carried on there. In this connection, and with the background furnished by reading Jungle Island, classes might study the building of the Panama Canal as an example of successful work in the tropics.

Most children of the junior-high-school age already know something about the Panama Canal and its building. Nearly all such information can be worked into this theme. Those who have no personal connection with the Americans in the Canal Zone will find the old files of the National Geographic Magazine through the ten years the Canal was being builtI904-I9I4-well supplied with interesting illustrated articles.

Map work and sand modeling. We believe it would be well for the children to make either a rough sketch map of the continents with the Canal located, or a sand model of the Canal itself. Some children will take great interest in making fairly accurate profile maps or models of the Canal, with its two sea-level, seven-mile entry ways and its middle section of fresh water eighty-five feet higher, reached from the Atlantic side by the three pairs of locks at Gatun and on the Pacific side by the two pairs at Miraflores which connect that sea-level stretch with Miraflores Lake fifty- 
five feet higher. A mile farther are the Pedro Miguel Locks, which consist of a single pair, with a lift of thirty feet.

The Pacific half of the mid-section should be shown as a narrow cut through hills, which extends nine miles to Gatun Lake. The highest of these hills stand approximately one thousand feet above sea level, although the pass through which the Canal was dug was only three hundred feet above sea level. The relation of the Canal to Gatun Lake and to Barro Colorado (Jungle) Island as well as to these other features may be seen on the map on page I I. A generalized profile is given as an aid in the supervision of such efforts (page I 5 ).

Insect-borne diseases. When the engineering difficulties of digging the Panama Canal have been firmly fixed, the teacher should make a point of the greater obstacles involved in the insect-borne diseases as outlined in the last chapter. The story of Colonel Gorgas himself (Sanitation in Panama, I9I5) may be read and told in as much detail as time permits.

Study of climate. Almost all the differences between tropical and temperate climates may be truthfully brought out in such a story. Some of these differences are illustrated in the table on page 200 , taken from a report by Mr. R. Z. Kirkpatrick, chief of the Division of Hydrography and Meteorology of the Canal Zone.

Rainy season. In parts of the rainy tropics there is no cessation of the rainy season, but in much of this region, the world over, the rains are interrupted for a longer or shorter dry season. Thus in Panama during January, February, or March there is about the same quantity of rain that we have in Chicago in 
a month; but during the remainder of the year there is much more, and November alone averages a greater number of inches of rainfall there than Denver has in a whole year. Rains yielding as much as six inches of water are rare, but occasionally eight inches of rain or more may fall in a single day.

Difference between Tropical and Temperate Climates

\begin{tabular}{|c|c|c|c|c|c|}
\hline \multirow{3}{*}{ Stations } & \multicolumn{3}{|c|}{ Record Temperatures } & \multirow{3}{*}{$\begin{array}{l}\text { AVERAGE } \\
\text { ANNUAL } \\
\text { RELATIVE } \\
\text { HUMIDITY }\end{array}$} & \multirow{3}{*}{$\begin{array}{l}\text { AVERAGE } \\
\text { ANNUAL } \\
\text { RAINFALI }\end{array}$} \\
\hline & \multirow{2}{*}{$\begin{array}{c}\text { Average } \\
\text { July } \\
\text { Temp. }\end{array}$} & \multicolumn{2}{|c|}{ Any Month } & & \\
\hline & & Highest & Lowest & & \\
\hline Mobile........... & 80 & I 02 & $-\mathbf{I}$ & 79 & 62.0 \\
\hline Denver.......... & 72 & 105 & -29 & 52 & 14.0 \\
\hline Washington........ & 77 & I O4 & - I 5 & 72 & $43 \cdot 5$ \\
\hline Key West......... & 84 & 100 & $4 I$ & 78 & 38.7 \\
\hline Chicago......... & 72 & IO3 & -23 & 74 & $33 \cdot 3$ \\
\hline New York ......... & 74 & IOO & -13 & 72 & 44.6 \\
\hline New Orleans...... & $8 \mathrm{I}$ & IO2 & 7 & 78 & $57 \cdot 4$ \\
\hline St. Louis...... & 79 & 107 & -22 & 70 & $37 \cdot 2$ \\
\hline Boston ......... & 71 & 104 & -14 & 72 & $43 \cdot 4$ \\
\hline San Francisco...... & 57 & IOI & 29 & 80 & 22.3 \\
\hline Oklahoma......... & 80 & 108 & -17 & 70 & $3 I \cdot 7$ \\
\hline Charlestown, S.C. . & $8 I$ & 104 & 7 & 78 & $52 . I$ \\
\hline Galveston......... & 83 & 99 & 8 & $8 I$ & $47 \cdot$ I \\
\hline Norfolk........... & 78 & $\mathrm{IO} 2$ & 2 & $\ddot{0}$ & $49 \cdot 5$ \\
\hline & 80 & 93 & 66 & 84 & 127.8 \\
\hline
\end{tabular}

Humidity. Even during the driest times of the year the humidity is so high that one must keep an electric light bulb burning continually in each closet to dry out and keep from mold the clothes and shoes stored there. A cloudless day is rare in the dry season, and in the rainy season the sky is overcast more than half the time.

Variety of climate in Canal Zone. However, one must not conclude that there is only one tropical 
climate. There are almost as many varieties as there are localities. For instance, the north entry of the Canal is much more rainy than the south end less than fifty miles away, because the intervening hills help to precipitate the rain from the moist winds off the Caribbean Sea. Not nearly all the tropics are as rainy as the country we describe here, but the most fertile tropics are the most humid and they are also the most troubled by insect pests.

Commercial geography. We suggest also that the Canal be considered as a commercial trade route, and that the children search the markets for fruits, such as bananas, avocado pears, or coconuts, that might have come from its general region. Such exercises could be admirably illustrated from the folders of steamship companies plying to the Canal and the shores of countries bordering the Caribbean Sea. These are advertised in almost any good magazine.

\section{NATURAL HISTORY}

Importance of insects. After the dramatic story of the contest between man and mosquito for the mastery of the tropics has been discussed, the student may proceed more easily to the importance of other insect families like the ants and the termites. It is of course true that in the temperate zone as well as in the tropics, insects are in the ascendancy among animals. One has only to recall the growing list of fruit and grain pests, not to mentiòn flies and our own malaria-bearing Anopheles mosquito. The children should be able to make a list of familiar harmful insects which we do not have under control; and they may well 
draw their own conclusions about their eradication, using the story of the wiping out of yellow fever as an inspiration as to possibilities.

Visiting museums. Where a museum is available, the children should go to see for themselves specimens of the larger birds and of animals mentioned and. bring back full descriptions.

Our great interest throughout is that the child shall come to regard the whole world as his own, and feel himself at home in the tropics, as in the temperate regions. 


\section{GLOSSARY}

Pronunciation of the following words is taken largely from Webster's Dictionary, from which the key to pronouncing symbols is also derived.
$\bar{a}$ as in āle
$\bar{o}$ as in ōld
à as in senăte
$o$ as in obey
â as in câre
$\hat{o}$ as in ôrb
ă as in ăm
ŏ as in ŏdd
ä as in ärm
à as in ảsh
$\bar{u}$ as in use
$\hat{\mathrm{u}}$ as in unite
$\bar{e}$ as in eve
$\hat{a}$ as in ûrn
è as in event
$\breve{u}$ as in ŭp
ĕ as in ĕnd
ẽ as in makẽr
oi as in oil
ou as in pound
$\mathrm{I}$ as in ice
1 as in 111

A

acetylene (à-sĕt'̂-1ēn). A gas used to make a light in our head-lantern.

Aedes (é'dēz). The mosquito that carries yellow fever, formerly called Stegomya (stĕg-ò-mī'yà).

Ancon (ăn'cŏn). Ancon and Balboa house the workers at the Pacific end of the Panama Canal. Ancon also adjoins the town of Panama.

Anolis (à-nō'llis). A small lizard with changeable skin colors and a throat that can be puffed out into the shape of a half-dollar.

Anopheles (à-nŏf'ê-lezz). The mosquito that carries malaria. 
antennae (ăn-tĕn'ẽ). The feelers on the head of an insect. They usually look like stiff hairs.

armadillo (är-mà-dı̆l'ō). A four-footed warm-blooded animal with a hard shell.

Atta (ät'ä). The gardening ant.

Azteca (ăz'těk-a)). The paper-making ant.

\section{B}

Balboa (bäl-bō'ä). The town where American employees live at the Pacific end of the Canal.

Barro Colorado (bär'ō kŏ-lò-rä'dō). The jungle island formed by the rising of the waters of Gatun Lake. These completely surrounded a high hill and made an island of it. basiiisk (băs'1-lissk). The water-walking lizard. buoy (boi). A float marking safe channel for ships.

\section{C}

caiman (kā'măn). A kind of tropical alligator.

camouflage (kă'mō-fläzh). To disguise.

capuchin (kăp'tu-chĭn). A monkey with black on the head like the dark hood of a monk.

Caribbean (kăr-1̆b-bē'ăn). The sea between the West Indies and Central and South America.

casa grande (kä'sä gränd'ā). Spanish, meaning a large house. cayuca (kä-yū'kä). Panamanian name for a canoe hollowed out of a $\log$.

Chagres (chä'grĕs). The Panamanian river whose waters fill Gatun Lake and make the greater part of the Canal. coati (kö-ä'tè). A tropical raccoon-like animal, but with a larger tail and a long and very flexible snout.

Colon (kō-lōn'). The city at the Atlantic end of the Panama Canal. The name was formerly Aspinwall. 
conejo (kठ́na $\left.\bar{a}^{\prime} h \bar{o}\right)$. A relative of the guinea-pig in the rainy tropics that lives in holes during the day and comes out for food at night.

cormorant (kôr'mỏ-rănt). A large swimming and diving bird called in Panama a fish duck.

corozo (kò-rō'sō). A kind of palm tree.

Culebra (kō-1ā'brä). The name of the cut made through the hills between Gatun Lake and the Pacific Ocean. The town near by has the same name.

curassow (kū'rả-sō). A large bird, which is related to our domestic fowls.

\section{D}

dinosaur (dín'ot-sôr). A gigantic lizard-like animal that once lived on the earth but is no longer found.

\section{E}

Eciton (ĕs'1̌-tŏn). The army ant. entomologist (ĕn-tò-mŏl'ò-jisst). A person who studies insects.

\section{F}

fer-de-lance (fâr-dẽ-läns). A poisonous snake.

fertilize (fûr'tr̆-lĩz). To make rich, as soil for plant growth. formalin (fôr'mà-linn). A preserving liquid.

Frijoles (frē-hō'lĕs). A small town on Gatun Lake noted for its fine bananas. One embarks there for Barro Colorado Island.

Frijolita (frē-hō-lē'tä). A little river whose bed is now largely covered by Gatun Lake.

fumigate (fū'ml̆-gāt). To smoke out bacteria, insects, or larger animals. Sulphur is often burnt to make the smoke. 
G

Gamboa (gäm-bō'ä). The town where the Chagres River empties into Gatun Lake.

Gatun (gä-tōon'). Gatun Lake, made by the Chagres River waters, joins the two sea-level entries of the Panama Canal.

Gorgas (gôr'gàs). Colonel Gorgas directed the campaigns that freed Cuba and Panama from yellow fever.

gotosola (gō-tō-sō'lä). A raccoon-like, four-footed animal. See coati.

guanaco (gwā-nä'kō). The largest wild llama, a distant relative of the camel.

guayacan (gwä-yä-kän'). A yellow-flowering hardwood tree found in Central America.

\section{$\mathrm{H}$}

heliconia (hĕl-ı̆-kō'nı̆-á). A long-leafed plant, much like a very large canna.

iguana (ŭ-gwä'nå). A large lizard living in the warm parts of America. It grows to be five feet or more long. It is very often eaten by the natives.

\section{$\mathrm{J}$}

jacana (jăk'à-nä). Birds with long legs and particularly long toes which make it possible for them to run along the lily pads floating on the water.

jaguar (jăg-wār'; jà-gwär'). The largest and most dangerous wild cat in America, mostly limited to forested tropical regions.

Jamaica (já-mā'kà). An island in the West Indies which belongs to Great Britain. It is located ninety miles south of the eastern part of Cuba. 


\section{L}

liana (lè-ä'nà; lı̆-ăn'à). A general name for the climbing and twining plants in tropical forests.

Lorita (1ò-rē'tä). Spanish, meaning "little parrot."

\section{M}

macaw (má-kố ${ }^{\prime}$. A large, especially gaudy parrot with the face partly bare of feathers.

machete (mä-chā'tā). A long heavy knife used in SpanishAmerican countries as a tool and a weapon.

manakin (măn'à-kı̆n). A small thickset bird with brilliant plumage. It is native to the hottest parts of America. marmoset (mär'mò-zĕt). A small squirrel-like monkey, ranging from a few inches to a foot long. It lives in the forests of tropical America and feeds on insects. It makes an amusing pet.

Miraflores (mē-rä-flō'rās). The name of the two pairs of locks nearest the Pacific side of the Panama Canal, and of the mile-long lake above them.

Molino (mò-1ē'nō). The name of a young Panamanian naturalist who helped us.

mosquito (mŏs-kē'tō). One of the many different kinds of gnats and midges. The female bites animals and draws blood. Some kinds carry disease germs, such as yellow fever and malaria.

motmot (mŏt'mŏt). A tropical bird that trims its two longest tail feathers, leaving an end the shape of a tennis racket.

mucho malo (mō'chō mä'lō). Spanish for "very bad."

\section{N}

ñequi (ně'kē). A relative of the guinea pig. It lives in burrows and on the jungle floor in warm parts of America. 
O

ocelot (ō'sè-lŏt). The leopard cat of America. It is from three to four feet long. About one foot of this length is tail. The color is grayish marked with dark spots. It is found as far north as Texas and south into South America.

opossum (ō-pŏs'ŭm). Tree-dwelling animals varying in size from the bulk of a large cat to that of a rat. They have a well-known trick of playing dead-" "playing possum" -when caught. On the under side of her body the female has a pocket like the pouch of a kangaroo in which she carries her babies.

\section{P}

Panama (pă-nä-mä'). A Central American republic covering the Isthmus of Panama; once a part of the Republic of Colombia.

papaya (pä-pä'yä). A small tree with fruit like a melon. parrakeet (păr'á-kēt). A small bird belonging to the parrot family.

patois (pà-twä'). A dialect.

peccary (pěk'à-ř́). The wild pig common in Central and South America. They extend north into Texas.

Pedro Miguel ( $p \bar{a}^{\prime}$ drō mē-gĕl'). The locks at the Pacific end of Gatun lake.

pelican (pĕl'̌̌-kăn). A large water-bird with a great skinny pouch under its bill.

peripatus (pě-rịp'à-tŭs). A curious wormlike animal that is

- half worm and half insect.

porcupine (pôr'kut-pīn). A four-legged animal bristling with spines.

Porto Bello (pōr'tò běl'ō). An old Spanish town on the Caribbean coast of Panama. A great fair and market was held here every year. 
potassium permanganate (pò-tăs'1̌-ŭm pẽr-măng'gả-nāt). A chemical used to wash wounds made by snake bite.

protozoa (prō-tò-zō'à). The most simple form of animal, with only one body cell.

\section{R}

rhinoceros (rī-nŏs'ẽr-ŏs). A thick-skinned, four-legged animal, usually with a horn or two on its blunt nose. It lives in tropical Africa.

rodent (rō'dĕnt). A furry animal, whose teeth are especially well fitted for gnawing. Rodents are of many sizes and kinds and live in nearly all countries and climates. Rats and mice are rodents.

\section{$\mathrm{S}$}

San Lorenzo (sän lò-rĕn'thō). An old Spanish fort on the Caribbean coast of Panama, at the mouth of the Chagres River.

scorpion (skôr'pŭ-ŭn). A relative of the spiders, with a long jointed body bearing a poisonous sting at the end. See Figure 40 on p. 9 I.

\section{T}

tamales (tà-mä'lĕs). Cakes made of cornmeal and meat seasoned with red peppers.

tapir (tā'pẽr). A hoofed animal somewhat like a giant hog. Those in Panama grow to weigh almost a ton.

tarantula (tà-răn'tù-là). Any one of the great hairy spiders of the warmer parts of America.

termite (tûr'mit). So-called "white ants," which are not ants at all though they live in similar colonies. They usually eat wood and are especially destructive on account of their habit of eating out the centers of solid timber and furniture, leaving only a crumbling shell.

tigre (tét'grā). A native name for any large catlike animal. 
tinamou (tı̌n'à-mō). A bird much like a partridge.

toucan (tō-kän'; tō'kăn). A large, strikingly marked bird with a much oversized bill.

\section{V}

vacuum (văk'tu-ŭm). A place with no air. Many animals have pads on their feet which they can make into partial vacuums and so cling to trees or walls just as a vacuum cleaner clings to a rug and lifts it up.

Y

yaguarundi (yä-gwả-rŭn'dǔ). A large wild cat.

Z

zoőlogical (zō-ô-lŏj'ı̌l-kăl). About animals. For instance, a zoölogical park is a park with animals in it. 


\section{THE INDEX}

Aedes, yellow fever mosquito, I 82,184

at Barro Colorado, 193

description of, 194

how driven from Canal Zone, I 85 ff.

Aeroid plants, 49, 50

Alligators, I I 8

American restaurant in Ancon, 23

Americans:

malaria driven from Canal Zone by, 9, I $88 \mathrm{ff}$.

yellow fever driven from

Canal Zone by, 9, $185 \mathrm{ff}$. yellow fever driven from Havana by, 182,183

Ancon, 20

American restaurant in, 23 hospital, I $85 \mathrm{f}$. temperature in, 20

Animals:

furry, I $59 \mathrm{ff}$. See also various animals

migration of, caused by making of Gatun Lake, I6

Anolis, $126 \mathrm{ff}$.

color change of, I28, I30

relatives of, 136

Anopheles, malarial mosquito, I 84

at Barro Colorado, 193

description of, 194

Anteaters, 8I

Ants, 54 ff.

army, or Ecitons, $65 \mathrm{ff}$.

Attas, $56 \mathrm{ff}$.

Azteca, $63 \mathrm{f}$.

black, 62

Congo, 62

Ecitons, $65 \mathrm{ff}$.

in termite nests, $85 \mathrm{ff}$. spinning, 64

stinging, $6 \mathrm{I}$

white. See Termites

Ants, by William Morton Wheeler, 195

Armadillo, I64 ff.

Attas, 56 ff.

care of young, $60 \mathrm{f}$.

food of, 56

gardening of, $58 \mathrm{ff}$.

in Ancon hospital garden, I 86

kinds of, $5^{8}$

nests, $57 \mathrm{ff}$.

Azteca ants, $63 \mathrm{f}$.

nests of, 63

Balboa, discoveries of, I

Balboa, town, 26

Bananas, importance of, 27

Barro Colorado Inlet, $34 \mathrm{ff}$.

Barro Colorado Island:

a forest preserve, $\mathbf{I} 7$

making of, 17

trees on, 38

Basilisk lizards, $132 \mathrm{ff}$.

Bats, I 70

Beebe, William, I 55, I95, 196

Bell bird, 154

Belt, Thomas, I47, I56, I60, I63, I76, 196

Birds, I $37 \mathrm{ff}$. See also various birds

Black snake, I I I, I I 2

Blunt-headed snake, I I3 f.

Boa constrictor, I 08

Boy's Book of Buccaneers, by Eric Wood, 196

Bushmaster, I Io

Caimans, II 8, I20 f. food of, I 22 
Camel family, extinction of, in North America, I3

Canal. See Panama Canal

Canal Zone:

climate of, $199 \mathrm{ff}$.

engineers in, II, I 2, I 4 geology of, $12 \mathrm{ff}$.

Capuchin monkey, $162 \mathrm{ff}$.

Carroll, Dr., 183

Casa grande, 30

Catfishes, I3

Cattle, 27 attacked by ticks, 102

Cayuca, 29

Chagres River:

at flood time, 26

bed of Gatun Lake, Io, I6 important to travel, 2,5

Chameleon, 136

Chicken cat, or yaguarundi, $167 \mathrm{f}$.

Climate of Canal Zone, $199 \mathrm{ff}$.

Coati, I6o f. hunting iguanas, I6of.

Colon, Canal begun at, 10

Columbus, landing at Isthmus of Panama. I

Commercial geography, 20 I

Conejo, 170

Congo ants, 62

Coral snakes, I 12

Cormorants, 142

Crocodile eggs, 20, I I 8

Crocodiles, I $7 \mathrm{ff}$. home of, I 18

Culebra Cut, 26

Curassow, I 50

\section{Deer, 174} scarcity of in South America, I 3

Dinosaur, 124, 132

Diseases, insect-borne, 199

Ditmars, R. L., 128, 195

Eciton ants, $65 \mathrm{ff}$. food of, 66 nests of, $66 \mathrm{f}$.
Edge of the Jungle, by William Beebe, 196

Empire, 26

Engineers in Canal Zone, Io, I2, 14

Esquemeling, John, 196

Exploration clubs, 197

Fawn, 174

Fer-de-lance, I 10

Fern vines, 44

Findlay, Dr., 182, 183

Fish ducks, or cormorants, 142

Fort San Lorenzo, 170, I79

Frijoles, 27, 30

old village of, 34

Frijolita River, 34

Gamboa, 26

Gatun Dam, 14, 16

Gatun Lake:

Barro Colorado result of, 17 crocodiles in, $I I 7, I I 8$

forest destroyed by, 30

making of, I0, 16

migration of animals caused by, 16

Gatun Locks, 10

Geology of Canal Zone, I I ff.

Glossary, 203

Goat sucker, I 44 f.

Gold:

discovered in California, 8 taken by Spanish explorers in Central America, I, 7

Gorgas, Colonel, I84, 186, I94, 199

Gotosola, or coati, I $60 \mathrm{f}$.

Grackles, I 4 I

Granddaddy-long-legs, or harvestman, $96 \mathrm{ff}$.

Guanaco, I3

Guayacan trees, 50

Hangbird, I $45 \mathrm{f}$.

Harvestman spider, $96 \mathrm{ff}$.

Havana, yellow fever driven from, 182 
Hawks, I4I, I 42

Heliconia, I 70

Heron: blue, 143 green, I $43 \mathrm{f}$.

History and geography work, 198

Howlers, I 7 I f.

Humidity of Canal Zone, 200

Humming birds, I $55 \mathrm{f}$. tongue of, 156

Iguanas, $134 \mathrm{f}$. as a food, I 35 hunted by coatis, I6o f.

Indians on Isthmus of Panama, I, 3,7

Insects, importance of, $20 \mathrm{I}$

Isthmus of Panama:

climate, 3

early roads of Spaniards across, $2 \mathrm{f}$. location, I, 2 of gold hunters in 1849 across, 8

under water thousands of years ago, I3

Jacanas, I4I

Jaguar, I 64

Jamaica, canal workers from, I 82

Jungle:

plant growth in, 44 temperature in, 52

Jungle Peace, by William Beebe, I 95

Jungle roof, $43,50,52$

Kingfishers, 142

King's highways, 2, 8

Kirkpatrick, Z. R., cited, 199

Ladder made of spikes, $38 \mathrm{ff}$.

Lazear, Dr., 183

Lianas, $39,47,48$
Lizards, $123 \mathrm{ff}$. ancestors of, $123 \mathrm{f}$. Anolis, $126 \mathrm{ff}$.

basilisk, I $32 \mathrm{ff}$. descendants of, 124 loss of tail, I $30 \mathrm{ff}$.

Llama, I3

Logging in the jungle, $5 \mathbf{I}$

Long-headed tree snake, I I 5 Lorita, $148 \mathrm{f}$.

Macaw, I 47

Machete, 39

Mahogany trees, 5I

Malaria, I $79 \mathrm{ff}$.

how combated in Canal Zone, I $88 \mathrm{ff}$.

in days of Spanish explorers, in India, 183

successfully treated by the Americans, 9

Manakins, 137,154

Map work, 198

Marmosets, $173 \mathrm{f}$.

Marty, Captain, 164

Miraflores Locks, Io, 26

Milk in Canal Zone, IO2

Milkweed, 44

Monkeys, $162 \mathrm{ff}$.

black howlers, 17 I f.

capuchin, $162 \mathrm{ff}$.

marmosets, $173 \mathrm{f}$.

night, $\mathrm{I} 72 \mathrm{f}$.

Morgan, Henry, raids of, $6 \mathrm{f}$., 179

Mosquitoes:

conquest of, I $79 \mathrm{ff}$.

eggs laid in water, I84, 193 how driven from Canal Zone by Americans, $185 \mathrm{ff}$. Motmot, I 37, I $53 \mathrm{f}$.

"Mountain cows." See Tapirs

Mushrooms of Attas, $58 \mathrm{ff}$.

Natural history, 201

Naturalist in Nicaragua, by Thomas Belt, 196 
Nequi, $169 \mathrm{f}$.

Night monkey, I $72 \mathrm{f}$.

Ocelot, I 64

Orchids, 50

Orioles, I 45

Pacific Ocean, discovered by Balboa, I

Palms, $44 \mathrm{f}$.

Palm sail, 32

Panama Canal:

building of, 198

completed by United States, 9 ff.

French plan for, 8,10

geological conditions to be overcome in digging of, I I ff.

highway, a, 34

Spaniards, plans for, 5

Panama City:

effect of modern sanitation on, $185 \mathrm{ff}$.

unhealthful, I 8 I

Morgan's raid on, 7

Panama, Isthmus of.

Isthmus of Panama

Panama railway, route of, $25 \mathrm{f}$.

Papaya melon, 23

Paper-making ants, $63 \mathrm{f}$.

Paradise bird, or tinamou, I44

Parrakeets, I 49

Parrots, $147 \mathrm{ff}$.

Passion vine, 44

Peccary, or wild pig, I64, I66 f.

Pedro Miguel Locks, 26

Pelicans, 139

Peripatus, $103 \mathrm{ff}$.

Peru, gold from, I

Pirates, English, 6, 7

Pirates of Panama, by John Esquemeling, 196

Poor-me-one, I $44 \mathrm{f}$.

Porto Bello, importance of, 6 Protozoa, 77

Quinine, as cure for malaria, I 8 I, I 90
Railway, Panama, $25 \mathrm{f}$.

Rainy season, $199 \mathrm{f}$.

Real Story of the Pirate, The, by A. Hyatt Verrill, I96

Red bugs, 99, I O I

Reptiles of the World, by R. L. Ditmars, 195

Roads:

early, across Isthmus of Panama, $2 \mathrm{f}$.

machete-cut trail, 152 of gold hunters in 1849,8

Rodents:

bats, 170

conejos, I 70

in North America and South America, 13 nequis, I $69 \mathrm{f}$.

Sand-box tree, 39

Sand modeling, 198

Sanitation in Panama, by Colonel Gorgas, 199

Scorpions, $89 \mathrm{ff}$. sting of, 92

Seed ticks, 100

Sentinel tree, 5 I

Silent reading, value of, 197

Sloth, $176 \mathrm{ff}$.

Snake bite, 107 cure for, I Io

Snakes, Io7 ff. See also various snakes

danger from, I I 7

enemies of, I 16

home of, II 6

poisonous, 2I, 107, 108, IIo,

I I 5, I I 7

temperature of, I I $5 \mathrm{f}$.

Snow-hooded bell bird, I54

Spaniards:

at Isthmus of Panama, I

plans for Canal, 5

road building by, $2 \mathrm{f}$.

Spanish bayonet palm, 37

Spiders:

bird-eating, or tarantula, $92 \mathrm{ff}$.

bite of, 96 
harvestman, $96 \mathrm{ff}$. scorpions, $89 \mathrm{ff}$.

Spike ladder, 38 ff.

Spinning ants, 64

Squirrel, I69

Stilt palm, 45, 68

Tapirs, I62, I64, I $75 \mathrm{f}$. attacked by ticks, IOI

Tarantulas, $92 \mathrm{ff}$.

nest of, 93

bite of, 96

Tarantula hawk, $93 \mathrm{ff}$.

Teachers, suggestions to, $205 \mathrm{ff}$.

Temperature:

in Ancon, 20

in the jungle, $5^{2}$

Termites, $68 \mathrm{ff}$. ant enemies of, 85 fi. destructive habits of, $78 \mathrm{ff}$. enemies of, $75,8 \mathrm{I}, 85$

food of, $76 \mathrm{ff}$.

injuries done by, $78 \mathrm{ff}$.

kinds, $74,83,85$

mound nests of, 83

nests of, $68,70,83$

runways or road building, $70 \mathrm{f}$.

\section{soldiers, 73}

useful work of, 81,83 wood-digesters, or Protozoa, 77 works, 73

Ticks, 5, $99 \mathrm{ff}$. removal of, roo

"Tigre," I64
Tinamou, I44

"Torkeys," I 50

Toucans, $156 \mathrm{ff}$.

Tree viper, $108 \mathrm{ff}$.

Trees, size of, 38

Turkeys, I 50

Turtle attacked by ticks, Ior

Verrill, A. Hyatt, 196

Viper, $108 \mathrm{ff}$.

Vultures, $138 \mathrm{f}$., $142 \mathrm{f}$.

Wasp. See Tarantula hawk Water, necessity for boiling, 29 Water vine, 48

Wheeler, William Morton, 195 Whippoorwill, I $44 \mathrm{f}$.

White ants. See Termites.

Wild fig, $47 \mathrm{f}$.

Wild pig, or peccary, $164,166 \mathrm{f}$. Wood, destroyed by termites, $78 \mathrm{ff}$.

Wood, Eric, 196

Woodpecker, I 42

Worms, early form of, IO3

Yaguarundi, $167 \mathrm{f}$.

Yellow fever:

how driven from Canal Zone, I $85 \mathrm{ff}$.

in Canal Zone, I $79 \mathrm{ff}$.

in days of Spanish explorers, in ${ }^{5}$ Havana, 182,183

successfully treated by Americans, 9 








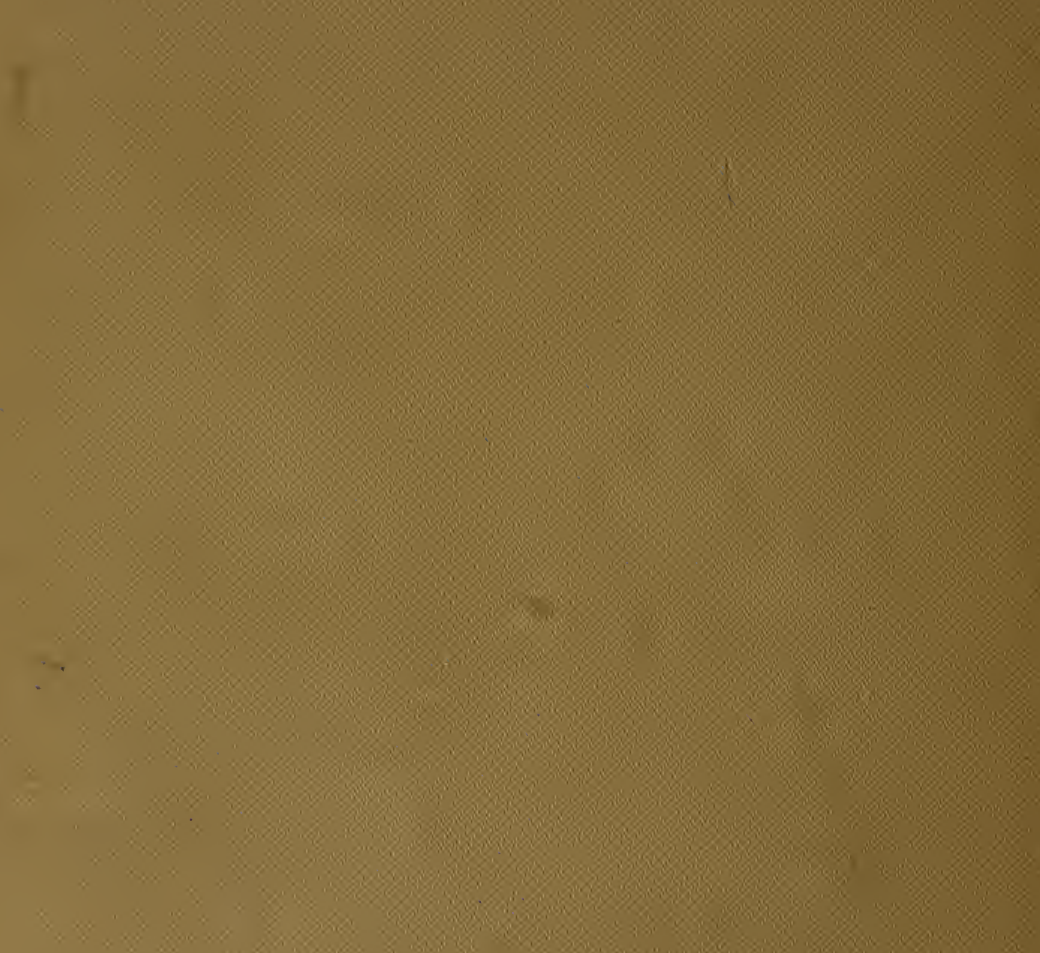

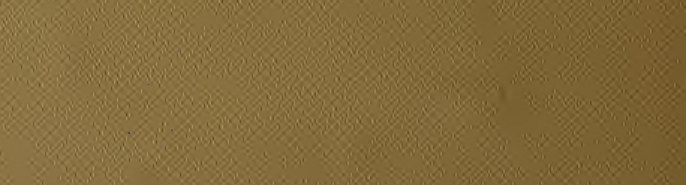

